\title{
Bibliography of fire effects and related literature applicable to the ecosystems and species of Wisconsin. No. 1871995
}

Henderson, Richard A.; Statz, Sandra H.

Madison, Wisconsin: Wisconsin Department of Natural Resources, 1995

https://digital.library.wisc.edu/1711.dl/4H3LX3MRQKMBC8F

http://rightsstatements.org/vocab/InC/1.0/

For information on re-use see:

http://digital.library.wisc.edu/1711.dl/Copyright

The libraries provide public access to a wide range of material, including online exhibits, digitized collections, archival finding aids, our catalog, online articles, and a growing range of materials in many media.

When possible, we provide rights information in catalog records, finding aids, and other metadata that accompanies collections or items. However, it is always the user's obligation to evaluate copyright and rights issues in light of their own use. 
BIOLOGY LIBRARY,

UW/1 A JM9461

430 LINCOLN DR.

INTER DEPT. MAIL

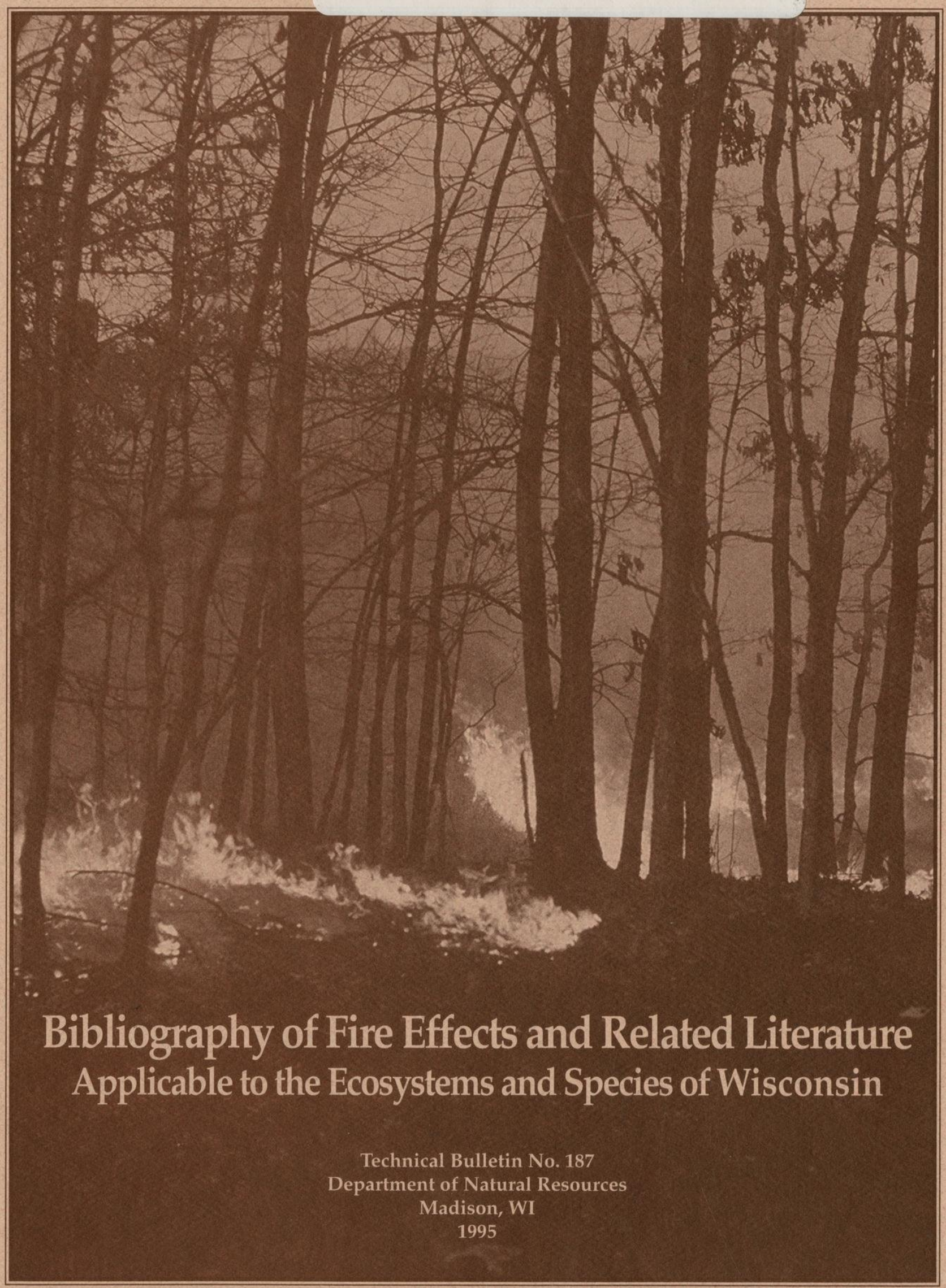


Cover: Night-time fire moving through an oak woodland at The Nature Conservancy's Summarton Bog Preserve. Photo by R. Henderson.

\section{ABSTRACT}

This bibliography provides 841 literature citations pertinent to the effects of fire and its prescribed use on the ecosystems and species of Wisconsin and the upper Midwest. Three separate subject indexes are provided: one for general topics, one for species ( 165 headings), and one for geographic location by state or province ( 51 headings). The general index is divided into 8 broad subject categories, under which there are 28 topic and 58 subtopic headings. The largest subject category, and the main focus of this publication, is Effects of Fire (on soil, water, air, biota, etc.) with 11 topic headings, 41 subtopic headings, and 706 citations. The other categories are Behavior of Fire ( 2 topics, 5 subtopics, 78 total citations), History of Fire ( 4 topics, 129 total citations), Effects of Fire Regimes ( 6 topics, 12 subtopics, 87 total citations), Drought and Fire Interactions (5 citations), Fire Policy (12 citations), Conducting Prescribed Burns ( 2 topics, 11 total citations), and Other Fire Related Management (2 topics, 54 total citations). Also included is a brief and very general overview of the role of fire in Wisconsin and its effects on the ecosystems and species of the state.

Key Words: Wisconsin, Midwest, fire effects, fire behavior, fire history, water, air, soil, plants, animals, communities, litter, nutrient cycles, micro-climate, habitat, grasslands, prairies, barrens, savannas, forests, wetlands, prescribed burns. 
Bibliography of Fire EFFECTS AND RELATEd Literature Applicable to the Ecosystems and Species of Wisconsin

By Richard A. Henderson and Sandra H. Statz

Technical Bulletin No. 187

Department of Natural Resources

P.O. Box 7921

Madison, Wisconsin 53707

1995

\section{CONTENTS}

\section{INTRODUCTION}

4 HOW TO USE THIS BIBLIOGRAPHY

\section{METHODS OF COMPILATION}

4 OVERVIEW OF FIRE EFFECTS IN WISCONSIN

7 GENERAL SUBJECT INDEX

Drought/Fire Interactions, 7

Fire Behavior, 7

Fire Effects, 7

Air Quality, 7

Animals, 7

Communities (grasslands, forests, etc.), 8

Evolution, 9

Habitat (animal food and shelter), 9

Litter (dead plant material), 9

Micro-climate, 10

Nutrient Cycling, 10

Plants, 10

Soil, 11

Water Quality, 11

Fire History, 11

Fire Policy, 11

Fire Regimes (effects of), 11

Other Management Related to Fire, 12

Prescribed Burning, 12

\section{SPECIES INDEX}

Plants, 13

Invertebrates, 16

Reptiles and Amphibians, 16

Birds, 16

Small Mammals, 17

Large Mammals, 17

18 GEOGRAPHIC INDEX

19 LITERATURE CITATIONS 
A prescribed burn to control eastern red cedar invading dry bluff prairie at The Nature Conservancy's Spring Green Preserve (April 1980).

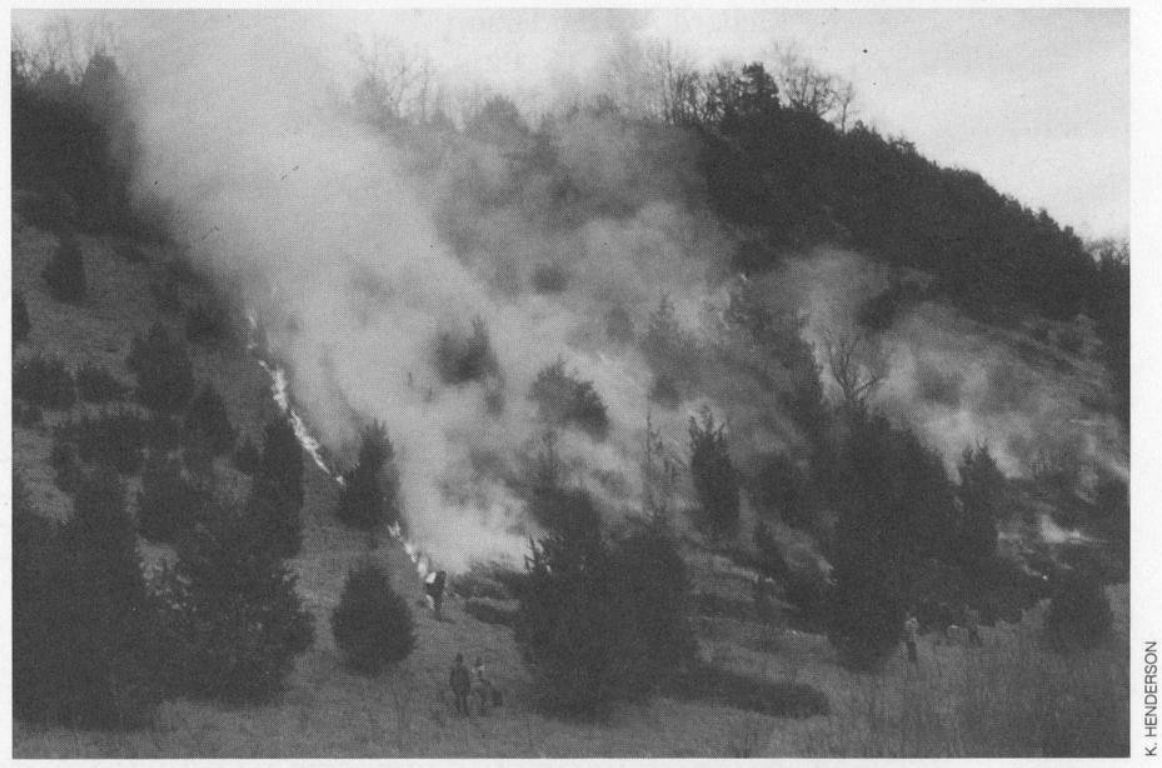

Prescribed fire to clear logging slash in preparation for tree planting.

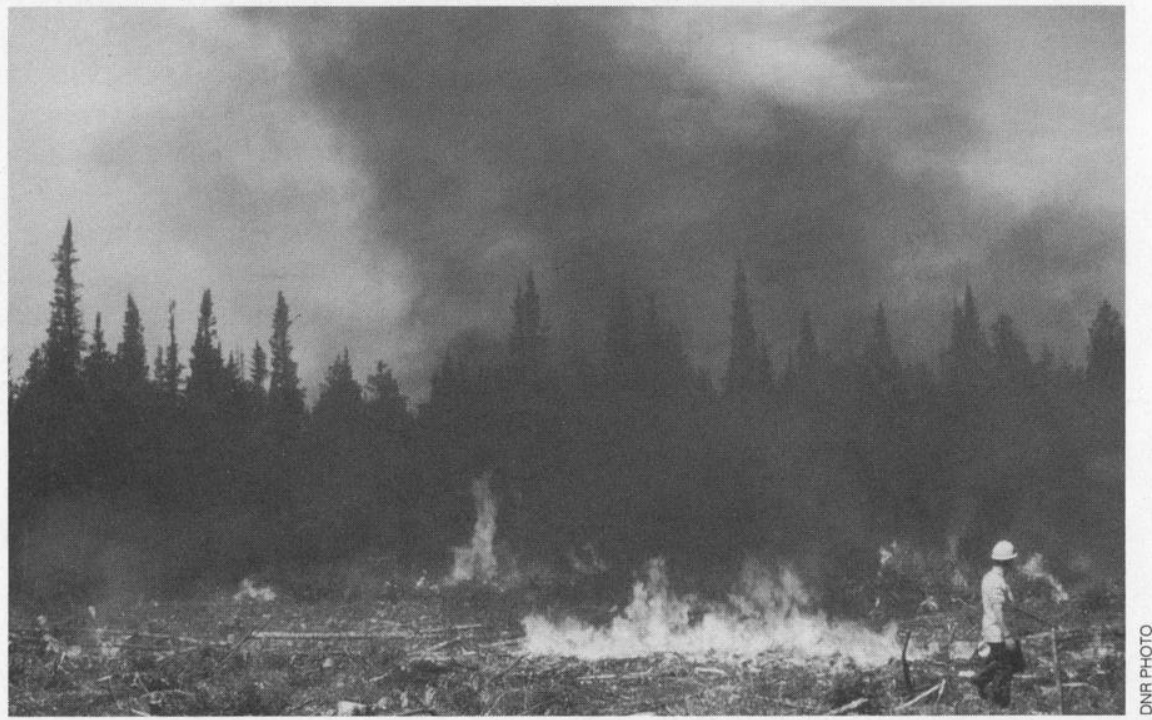

Starting a prescribed fire in a sedge meadow community at South Waubesa Wetlands State Natural Area (April 1990).

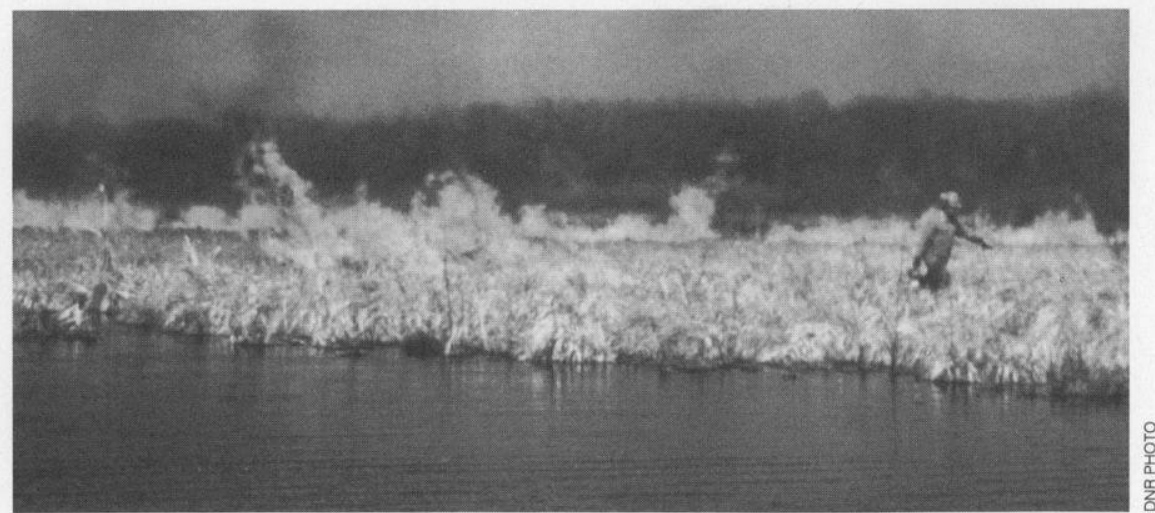




\section{INTRODUCTION}

Fire has long played a major role in modifying and maintaining plant communities in North America (Kozlowski and Ahlgren 1974', Swain 1973 and 1978, Pyne 1983, Gajewski et al. 1985, Backman 1988, Anderson 1990), including much of what is now the State of Wisconsin. In fact, for the past 5 to 6 thousand years (or at least up until European settlers disrupted prevailing fire regimes), half of the state has been covered by fire-dependent communities such as prairies, southern sedge meadows, oak and pine savannas, and oak and pine woodlands (Curtis 1959, Swain 1978, Winkler 1985 and 1986).

Prior to European settlement, fire in North America was caused by both lightning and Native Americans. Fire was probably a major influence on the landscape long before human arrival. Fossil records suggest that fire began to play an important role in central and eastern North America around 25 to 30 million years ago. At that time, the climate apparently became drier, and plant species that depend upon (or at least tolerate) a combination of grazing, drought, and fire, such as oak and grass species, experienced prolific species radiation as savannas and grasslands began to dominate large regions (Barry and Spicer $1987^{2}$ ).

Indigenous peoples most likely increased fire's influence on the landscape, at least in the Northeast, where lightning-induced fire was less common than in the West or in the Southeast (Komarek 1964, 1967, 1968, and 1974, Barden and Woods 1974, Higgins 1984, U. S. Forest Service 1987). Although direct proof of intentional burning of the landscape by early peoples is unattainable by nature, archaeological evidence and ecological evidence suggest that Native Americans actively managed the land with fire for hundreds, if not thousands, of years (Grimm 1984, Patterson and Sassaman 1988, Dorney and Dorney 1989, Denevan 1992). Native Americans likely used fire to enhance production of game, roots, nuts, and berries, and to make their own movement across land easier (Lewis 1980, Pyne 1983). Today fire, in the form of prescribed burns, is used frequently as a management tool. This is not only because of its historical role in maintaining and influencing native ecosystems, but also its low cost relative to other habitat management tools.

In Wisconsin, an estimated 12 to 22 thousand acres are purposefully burned under prescription annually. These burns are conducted by a wide variety of agencies and groups, including the Wisconsin Department of Natural Resources (70\%); private conservation groups and individuals (15\%); federal agencies-U.S. Fish and Wildlife Service, U.S. Forest Service, and National Park Service$(10 \%)$; county and municipal parks (3\%); and the University of Wisconsin System (2\%) (Henderson, unpublished data). The amount of prescribed burning done today is small compared with the hundreds of thousands, if not millions, of acres that probably burned on average each year in the state prior to European contact.

The primary purposes of today's prescribed burns are to (1) maintain (or create) wildlife habitat for game and non-game animals, such as grassland songbirds, prairie grouse, ducks, ring-necked pheasant, wild turkey, ornate box turtle, glass lizard, etc., and (2) maintain (or restore) native plant communities such as prairies, sedge meadows, oak and pine savannas (barrens), and oak woodlands. To a far lesser degree, burns are also conducted to prepare planting sites and to reduce fire hazard.

Fire is a flexible management tool that permits the outcome of a burn regime to be manipulated to fit the ecosystem, species, and management goals at hand. Burn regimes have 3 main variables that determine effects on resources: seasonal timing, frequency, and intensity of the fire(s). These variables are within the control of managers. Therefore, it is very important that managers have knowledge and information about how these variables relate to fire effects. This knowledge enables them to prescribe effective burn regimes to achieve the desired results without incurring negative side effects (such as unintentional loss of species or escaped fire). Unfortunately, our knowledge of fire effects as they relate to the variables of seasonal timing, burn frequency, and fire intensity is far from complete, and the information that is available is often buried in the literature, inaccessible to the average land manager.

We hope this publication will provide a step toward bridging this gap between information and managers. Our intent is to make it easier for land managers to access information on specific fire effects that are applicable to the species and ecosystems of Wisconsin.

We are publishing this bibliography and its indexes now to avoid further delay in making the information accessible. However, we hope to eventually produce a more refined and complete bibliographic index that will be electronically accessible and searchable by managers and researchers statewide.

\footnotetext{
${ }^{1}$ Literature references in the Introduction are found in the list of literature citations, unless otherwise noted.

2 Barry, A. T. and R. A. Spicer 1987. The evolution and paleobiology of land plants. Croom Helm, London. 309 pp.
} 


\section{How to Use This Bibliography}

This bibliography has 841 references and is organized into 3 companion indices: one of general topics, one of species, and one of geographic location by state or province of fire effects information or research. The articles and publications in the bibliography are arranged in alphabetical order by author and are numbered sequentially. These numbers are used in the indexes to match references with subject categories. (Note: Cross-reference indexing is not complete. Often only the primary subjects of a reference are adequately indexed. For example, all references with information about species $X^{\prime}$ 's response to fire are not necessarily listed under species $\mathrm{X}$, but all references with species $\mathrm{X}$ as a major subject of the study are listed under that species.)

\section{Methods of Compilation}

This bibliography was built from a card file begun by the senior author in 1978. Beginning in 1985, this file was kept updated with regular use of both Current Contents and Wildlife Review. ${ }^{3}$ The subject categories of fire(s), wildfire(s), and burn(s)(ing) were routinely reviewed. In 1990, updating from Current Contents became electronic when it became available on disk. This made it possible to review not only keywords, but also titles and abstracts.

In 1989, the file was augmented with citations from a literature collection on fire effects compiled by the Department of Natural Resources' Prescribed Burn and Fire Effects Committee. In 1992, the file was augmented further with the published proceedings from (1) a 1986 symposium, "Prescribed Fire in the Midwest", held at University of WisconsinStevens Point; (2) all biennial North American Prairie Conferences, 1968-90 and (3) all Tall Timbers Fire Ecology Conferences, 1962-89. Chapters or articles from major literature review books on fire effects, such as Kozlowski and Ahlgren (1974), Wali (1975), Wright and Bailey (1982), Chandler et al. (1983), and Collins and Wallace (1990) were also included.

Subject indexing was accomplished by first establishing an outline of categories and cascading subcategories. Standard terms were then adopted as headings for each category and used as the keywords. All articles were then lightly reviewed for subject content and all applicable keywords were assigned. A few reviews were limited to abstracts only. The subject (keyword) outline was refined as the indexing proceeded. Pro-Cite was the software used for managing the citations and their keywords.

\section{Overview of Fire Effects in Wisconsin}

Although information on fire effects in the Midwest is far from complete, enough is known to draw some general conclusions and to predict, with moderate accuracy, the impacts of a given burn. What we do know is that ecological responses to fire can vary greatly due to the influence of many variables, such as vegetation type, specific plant and animal adaptations, fire history, soils, climate, and current fire regime.

Of all these variables, fire regime is the only one over which managers have much control, but it is also one of the more important in determining long-term outcomes. Fire regimes have 4 primary variables; (1) seasonal timing, (2) frequency, (3) heat intensity, and (4) heat duration. The last 2, heat intensity and heat duration, are often lumped together into one variable that is often referred to as intensity. Selecting target values for these variables in burn-planning are some of the most important decisions a manager makes in prescribing fire, the most important being whether or not to burn the site at all.

Species responses to fire are never entirely positive nor entirely negative; there are always some species harmed, some benefitted, and some unaffected by any given fire. In very general terms, ecosystems, communities, or species historically dependent upon fire for their existence or dominance benefit from prescribed burns under the right conditions. In Wisconsin these communities include prairie, sedge meadow, oak savanna, pine barren, pine forest, and most oak forest types. These communities are not all equally dependent upon fire, however. Frequent burning, for example, usually results in prairies and meadows, whereas the forests are sustained by less frequent, or at least less intense, fires. Conversely, ecosystems, communities, or species not historically dependent upon fire do not generally benefit from fire. In fact, fire may damage or alter them so severely that recovery may take centuries. In Wisconsin these communities include the various mesic and wet forest types, and most sphagnum bog types.

Any evaluation of burn regimes should take into account effects of other factors, such as climate, herbivory, and their interactions with each other and fire. Unfortunately, species adaptations to fire can not be easily separated from adaptations to grazing or drought stress; therefore it is often difficult to distinguish among the influences these forces have on vegetation. To complicate the situation

\footnotetext{
${ }_{3}^{3}$ Current Contents: Agriculture, Biology \& Environmental Sciences, published by the Institute for Scientific Information, and Wildife Review, published by the National Biological Survey, are both available electronically at most academic libraries and at the DNR Research Library.
} 
further, these forces are not necessarily independent of each other. Fire is often associated with periodic drought, and there is sometimes an interaction between fire and grazing by large herbivores. For example, recently burned grasslands often attract grazers, and recently grazed areas usually resist fire until dead litter re-accumulates (Steuter 1988, Vinton et al. 1993). This means that any discussion of fire effects, at least from a historical perspective, must incorporate the potential influences of grazing and drought as well. Unfortunately, research that synthesizes this type of information is rare.

Although there is no doubt that grazing and browsing have historically played some role in affecting vegetation structure, it is unlikely, that herbivory played the dominant role in determining vegetation structure here in Wisconsin. There is compelling evidence that fire, facilitated by climate, was the overriding force on the landscape in southern and western Wisconsin and much of the upper Midwest. The juxtaposition of various native plant communities on the landscape, ranging from fire-dependent to fire-intolerant communities, in relation to natural fire breaks and prevailing winds during fire-prone conditions amply demonstrates this point. In addition, the body of evidence from sediment cores, tree fire-scars, and historical accounts (see citations under Fire History in the index) builds a compelling argument for fire's dominant influence.

The following generalizations of species and ecosystem responses to fire in Wisconsin represent the senior author's perceptions, derived from a synthesis of the literature and 18 years of field experience with fire and fire effects. They are intended anly as an introduction to the topic, not as citable conclusions of any particular research. These summaries apply only to fire-dependent or firetolerant ecosystems of Wisconsin and are sometimes handicapped by a scarcity of published data. Also, keep in mind that there are often exceptions to the rules, and the responses referred to are

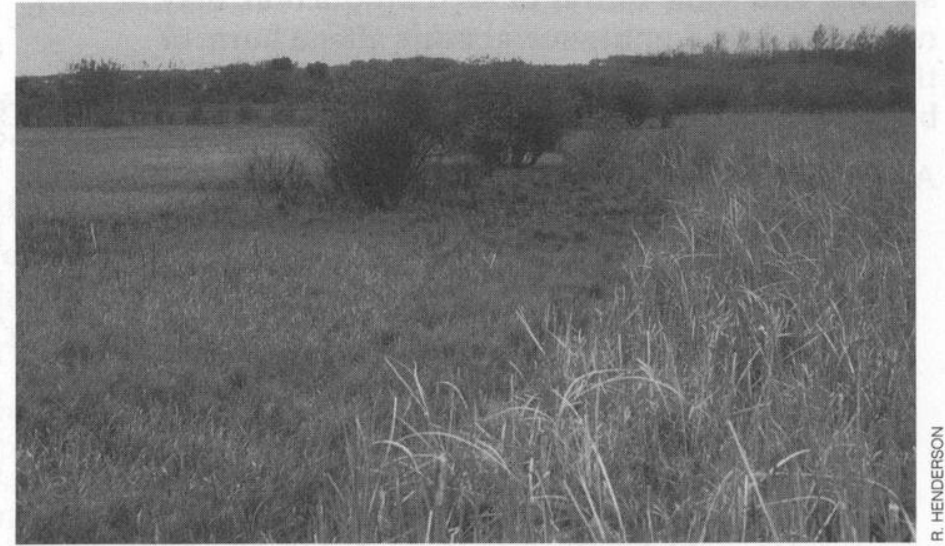

The left half of this photo shows the litter removal, shrub kill-back, and advanced green-up in a sedge meadow resulting from an early spring burn. Right half is unburned.

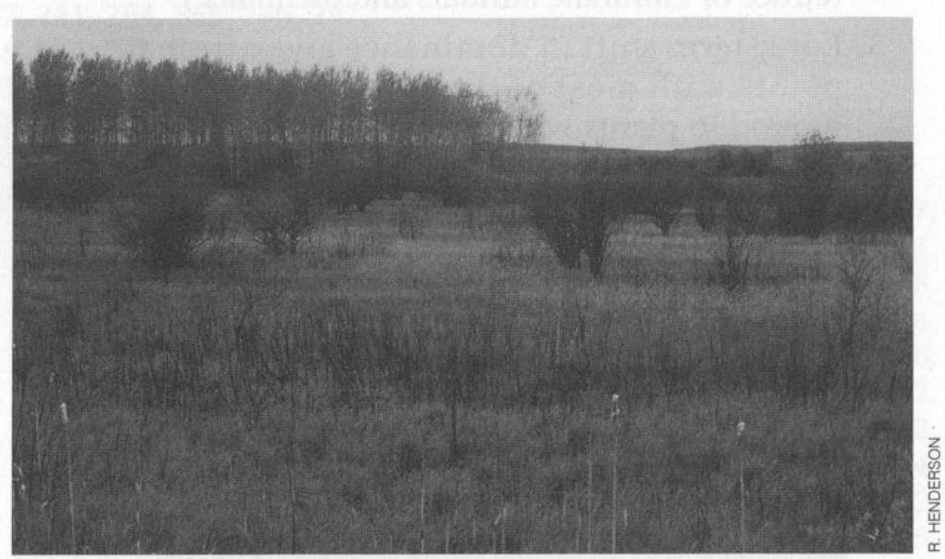

A sedge meadow in June showing the kill-back of shrubs caused by a fire 2 months earlier.

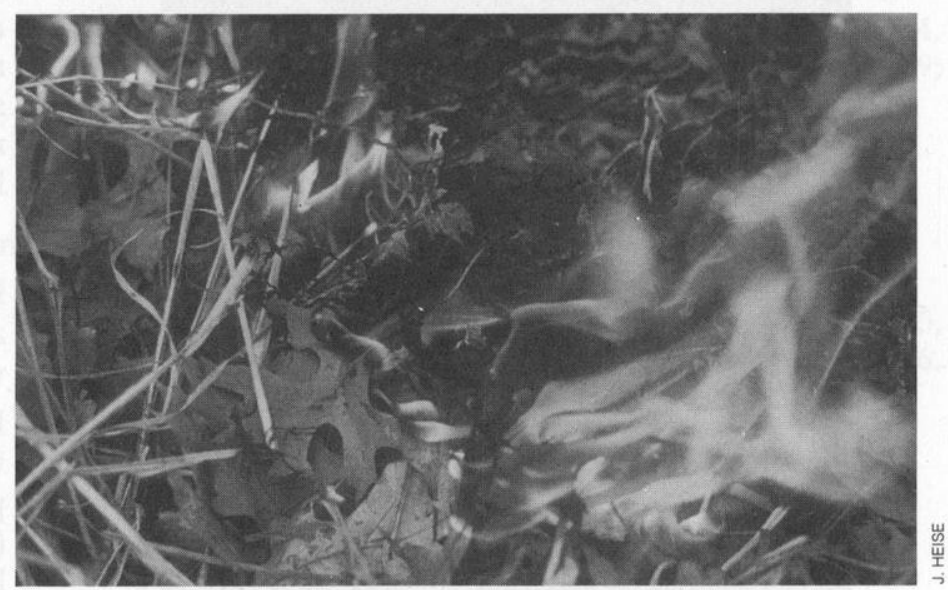

A low-intensity back-fire in oak savanna ground litter. 
not always expressed in the first post-fire season. In fact, many responses, such as tree mortality, changes in soil fertility, population changes of long-lived species, and some flower or seed production, may not be expressed until several years after a burn, or they may require repeated burns for many years before they become evident.

A. Fire Effects on Vegetation:

1. Increase in species diversity, both richness and equity of species representation. (However, fire intolerant species, such as some woodland spring ephemerals, may be lost; vulnerability varies with the timing of the burn.)

2. Short-term increase in annual and biennial species (e.g., ragweed [Ambrosia artemisiifolia and $A$. trifida] and sweet clover [Melilotus alba and M. officinalis]), but normally not at the long-term expense of perennials. (However, fires at certain times of the year can actually reduce or eliminate annuals and biennials.)

3. Long-term shift in dominance away from plants with most of their biomass above ground to plants with most of their biomass below ground.

4. Increase in flower, seed, fruit, or nut production (as much as 10 fold in some exceptional cases).

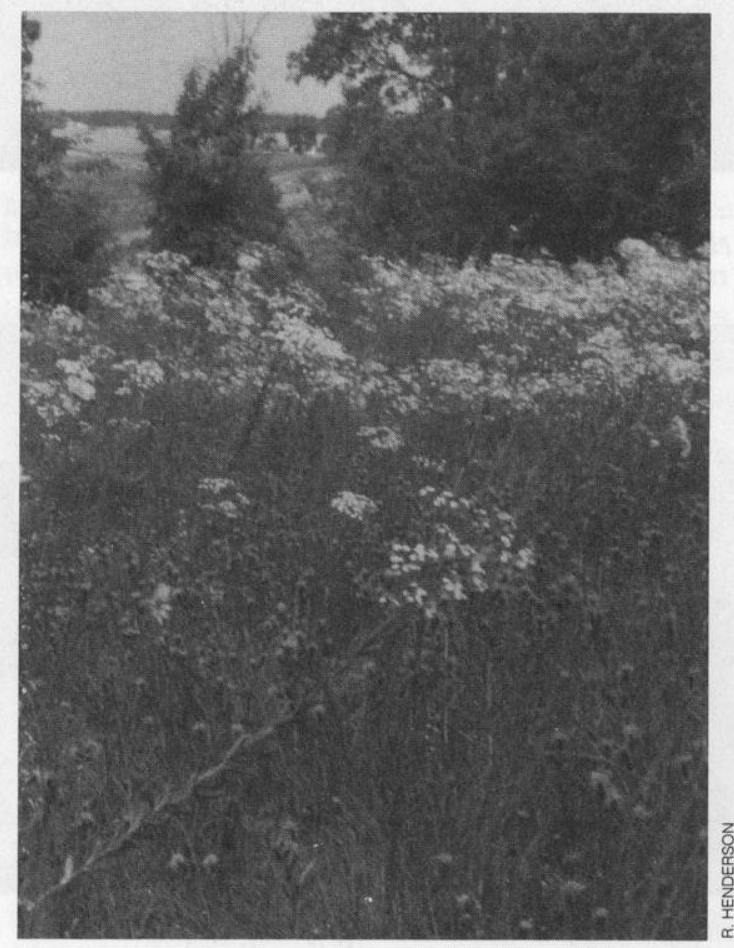

An increase in flowering resulting from fire in prairie.
5. Increase in biomass (forage) production both above and below ground for one or more years. (This is especially true in native prairie.)

6. Improved forage quality, both in nutrition and palatability.

B. Fire Effects on Animals:

1. Initial drop in numbers and species. (This results from some mortality among invertebrates, reptiles, and small mammals-but rarely birds and large mammals - and some emigration of litter-dependent birds and mammals. A notable exception to this initial-reduction rule of thumb is the immediate increase in the use of burned areas by many foraging and hunting species-especially birds - drawn by more favorable foraging conditions.)

2. Eventual increase in animal numbers and species that meets or exceeds pre-burn levels. (This increase may occur within months or it may take several years. It is generally the result of increased primary and secondary productivity and the consequential ripple effect up through the food chain, improved habitat structure, or both.)

3. Should a species be totally removed or driven out from a given site by the effects of a fire, it will recover on that site only if individuals from another site are close enough to recolonize. Dispersal distance varies by species. The effective dispersal distance of some insects ranges from less than 100 feet to several miles. Birds, on the other hand, recolonize readily over distances of dozens to hundreds of miles. (Unfortunately, it is not well documented which species fall into this "need to recolonize" category. Some habitat-specialist insects-such as those restricted to prairie or other remnants of native vegetation-may be among them. If so, potential presence of these species requires caution when using fire, such as leaving viable "refuge" areas unburned.)

C. Fire Effects on Soil:

1. Reduction of litter, duff, and humus layers above the mineral soil surface resulting in warmer soil temperatures.

2. Increase in fertility and organic matter within the mineral soil resulting from increased plant root and soil micro-organism activity. (This can result in significant permanent carbon storage that may be capable of reducing atmospheric $\mathrm{CO}_{2}$ levels in the long run.) 


\section{DROUGHT/FIRE \\ INTERACTIONS}

$325,404,405,467,662$

\section{FIRE BEHAVIOR $>$ MONITORING}

Fire spread

60, 131, 190, 251, 371, 611, 661, $669,674,688,691,697,737,815$, 834

\section{Fire temperature}

$43,48,50,68,131,155,223,242$, $265,314,361,481,513,529,588$, $602,661,669,688,691,694,834$

\section{Fire weather}

$79,80,131,164,252,260,314$, $371,381,416,467,490,591,611$, $661,697,772$

\section{Fuel}

$48,50,80,98,99,113,131,136$, $145,148,164,190,223,251,260$ $314,381,479,481,490,568,611$, $674,688,694,697,720,737,772$, 792,834

Smoke

$367,486,602$

\section{MODELING}

$52,145,153,187,236,356,462,490$, $509,519,588,592,593,629,658$, $674,702,748,750,816$

\section{FIRE EFFECTS \\ $\triangle$ AIR QUALITY}

\section{Particulates}

$95,128,151,234,257,261,365$, $366,367,420,423,425,454,538$, $581,621,633,717,777,778$

\section{Chemistry}

$151,152,165,180,234,366,367$ $420,454,581,621,626,717,718$, 753,777
Miscellaneous

$541,570,772$

\section{$\triangle$ ANIMALS}

Macro-invertebrates

Oligochaetes (Earthworms)

$362,364,596$

Arachnids

(Spiders, Ticks, Mites)

214, 485, 525, 596, 598, 744, 781,782

\section{Insects}

$17,29,34,42,54,76,77,88,90$, $120,121,124,130,169,179$, $182,183,214,229,230,231$, 237, 241, 254, 255, 296, 297, $338,344,345,476,491,494$, 495, 508, 520, 525, 532, 539, $548,580,596,630,631,643$, 651, 696, 701, 744, 776, 781, 825,835

Prairie

$29,34,77,90,121,124$, $130,179,182,183,229$ $230,231,237,338,491$, $539,548,580,596,643$, $651,701,744$

Savanna/barren 120, 525, 696

Forest

$54,255,344,345,476,835$

Coleoptera (Beetles) 34, 54, 121, 255, 344, 345, $476,631,643,696$

Diptera

(Flies and Mosquitoes)

$34,90,776$

Hemiptera (True bugs) $34,124,631$

Homoptera (Leafhoppers, Treehoppers, and Spittlebugs) 124,651
Hymenoptera

(Ants, Wasps, and Bees) $34,76,476$

Lepidoptera

(Moths and Butterflies)

$169,179,183,495,701$

Orthoptera (Grasshoppers and Crickets) $34,88,229,230,231,580$

Chilopods (Centipedes) 596

Diplopods (Millipedes) 596

\section{Herptiles}

(Reptiles and Amphibians)

228, 397, 472, 503, 515, 516, 517

\section{Birds}

$38,39,40,67,71,78,80,86,87$, $103,104,123,130,133,138,161$, $178,188,207,216,220,221,228$, 238, 250, 270, 279, 292, 293, 334, $338,348,350,357,359,375,376$, $379,380,397,398,399,409,412$, $426,431,459,468,472,507,522$, $526,545,559,566,575,586,594$, $606,607,608,615,619,636,652$, $655,670,673,677,686,700,705$, $762,765,780,789,795,796,804$, $805,825,834,840,841$

Prairie

$80,130,228,279,292,334$, $338,350,375,398,399,409$, $431,459,575,795,796$

Savanna/Barren $40,78,221,559,670$

Forest

$38,39,71,133,178,348,545$, $559,606,607,608,670,686$, 789,834 


\section{GENERAL SUBJECT INDEX (continued)}

\author{
Small Mammals \\ $64,67,118,133,140,141,142$, \\ $162,171,211,228,238,285,293$, \\ $294,338,382,383,384,385,395$, \\ $397,472,507,532,559,569,582$, \\ $639,640,675,678,679,680,684$, \\ $723,743,780,789,791,834$
}

\section{Prairie}

$141,142,211,228,338,382$, $383,384,385,569,639,640$, $675,678,679,680,743$

Savanna/Barren

$64,559,723$

Forest

$118,133,559,789,834$

\section{Large Mammals}

$67,71,133,166,167,178,201$, 206, 228, 259, 276, 288, 294, 338, $358,378,394,396,397,399,401$, 410, 446, 447, 458, 472, 473, 474, $482,507,558,559,573,601,632$, $656,662,690,708,731,741,745$, $751,754,770,788,804,828,829$, 834

Prairie

$166,228,338,399,656,690$, 754

Savanna/Barren

559,770 .

Forest

$71,133,178,446,447,559$, $632,656,788,829,834$

\section{COMMUNITIES}

\section{Grasslands}

General

$24,42,48,66,87,88,107,130$, $162,169,171,181,214,215$, $222,238,265,273,286,292$, $293,296,297,298,314,346$, $361,379,380,409,425,429$, $444,474511,527,534,559$, $566,594,599,603,618,619$, $622,627,630,673,684,707$, $727,739,758,767,769,781$, $795,796,803,805,812,815$, $830,832,834$
Old Field

$496,528,529,532,537,716$, $804,818,838$

\section{Pasture}

$27,226,328,392,498,499$, $537,544,564,604,791$

Prairie, shortgrass

$274,333,336,337,338,441$, $442,443,506,833$

Prairie, midgrass

$1,23,47,49,50,82,157,158$, 191, 203, 225, 256, 257, 333, $334,336,337,338,350,382$, $398,399,431,441,442,491$, $521,524,575,580,587,600$, $609,628,656,678,679,689$, $690,694,799,817,831,833$, 839

Prairie, tallgrass

$5,10,11,13,14,19,21,25,26$, $27,28,29,34,37,43,48,69,70$, $75,77,80,84,90,97,98,101$, $102,106,108,121,124,141$, $142,156,158,159,174,179$, $182,183,197,204,208,211$, $217,218,219,223,224,228$, $229,230,231,233,257,262$, $263,264,265,266,267,271$ $272,274,275,284,290,305$, $310,311,312,317,319,320$, $324,325,326,328,329,338$, $339,340,347,349,351,352$, $353,354,362,363,375,382$, $383,384,385,391,392,393$, $399,403,404,405,406,407$, $408,411,432,433,434,435$ $436,449,459,469,470,471$ $483,484,498,499,533,535$, $539,542,543,544,548,557$, $560,561,562,569,595,596$, $597,598,600,639,640,642$, $643,644,645,646,647,648$, $649,650,651,667,675,676$ $680,701,709,710,711,712$ $734,743,744,754,755,760$, $775,782,783,808,809,833$

Illinois $28,34,197,391$, $535,596,639,640,642$

Indiana 211
Iowa $19,217,218,219$ $339,411,557,597$

Kansas 5, 10, 11, 21, 25, 26, $27,43,77,97,101,102,106$ $124,141,142,208,229,263$, $264,265,267,274,284,328$ $347,351,354,383,384,385$ $403,404,405,406,407,499$ $542,544,569,644,667,734$ 754,755

Minnesota $179,182,183$, $375,562,675,709,710,744$

Missouri 329, 411, 432, $433,434,435,436,676$

Nebraska $69,228,483,484$

North Dakota 290, 399

Oklahoma $13,14,80,90$, 223, 224, 233, 392, 595

\section{South Dakota 84}

Wisconsin 29, 108, 204, $319,324,325,326,459$, $469,470,471,560,561$, $598,760,808$

\section{Savannas}

General

33, 78, 333, 429, 559, 696, 738, 748

Aspen Parkland $23,47,50,51,113,188,189$, $386,669,710$

\section{Oak Barren}

$44,46,64,89,155,184,282$, $318,487,641,760,761,770$, 800

Illinois 641

Indiana $46,155,318$

Minnesota $44,184,800$

New Jersey 89,487

Wisconsin $760,761,770$ 


\section{Oak Savanna}

$32,35,36,40,116,209,272$, $289,295,321,322,323,324$, $355,372,373,400,492,525$, $546,549,623,670,703,723$, $724,798,800,801$

\section{Pine Barren}

7, 9, 89, 120, 172, 221, 455, $487,488,489,613,661,666$, $687,726,764,819$

\section{Florida 221}

Michigan 7,9,661

New Jersey $89,120,172$, $455,487,488,489,819$

\section{Wisconsin 764}

\section{Forests}

\section{General}

$16,18,33,45,48,71,125,131$, $168,186,200,235,247,251$, $302,304,314,342,425,428$, $429,456,457,500,527,552$, $559,583,602,681,686,702$, $720,721,730,756,827,829$, 834
Aspen Forest

$785,786,788$

Boreal Forest

$39,53,72,73,118,151,194$, 198, 202, 249, 280, 313, 315, $316,344,345,370,555,632$, $660,666,682,683,706,740$, 789

Gallery Forest

$4,6,102,656$

\section{Hardwood Forest}

$57,93,110,122,133,178,193$, $243,244,245,246,271,283$, $300,301,306,400,422,477$, $485,547,556,565,634,635$, $654,659,685,704,715,716$, $732,746,779,807,813,814$

Old growth

$147,327,554$

Hemlock Forest

$244,246,685$

Mixed

Conifer/Hardwood Forest 148,715

\section{Oak Forest}

$8,12,22,32,119,126,155,185$, $245,281,318,373,377,400$, $430,461,462,463,465,466$, $530,531,545,589,590,605$, $606,607,608,612,623,670$, $703,716,749,793,807,810$, $813,814,835,836$

\section{Pine Forest}

$20,24,38,56,60,65,74,81,96$, $115,117,255,268,309,316$, $331,348,422,439,445,446$, $447,451,476,502,536,547$ $571,614,634,635,661,666$ $697,719,728,771,773,784$, $787,802,806,807,810$

Florida 502

Georgia 117,451

Michigan 547, 634, 635, 661, 807

Minnesota 20,38

South Carolina 81

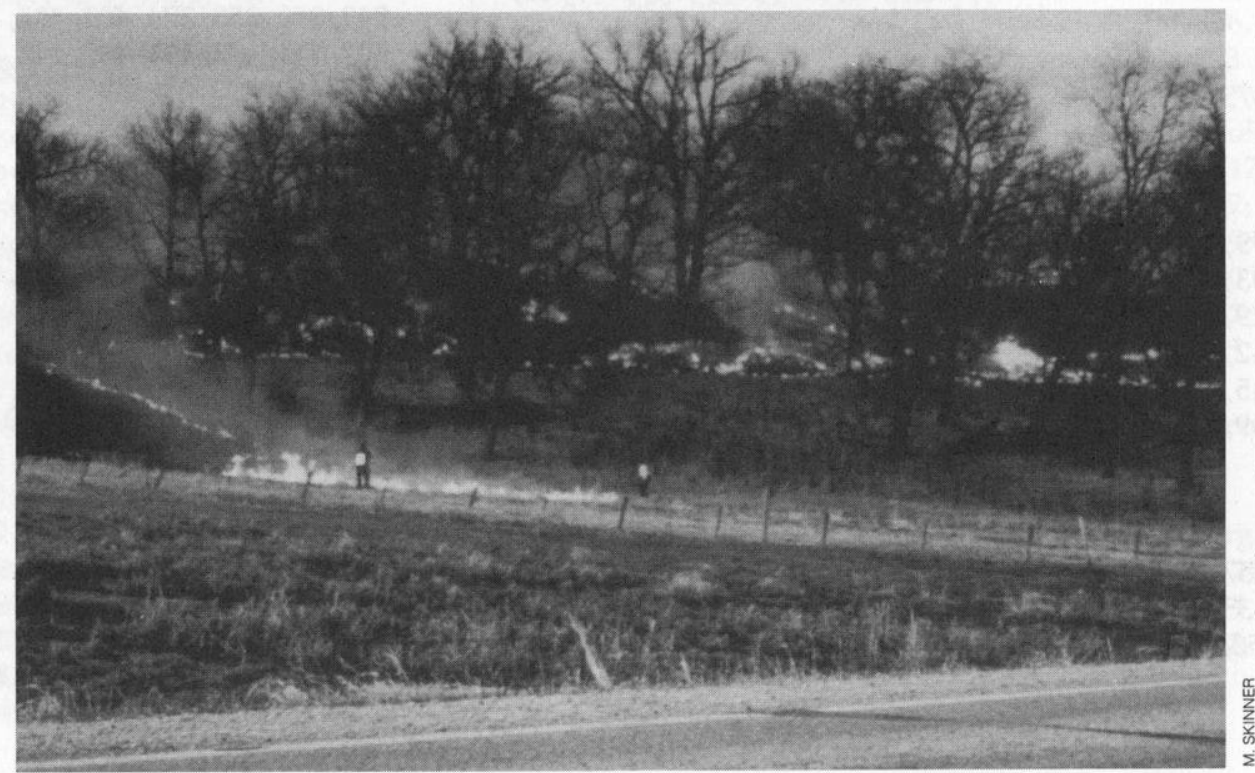

A prescribed burn of an oak savanna at dusk. 


\section{Wetlands}

General

$3,48,58,177,308,314,330$, $338,380,397,448,527,559$, $563,636,637,638,671,672$, $729,759,765,776,834,841$

\section{Cattail Marsh}

$55,523,763,780,790$

Fen
360
Sedge Meadow
763

\section{$\triangle$ EVOLUTION}

294, 395

\section{$\triangle$ HABITAT}

\section{(see also Animals and Plants)}

$55,67,86,100,103,117,140,161$, $189,201,206,221,276,338,348,350$, $359,375,378,394,410,412,426,439$, $445,446,447,452,468,472,473,494$, $497,507,518,527,545,558,625,636$, $640,655,668,675,677,700,711,726$, $731,745,762,770,780,788,790,804$, 828,829

\section{Food \\ 100, 117, 189, 201, 206, 338, 378, $412,445,446,447,452,473,497$, $507,558,655,668,711,726,731$, $788,828,829$ \\ Shelter \\ $161,338,348,350,375,439,494$, 625}

\section{$\triangle$ LITTER}

$1,15,20,22,29,98,99,134,140$, $147,148,181,187,203,212,217$, $234,257,273,320,329,346,351$, $408,411,434,435,442,457,471$, $479,496,556,595,645,646,648$, $650,666,732,756,769,783,784$, 787,799

\section{Prairie}

1, 29, 98, 203, 217, 257, 320, 329, $351,408,411,434,435,442,471$, $595,645,646,648,650,783,799$

\author{
Savanna/Barren \\ 666
}

\section{Forest}

$20,22,147,148,457,556,666$, $732,756,784,787$

\section{$\triangle$ MICRO-CLIMATE}

$233,353,392,403,528,535,560$, 561,657

\section{Air Temperature \\ $233,392,528$}

Relative Humidity

233

\section{Sunlight}

$353,403,528,560,657$

\section{$\triangle$ NUTRIENT CYCLING}

570,784

\section{$\triangle$ PLANTS}

\section{Algae, terrestrial}

258

\section{Forbs}

$9,13,16,19,46,49,58,76,82,85$, $108,117,159,174,177,182,184$, $185,189,193,217,226,267,280$, $282,293,298,305,312,317,319$, $324,325,338,432,444,451,469$, $480,488,496,504,505,513,530$, $540,543,559,562,571,597,740$, $745,766,789,834$

\section{Flower Production}

$19,69,127,175,211,275,282$, $319,324,326,349,352,353,354$ $407,469,483,562,571,597,616$, 628,712

\section{Grasses and Sedges}

$2,7,10,11,13,19,21,23,29,47$, $49,50,51,69,84,85,100,107$, $108,109,117,134,135,159,174$, $175,177,189,193,195,196,197$ $208,215,217,218,219,223,224$, 225, 226, 256, 257, 267, 273, 291, $293,298,311,319,325,326,330$ $338,349,352,354,391,404,405$, $407,432,433,434,435,436,443$,
$444,451,483,484,497,498,499$ $506,521,524,528,542,543,549$, $559,574,587,595,603,604,618$ $628,634,637,668,707,712,716$ $734,745,754,766,799,802,811$ $812,817,820,830,831,834,838$, 839

\section{Prairie}

$10,11,13,19,21,23,29,47,49$ $50,69,84,108,159,174,196$ $197,208,217,218,219,223$, $224,225,256,257,267,311$, $319,325,326,338,349,352$, $354,391,404,405,407,432$, $433,434,435,436,443,483$, $484,498,499,506,521,524$ $542,543,587,595,628,712$, $734,754,799,817,831,839$

\section{Savanna/Barren}

$7,549,559,766$

Forest

$117,193,451,559,634,716$, 802,834

\section{Growth (biomass,}

vegetative spread, etc.)

$11,13,16,19,25,44,51,62,69$ $70,80,84,85,89,99,108,109$ $111,116,126,154,177,182,184$ 193, 196, 197, 217, 218, 224, 226 , $256,258,270,274,275,282,290$ 291, 301, 305, 311, 319, 320, 330 $349,352,353,374,403,404,406$, $407,411,433,434,437,441,442$, $445,469,473,478,487,496,498$ $499,505,521,528,532,533,535$, $542,560,561,574,587,589,609$ $614,616,628,637,647,649,659$, $661,672,682,689,712,731,754$ $761,767,768,783,786,793,818$ 833,839

\section{Prairie}

$11,13,19,25,69,70,80,84$ $108,182,196,197,217,218$ $224,256,274,275,290,305$ $311,319,320,349,352,353$ $403,404,406,407,411,433$, $434,441,442,469,498,499$ $521,533,535,542,560,561$ $587,609,628,647,649,689$ $712,754,783,833,839$ 
Savanna/Barren

$44,89,116,184,282,487,661$, 761

\section{Forest}

$16,126,147,193,301,327$, $445,554,589,614,659,661$, $682,786,793$

\section{Lichens}

$16,258,496,798$

\section{Mosses \\ 471,496 \\ Physiology \\ 403, 405 \\ Seeds \\ Seed Bank \\ 5, 41, 251, 307, 369, 428, 437, $489,707,797$ \\ Seed Germination \\ $9,16,41,94,134,137,176,273$, $275,280,282,389,390,428$, 437, 438, 480, 513, 540, 578, $616,618,620,707,725,736$ \\ Seed Production $117,126,127,135,182,183$, $218,282,305,437,445,483$, 799}

\section{Seedlings (non-tree) \\ $94,134,275,438,540$}

\section{Shrubs}

$2,6,16,20,23,40,44,46,50,51$, $56,97,101,107,116,193,202$, $215,232,267,323,338,487,488$, $509,513,540,543,571,572,590$, $609,811,819,829$

\section{Species composition (diversity, succession, etc.)}

$7,8,10,12,14,30,33,35,36,39$, $48,66,72,82,89,97,101,106$, $110,112,131,147,149,156,158$, $159,168,170,173,203,213,214$, $221,233,243,244,246,262,266$, $267,271,274,295,306,314,315$, $316,318,325,327,341,356,370$, $372,373,376,419,422,436,440$, $448,450,451,456,463,468,488$, $492,496,510,521,524,532,546$,
$547,559,574,599,603,616,627$, $637,641,676,681,682,685,703$, $706,710,727,738,758,759,760$, $763,764,767,768,769,774,779$, $783,789,807,813,814,832$

\section{Prairie}

$10,14,48,82,97,101,106,156$, $158,159,203,233,262,266$, $267,271,274,325,436,521$, $524,676,710,760,783$

Savanna/Barren

7, 33, 35, 36, 89, 221, 295, 318, $372,373,488,492,546,559$, $641,703,738,760,764,774$

\section{Forest}

$8,12,33,39,48,72,110,131$, $147,168,243,244,246,271$, $306,314,315,316,318,327$, $370,373,422,451,456,463$, $547,559,681,682,685,703$, $706,779,789,807,813,814$

\section{Trees}

$2,3,4,6,7,8,16,32,44,46,47,51$ $59,62,68,74,89,96,97,101,102$, $106,107,111,112,122,126,129$, $137,146,149,154,170,177,189$, 193, 194, 198, 199, 201, 206, 209. 221, 227, 235, 241, 243, 244, 246, $251,254,255,256,257,272,277$, 278, 281, 286, 299, 301, 303, 306, $309,313,316,318,321,322,338$, $343,355,373,374,376,387,444$, $445,461,462,466,473,478,492$, $493,519,531,536,546,547,559$, $565,567,584,585,588,589,590$, $592,612,613,614,623,629,635$, $657,659,661,682,683,684,685$, $687,709,716,720,728,732,740$, $747,751,771,785,786,787,788$, $789,793,800,810,819,820,829$, 834,836

Tree Saplings 227, 321, 322, 430, 565, 605, 716

Tree Seedlings $3,59,102,227,235,281,322$, $374,386,387,430,466,585$, $589,682,683,684,728,732$, 771,836 $\triangleright$ SOIL

\section{Soil Chemistry}

$15,17,20,40,65,81,89,131,132$, $147,181,187,217,219,252,268$, $269,284,310,338,340,353,360$, $392,457,484,495,528,533,534$, $543,544,616,638,645,646,647$, $648,650,663,664,666,687,735$, $749,756,773,787,792,803,818$

\section{Prairie} $217,219,284,310,338,340$, $353,392,484,533,543,544$, $645,646,647,648,650$

\section{Savanna/Barren}

$40,89,663,664,666,687$

Forest

$20,65,81,131,147,268,457$, $666,749,756,773,787$

\section{Soil Erosion}

$205,222,654$

\section{Soil Fungi}

$17,61,70,139,195,197,198,402$, $449,504,583,650,722,752,808$, 809,837

\section{Soil Micro-arthropods}

$17,115,120,470,471,556,644,653$

\section{Soil Microbes}

$17,37,284,329,331,471,534$, $550,556,616,650,664,691,719$, 792,808

\section{Soil Moisture}

$13,15,17,26,131,147,181,191$, $212,217,219,251,257,273,284$, $310,319,351,381,392,403,406$, $471,500,506,521,528,533,543$, $560,587,595,609,645,650,744$, $756,785,832$

\section{Soil Nematodes} 502

\section{Soil Organic Matter}

$20,22,24,40,181,212,251,252$ $381,471,533,534,645,646,650$, $683,728,756$ 


\section{Soil Temperature}

$13,16,43,50,108,132,181,219$, $319,320,353,392,543,544,560$, $595,602,707,756,785,792,832$, 837

\section{$\triangle$ WATER QUALITY}

$205,257,310,368,460,654,733,772$

Water Chemistry

205, 310, 368, 460, 733

Sedimentation/Particulates $205,654,733$

\section{FIRE HISTORY}

\section{$\triangleright$ LIGHTNING}

$57,83,87,333,415,418,419,424$, $688,720,721,742,826$

\section{$\triangleright$ PALEO-ENVIRONMENT/ ECOLOGY}

$8,31,45,150,159,342,413,421$, $440,512,552,660,713,714,789$, $821,822,823,824$

\section{$\triangle$ POST-EUROPEAN SETTLEMENT}

$12,28,53,72,73,83,87,91,92,101$, $148,163,194,227,243,244,248$, $283,289,300,302,318,335,359$, $371,373,388,440,456,464,511$, $538,555,557,576,627,660,692$, $699,704,742,807,826,841$

\section{$\triangle$ PRE-EUROPEAN SETTLEMENT}

$8,28,31,52,53,72,73,83,93,119$, $125,143,144,146,159,170,172$, $173,186,192,200,209,210,240$, $244,245,248,249,271,287,289$, $295,300,315,335,359,371,377$, $388,400,440,450,453,456,464$, $465,477,511,538,553,577,579$, $617,627,693,704,713,714,730$, $760,763,794,806,807,822,823$, 824,833

\section{FIRE POLICY}

$105,114,160,163,165,475,514$, $551,610,624,768,826$

\section{FIRE REGIMES}

(effects of)

\section{FIRE FREQUENCY}

64, 230, 262, 291, 315, 354, 436, 518, $525,623,631,647,724,741,750$, 774,804

\section{$>$ FIRE TIMING (seasonal)}

$69,303,319,324,325,326,334,349$, $393,469,521,537,542,571,688$, $734,774,804,812$

\section{FALL BURNS}

$13,49,252,303,319,325,326,363$, $381,469,499,609,642,688,839$

\section{Fall-annual \\ 326 \\ Fall-periodic \\ 325 \\ Fall-single \\ $13,319,642$}

\section{SPRING BURNS}

$2,25,49,64,80,84,96,99,179,208$, $214,226,252,275,276,303,349$, $350,381,391,441,453,469,483$, $484,499,520,530,542,549,562$, $596,597,609,623,630,678,688$, $705,755,761,811,812,820$

\section{Spring-annual}

$10,11,23,69,76,108,116,117$, $215,262,282,319,321,322,324$, $325,326,329,406,407,432,435$, $471,533,631,645,710,734,744$, 800

Spring-biennial

$215,471,631$

Spring-periodic

$116,262,325$

Spring-single

$69,76,108,282,319,322,744$

\section{SUMMER BURNS}

2, 14, 96, 99, 116, 214, 215, 233, 303, $537,688,774,811$

\section{Summer-annual \\ 116 \\ Summer-biennial \\ 215}

\section{Summer-periodic}

116

\section{WINTER BURNS}

$14,19,58,298,392,451,532,564$, $734,774,820$

\section{Winter-annual \\ 734 \\ Winter-single \\ 19}

\section{OTHER MANAGEMENT RELATED TO FIRE \\ $>$ GRAZING}

$30,42,47,51,66,77,87,97,130$, $138,157,158,166,217,219,232$, $263,264,284,340,341,352,378$, $379,380,444,452,473,564,582$, $599,649,663,665,671,672,676$, $690,754,755$

\section{MOWING}

55, 214, 215, 219, 232, 267, 292, 293 , $341,349,393,557,595,651,676$, $785,786,788,796$

\section{PRESCRIBED BURNING}

\section{ECONOMICS}

$63,75,277,304,309,624$

\section{TRAINING}

$332,486,501,610,772$ 


\section{SPECIES INDEX}

\section{PLANTS}

Abies balsamea (balsam fir) 241

Acer rubrum (red maple) $201,589,659$

Acer saccharum (sugar maple) $147,246,554,659$

\section{Agropyron repens}

(see Elytrigia repens)

Alliaria petiolata (garlic-mustard) 530

Amelanchier sanguinea

(Juneberry, serviceberry) 323

Amorpha canescens (leadplant) $10,319,325,469$

Andropogon (bluestems) 349

\section{Andropogon gerardii}

(big bluestem)

$10,11,19,21,29,69,84,159,175$, $208,217,225,311,326,351,352$, $354,392,405,406,407,433,435$, $436,483,484,498,499,542,560$, $603,712,716,734,754$

Andropogon scoparius

(see Schizachyrium scoparium)

Anemone patens (pasque flower) 23,324

Arceuthobium pusillum (eastern dwarf mistletoe) 247

Betula alleghaniensis (yellow birch) 554

Betula papyrifera (paper birch) $147,243,473,659$

Bouteloua curtipendula (side-oats gramma-grass) $208,326,603$

Bromus inermis (smooth brome) $47,51,84,484,549,812$

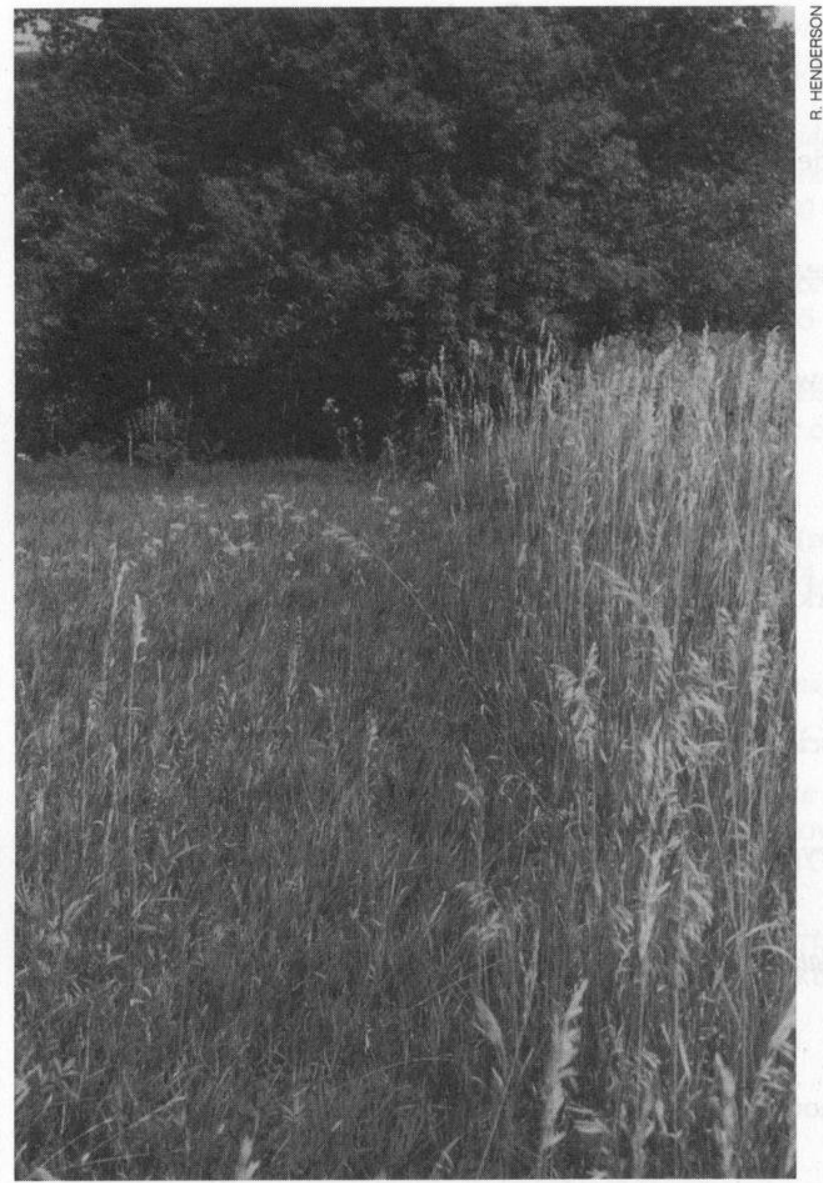

The suppression of the non-native grass smooth brome invading dry prairie. The left half was burned in May. The right was unburned. (photo taken in August)

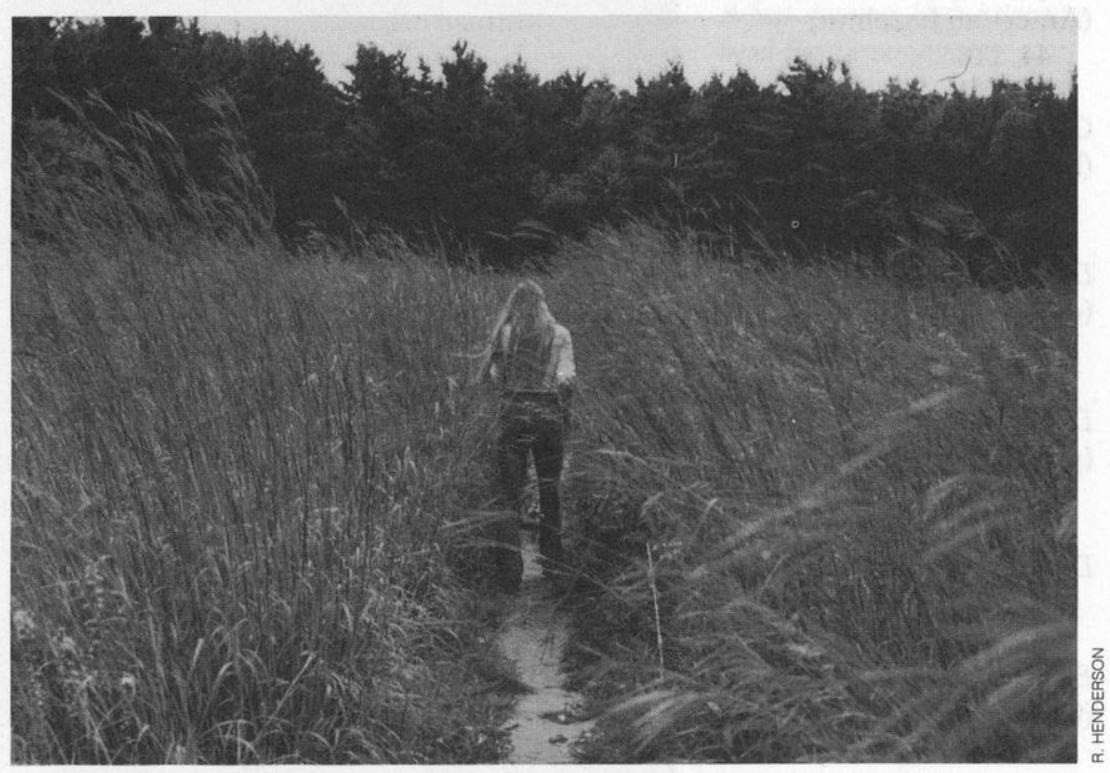

Increase in big bluestem growth and flowering after a spring fire. 


\section{SPECIES INDEX (continued)}

\section{Bromus japonicus \\ (Japanese brome) 799}

Bromus kalmii (prairie brome) 326

Bromus secalinus (cheat-grass) 338

Bromus tectorum (downy chess) 506

Carya (hickory) 461, 793

Carya ovata (shagbark hickory) 209

\section{Cassia fasciculata \\ (see Chamaecrista fasciculata) \\ Ceanothus \\ (red root, New Jersey tea) 540,578}

Chamaecrista fasciculata (partridge-pea)

480

Conyza canadensis (horseweed) 226

Corylus americana

(American hazelnut)

44,116

Corylus cornuta

(beaked hazelnut)

20

Dactylis glomerata

(orchardgrass)

51

\section{Danthonia spicata \\ (poverty-oatgrass)

$$
634,716
$$

Desmodium (tick-trefoil)

$$
480
$$

Elymus canadensis

(Canada wildrye)
19,603

\section{Elytrigia repens (quack-grass) 549}

\section{Eryngium yuccifolium}

(rattlesnake master)

29,319

Euphorbia esula (leafy spurge) 312

Euphorbia corollata

(flowering spurge) $319,325,469$

Fagus grandifolia

(American beech)

$$
387
$$

Festuca arundinacea

(see Festuca elatior)

Festuca elatior (tall fescue) 574

Festuca ovina (sheep fescue) 817

Festuca rubra (red fescue) 47

Fraxinus americana (white ash) 659

Fraxinus pennsylvanica (green ash) 659

Geranium bicknellii (crane's-bill) 9

Juniperus communis (common juniper) 202

\section{Juniperus virginiana \\ (eastern red cedar) 289}

Larix laricina (tamarack) 387

Lespedeza (bush-clovers) 480
Liatris spicata

(spike blazing-star)

504, 505

Lonicera japonica

(Japanese honeysuckle) 56,641

Lonicera tatarica

(Tartarian honeysuckle) 40

Lupinus perennis (wild lupine) 282

Melilotus alba

(white sweetclover) 317

Monarda fistulosa

(wild bergamot) 182,183

Opuntia (prickly pear cactus) 338,739

Ostrya virginiana (ironwood) 147

Oxalis violacea

(violet wood-sorrel) 76

Panicum (panic-grass) 326

Panicum leibergii (prairie panic-grass) 325

Panicum oligosanthes (few-flowered panic-grass) 325, 392

Panicum virgatum (switchgrass) $10,11,392,405,754$

Pastinaca sativa (wild parsnip) 29

Penstemon grandiflorus (large-flowered beard-tongue) 184,185 
Phalaris arundinacea

(reed canary-grass) 308

Phragmites australis (giant reed) 729

\section{Picea mariana (black spruce)} 682,683

\section{Pinus banksiana (jack pine)} 7, 16, 129, 137, 149, 194, 495, 613, $660,661,682,683,687,697,728$, 784

\section{Pinus resinosa (red pine)} 20, 74, 146, 149, 199, 227, 614, 747,787

Pinus strobus (white pine) $343,387,536,685$

\section{Pinus sylvestris (scotch pine)} 387

Poa (bluegrass) 326
Poa pratensis

(Kentucky bluegrass)

10, 11, 29, 84, 109, 174, 208, 217, $225,325,326,338,391,484,499$, $521,549,597,734,838$

Populus (poplar, aspen) $278,473,657$

Populus grandidentata

(big-toothed aspen)

$$
147,659
$$

Populus tremuloides

(trembling aspen) $47,51,59,62,111,112,113,147$, $189,386,659,709,785,786,788$

Prunus serotina (blackcherry) $321,322,589$

Pteridium aquilinum

(bracken fern) 758

\section{Quercus (oaks)}

$8,32,126,272,461,465,466$, $612,623,793,810,835$
Quercus alba (white oak) $89,209,281,322,531$

Quercus ellipsoidalis

(northern pin-oak or Hill's oak) $355,589,800$

Quercus macrocarpa (bur oak) $102,206,355$

Quercus muehlenbergii

(yellow oak or chinquapin oak) 102

Quercus rubra (red oak) $147,170,374,377,430,531,659$, 836

Quercus velutina (black oak) $46,318,321,322,659$

Ratibida pinnata

(yellow coneflower) $29,182,183$

Rhamnus cathartica (common buckthorn) 40

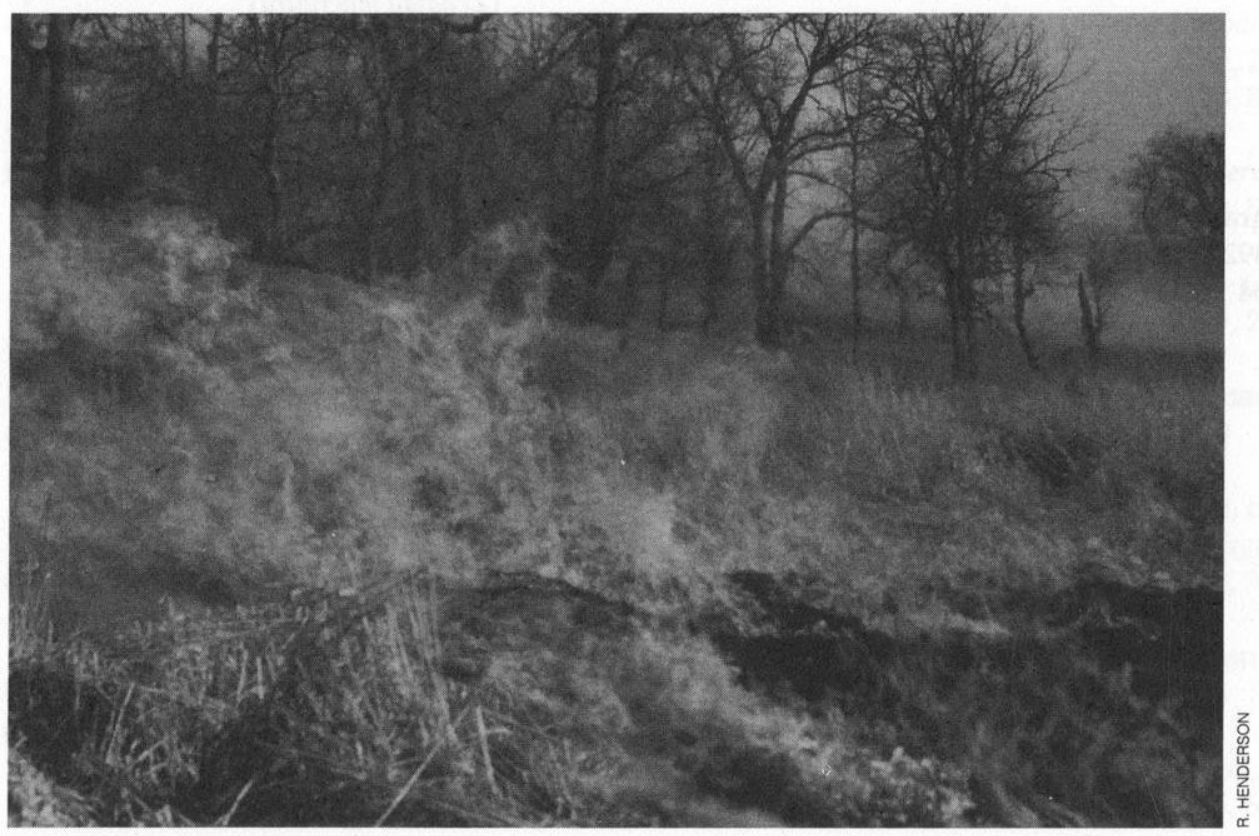

A fast-moving, high-intensity head-fire through reed canary-grass. 
Rhamnus frangula

(European alder-buckthorn) 572

Rhus glabra (smooth sumac) 232

\section{Rhus radicans}

(see Toxicodendron radicans)

Rubus allegheniensis

(common blackberry)

589

Rubus idaeus (red raspberry) 51

Rubus strigosus

(see Rubus idaeus)

Salix (willow)

473

Schizachyrium scoparium

(little bluestem)

$10,11,13,19,29,80,99,100,195$,

$196,197,208,211,217,223,226$,

$325,326,392,407,435,524,528$,

$603,668,716,734,831,838$

Sisyrinchium campestre

(blue-eyed grass)

$319,325,469$

Solidago (goldenrods)

29,716

Sorghastrum nutans (Indiangrass)

$10,19,29,208,326,391,392,407$,

$435,483,484,542,603,734$

Spartina pectinata

(prairie cordgrass)

311

Sporobolus heterolepis

(prairie dropseed)

$19,217,325,597$

Stipa (needlegrasses)

$100,349,506,830$

Stipa spartea (needlegrass) 49,325
Symphoricarpos occidentalis

(wolfberry)

51,609

Thuja occidentalis (white cedar) 455,751

Tilia americana (basswood) 147

Toxicodendron radicans (poison ivy) 232

Tsuga canadensis (eastern hemlock) 244, 246

Typha (cattail)

$55,523,726$

Viola pedatifida (prairie violet) $319,325,469$

\section{INVERTEBRATES}

Ant, harvestor

(Pogonomyrmex badius) 494

Beetles, June (Phyllophaga) 643

Earthworm (Diplocardia smithii) 364

Earthworm (Diplocardia verrucosa) 364

Mosquitoes (Aedes) 776

Moth, pine budworm

(Choristoneura pinus) 495

Skipper, Dakota (Hesperia dacotae) 179,491

Skipper, Ottoe (Hesperia ottoe) 179

Tick, deer

(Ixodes scapularis, I. dammini) 485

\section{REPTILES AND \\ AMPHIBIANS}

Bullsnake

(Pituophis melanoleucus) 228

Garter snake, eastern

(Thamnophis sirtalis) 228

Garter snake, eastern plains

(Thamnophis radix) 228

Racerunner, six-lined

(Cnemidophorus sexlineatus) 515

Skink, five-lined

(Eumeces fasciatus) 517

\section{BIRDS}

Bobwhite, northern

(Colinus virginianus)

$80,138,216,220,228,359,412$, $452,522,652,677,804$

\section{Dove, mourning \\ (Zenaida macroura) 216}

Goose, Canada

(Branta canadensis) 270

Grouse, ruffed (Bonasa umbellus) $188,207,279,606,608,655$

Grouse, sharptail

(Tympanuchus phasianellus) $188,279,527$

Jay, blue (Cyanocitta cristata) 376

Mallard (Anas platyrhynchos) 228

Meadowlark, western

(Sturnella neglecta) 228 
Pheasant, ring-necked

(Phasianus colchicus) 228

Prairie chicken

(Tympanuchus cupido) 130, 279, 292, 409, 795, 796

Sandpiper, upland

(Bartramia longicauda) 350, 398

Sparrow, Baird's

(Ammodramus bairdii) 575

Sparrow, clay-colored

(Spizella pallida) 575

Sparrow, field (Spizella pusilla) 78,350

Sparrow, grasshopper

(Ammodramus savannarum) $350,673,805$

Sparrow, Henslow's

(Ammodramus henslowii)

840

Sparrow, lark

(Chondestes grammacus)

594

Sparrow, savannah

(Passerculus sandwichensis) 575

Teal, blue-winged (Anas discors) 379

Turkey, wild

(Meleagris gallopavo)

$123,545,607$

Warbler, Kirtland's

(Dendroica kirtlandii) 527

Woodcock, American

(Scolopax minor)

216
Woodpecker, black-backed

(Picoides arcticus) 527

\section{SMALL MAMMALS}

Chipmunk, least

(Tamias minimus)

118

\section{Deermouse}

(Peromyscus maniculatus) $64,118,162,211,383,385,569$, 678,679

Ground squirrel, thirteen-lined

(Spermophlilus tridecemlineatus) 64,142

Mice (Peromyscus) 382

Mouse, harvest

(Reithrodontomys megalotis) $141,162,228,385,569,678,679$

Mouse, lemming

(Synaptomys cooperi) 141

Mouse, white-footed

(Peromyscus leucopus) 211

\section{Shrews (Blarina) 382}

Shrews (Sorex) 382

Shrew, Indiana (Sorex cinereus) 118

Shrew, pigmy (Sorex hoyi) 285

Shrew, saddle-backed

(Sorex arcticus) 285

Shrew, short-tailed

(Blarina brevicauda) 678,680
Voles (Microtus) 382

Vole, meadow

(Microtus pennsylvanicus) $678,679,743$

Vole, prairie

(Microtus ochrogaster) 141,228

Vole, red-backed

(Clethrionomys gapperi) 64,118

LARGE MAMMALS

Bear, black (Ursus americanus) 482

Beaver (Castor canadensis) 573

Bison (Bison bison) $166,656,690,754,755$

Caribou, woodland

(Rangifer tarandus) 249, 632

Deer, white-tailed (Odocoileus virginiana) 201, 206, 358, 726, 731, 751, 770, 828,829

Elk (Cervus elaphus) $378,558,662,745$

Moose (Alces alces) $249,259,276,288,473,527,788$

Pine marten (Martes americana) 410

Rabbit, cottontail (Sylvilagus floridanus) $228,396,458,741,804$

Raccoon (Procyon lotor) 708

Squirrel, fox (Sciurus niger) 395,684 


\section{GEOGRAPHIC INDEX}

\section{(U. S. States and Canadian Provinces)}

Alabama
96,677
Alaska
$\quad 259,288,473$
Alberta
$\quad 23,50,167,207$
Arizona
$\quad 87,88,222,348,618,707,727,771$,
$\quad 802$
British Columbia
252,558
California
$\quad 83,162,234,366,368,389,390$,
$\quad 394,401,497,513$
Colorado
$54,303,669$
Connecticut
528,779
Florida

2, 3, 92, 103, 104, 105, 221, 265, 330, $426,502,515,516,517,522,584$, $585,637,699,765,811,841$

\section{Georgia} $117,177,178,451,478,532,654$

Idaho $113,168,237$

Illinois $28,34,35,36,40,78,197,220,245$, $377,391,492,530,535,546,596$, $639,640,641,642,795$

\section{Indiana}

$40,46,155,211,318,572$

Iowa

$19,217,218,219,339,411,557$, $597,604,652,791$

\section{Kansas}

$4,5,6,10,11,21,25,26,27,43,77$, 97, 101, 102, 106, 124, 140, 141, $142,208,229,238,263,264,265$, $267,274,284,328,347,351,354$, $372,383,384,385,403,404,405$, $406,407,441,443,444,499,542$, $544,569,644,667,734,754,755$, 840

Labrador 243

\author{
Louisiana \\ 563,726 \\ Maine \\ 360
}

\section{Manitoba} $344,345,632,780,817$

Maryland 738

\section{Massachusetts} $213,214,215$

\section{Michigan}

$7,9,246,464,547,634,635,660$, $661,751,807$

\section{Minnesota}

$15,20,38,39,44,52,53,71,79$, $118,143,144,145,146,147,148$, $179,182,183,184,248,283,313$, $355,375,495,496,525,526,549$, $562,623,675,709,710,713,715$, $723,724,744,800,801,818$

\section{Missouri}

$289,329,411,432,433,434,435$ $436,463,676,749$

\section{Montana} $86,276,333,378,482,745$

Nebraska $69,99,228,483,484,678,679$

\section{Nevada}

506

\section{New Hampshire} 327

New Jersey $89,119,120,172,455,487,488$, 489,819

New York

$448,485,531,573,687,716$

\section{North Dakota}

290, 333, 334, 398, 399, 409, 537, 839

\section{Northwest Territories} 369

\section{Ohio}

$$
37,121,133,282
$$

\section{Oklahoma}

$13,14,80,90,223,224,233,372$, $373,392,458,595,656,703,731$
Ontario

$55,249,343,666,697,784,785$, 786,787

Oregon $198,254,255,357,500,583$

Pennsylvania 12

Quebec $72,73,74,194,202,554,555,682$, 683

Rhode Island 110

Saskatchewan $41,137,191,575,587,609$

South Carolina $81,774,776$

\section{South Dakota} $84,206,225,285,333,350,379$, $580,689,799$

\section{Tennessee} $193,201,300,301,804$

Texas $123,130,161,235,298,361,694$, $739,820,831$

Utah 297,672

Vermont 227

Virginia 810

Washington 169

West Virginia $545,607,608,793$

Wisconsin $29,40,108,125,173,204,209,210$, $277,279,287,292,293,319,321$, $322,323,324,325,326,430,440$, $450,459,467,469,470,471,560$, $561,589,590,598,603,605,659$, $685,714,759,760,761,762,763$, $764,770,808,813,821,822,823$, $824,826,836,838$

Wyoming $62,113,189,240,662,794$ 


\section{Literature CitATIONS}

1. Abouguendia, Z. M. and W. C. Whitman 1979. Disappearance of dead plant material in a mixed-grass prairie. Oecologia 42:23-30.

2. Abrahamson, W. G.

1984. Species responses to fire on the Florida Lake Wales Ridge. American Journal of Botany 71:35-43.

3. Abrahamson, W. G.

1991. South Florida (USA) slash pine mortality in seasonal ponds. Florida Scientist 54(2):80-83.

4. Abrams, M. D.

1985. Fire history of oak gallery forests in a northeast Kansas tallgrass prairie. American Midland Naturalist 114(1):188-91.

5. Abrams, M. D.

1988. Effects of burning regime on buried seed banks and canopy coverage in a Kansas tallgrass prairie. Southwestern Naturalist 33(1):65-70.

6. Abrams, M. D.

1988. Effects of prescribed fire on woody vegetation in a gallery forest understory in northeastern Kansas. Transactions of the Kansas Academy of Science 91(3-4):63-70.

7. Abrams, M. D.

1989. Post-fire revegetation of jack pine sites in Michigan: an example of successional complexities. Proceedings Tall Timbers Fire Ecology Conference 17:197-209.

8. Abrams, M. D.

1992. Fire and the development of oak forests: in eastern North America, oak distribution reflects a variety of ecological paths and disturbance conditions. Bioscience 42(5):346-53.

9. Abrams, M. D. and D. I. Dickman.

1984. Apparent heat stimulation of buried seeds of Geranium bicknelli on jack pine sites in northern lower Michigan. Michigan Botanist 23:81-88.

10. Abrams, M. D. and L. C. Hulbert.

1987. Effect of topographic position and fire on species composition in tallgrass prairie in northeast Kansas. American Midland Naturalist 117(2):442-45.

11. Abrams, M. D., A. K. Knapp, and L. C. Hulbert.

1986. A ten-year record of above ground biomass in a Kansas tallgrass prairie: effects of fire and topographic position. American Journal of Botany 73(10):1509-15.
12. Abrams, M. D. and G. J. Nowacki.

1992. Historical variation in fire, oak recruitment, and post-logging accelerated succession in central Pennsylvania. Bulletin of the Torrey Botanical Club 119(1):19-28.

13. Adams, D. E. and R. C. Anderson.

1978. The response of a central Oklahoma grassland to burning. Southwestern Naturalist 23(4):623-32.

14. Adams, D. E., R. C. Anderson, and S. L. Collins.

1982. Differential response of woody and herbaceous species to summer and winter burning in an Oklahoma grassland. Southwestern Naturalist 27(1):55-61.

15. Ahlgren, C. E.

1963. Some basic ecological factors in prescribed burning in northeastern Minnesota. Proceedings Tall Timbers Fire Ecology Conference 2:143-49.

16. Ahlgren, C. E.

1974. Effects of fires on temperate forests: north central United States. pp. 195-223 in T. T. Kozlowski and C. E. Ahlgren, eds. Fire and ecosystems. Academic Press, New York. 542 pp.

17. Ahlgren, I. F.

1974. The effects of fire on soil organisms. pp. 47-72 in T. T. Kozlowski and C. E. Ahlgren, eds. Fire and ecosystems. Academic Press, New York. 542 pp.

18. Ahlgren, I. F. and C. E. Ahlgren.

1960. Ecological effects of forest fires. Botanical Review 26:483-533.

19. Aikman, J. M.

1955. Burning in the management of prairie in Iowa. Proceedings of the Iowa Academy of Science 62:53-62.

20. Alban, D. H.

1977. Influence on soil properties of prescribed burning under mature red pine. U.S. Department of Agriculture Forest Service Research Paper NC-139. 8 pp.

21. Aldous, A. E.

1934. Effect of burning on Kansas bluestem pastures. Kansas Agricultural Experiment Station Technical Bulletin 38. 65 pp.

22. Almendros, G., F. J. Gonzalezvila, and F. Martin

1990. Fire-induced transformation of soil organic matter from an oak forest: an experimental approach to the effects of fire on humic substance. Soil Science 149(3):158-68. 
23. Anderson, H. G. and A. W. Bailey.

1980. Effects of annual burning on grassland in the aspen parkland of east-central Alberta. Canadian Journal of Botany 58:985-96.

24. Anderson, J. M.

1991. The effects of climate change on decomposition processes in grassland and coniferous forests. Ecological Applications 1(3):326-47.

25. Anderson, $\mathrm{K}$.

1964. Burning Flint Hill bluestem range. Proceedings Tall Timbers Fire Ecology Conference 3:89-103.

26. Anderson, K. L.

1965. Time of burning as it affects soil moisture in an ordinary upland prairie in the Flint Hills. Journal of Range Management 18:311-16.

27. Anderson, K. L., E. F. Smith, and C. E. Owensby.

1970. Burning bluestem range. Journal of Range Management 23:81-92.

28. Anderson, R. C.

1972. Prairie history, management and restoration in southern Illinois. pp. 15-22 in J. H. Zimmerman, ed. Proceedings of the 2 nd Midwest Prairie Conference. J. H. Zimmerman, Madison, Wis. $242 \mathrm{pp}$.

29. Anderson, R. C.

1973. The use of fire as a management tool on the Curtis Prairie. Proceedings Tall Timbers Fire Ecology Conference 12:23-35.

30. Anderson, R. C.

1982. An evolutionary model summarizing the roles of fire, climate and grazing animals in the origin and maintenance of grasslands: an end paper. pp. 297-308 in J. J. Estes, R. J. Tyrl, and J. N. Bunken, eds. Grasses and grasslands: systematics and ecology. University of Oklahoma Press, Norman. 312 pp.

31. Anderson, R. C.

1990. The historic role of fire in the North American grassland. pp. 8-18 in S. L. Collins and L. L. Wallace, eds. Fire in North American tallgrass prairies. University of Oklahoma Press, Norman. $175 \mathrm{pp}$.

32. Anderson, R. C. and L. E. Brown.

1983. Comparative effects of fire on trees in a midwestern savannah and adjacent forest. Bulletin of the Torrey Botanical Club 110:87-90.

33. Anderson, R. C. and L. E. Brown.

1986. Stability and instability in plant communities following fire. American Journal of Botany 73:364-68.
34. Anderson, R. C., T. Leahy, and S. S. Dhillion.

1989. Numbers and biomass of selected insect groups on burned and unburned sand prairie. American Midland Naturalist 122(1):151-62.

35. Anderson, R. C. and J. Schwegman.

1971. The response of southern Illinois barren vegetation to prescribed burning. Illinois Academy of Science Transactions 64:287-91.

36. Anderson, R. C. and J. Schwegman.

1989. Twenty years of vegetational change on a southern Illinois barren. Bulletin of the Ecological Society of America 70(2):51.

37. Annala, A. E. and L. A. Kapustka.

1982. The microbial response to fire in the Lynx Prairie, Adams County, Ohio. Prairie Naturalist 14(4):101-12.

38. Apfelbaum, S. I. and A. W. Haney.

1981. Bird populations before and after wildfire in a Great Lakes pine forest. Condor 83:347-54.

39. Apfelbaum, S. I. and A. W. Haney.

1986. Changes in bird populations during succession following fire in the northern Great Lakes wilderness. pp. 10-16 in U.S. Department of Agriculture Forest Service General Technical Report INT-212. 553 pp.

40. Apfelbaum, S. I. and A. W. Haney.

1989. Management of degraded oak savanna remnants in the upper midwest: Preliminary results from three years of study. pp. 280-91 in H. G. Hughes and T. M. Bonnicksen, eds. Proceedings of 1st Annual Conference of the Society for Ecological Restoration. Oakland, California, 16-20 January 1989.

41. Archibold, O. W

1979. Buried viable propagules as a factor in postfire regeneration in northern Saskatchewan. Canadian Journal of Botany 57:54-58.

42. Arnett, W. H.

1960. Responses of acridid populations to rangeland practices and range sites. Kansas State University, Manhattan. Ph.D. Dissertation. 117 pp.

43. Asrar, G., T. T. Harris, and R. L. Lapitan.

1988. Radiative surface temperatures of the burned and unburned areas in a tallgrass prairie. Remote Sensing of Environment 24(3):447-57.

44. Axelrod, A. N. and F. D. Irving.

1978. Some effects of prescribed fire at Cedar Creek Natural History Area. Journal of the Minnesota Academy of Science 44(2):9-11. 
45. Backman, A. E.

1988. Fire and disease history of forests. pp. 603-32 in B. Huntley and T. Webb, eds. Vegetation history. Kluwer Academic, Norwell, Mass. 816 pp.

46. Bacone, J. A. and T. W. Post.

1986. Effects of prescribed burning on woody and herbaceous vegetation in black oak sand savannas at Hoosier Prairie Nature Preserve, Lake County, Indiana. pp. 86-90 in A. L. Koonce, ed. Proceedings of Prescribed Burning in the Midwest: State of the Art. University of Wisconsin-Stevens Point. 162 pp.

47. Bailey, A. W.

1987. Woodland to grassland: fire and grazing versus mechanical clearing in the Canadian aspen parkland. pp. 592-93 in P. J. Joss, P. W. Lynch, and O. B. Williams, eds. Rangelands: a resource under siege. Cambridge University Press, New York. 634 pp.

48. Bailey, A. W.

1988. Understanding fire ecology for range management. pp. 527-57 in P. T. Tueller, ed. Vegetation Science Applications for Rangelands Analysis and Management. $642 \mathrm{pp}$.

49. Bailey, A. W. and M. L. Anderson.

1978. Prescribed burning of a Festuca-Stipa grassland. Journal of Range Management 31:446-49.

50. Bailey, A. W. and M. L. Anderson.

1980. Fire temperatures in grass, shrub, and aspen forest communities in central Alberta. Journal of Range Management 33:37-40.

51. Bailey, A. W., B. D. Irving, and R. D. Fitzgerald.

1990. Regeneration of woody species following burning and grazing in aspen parkland. Journal of Range Management 43(3):212-15.

52. Baker, W. L.

1989. Effects of scale and spatial heterogeneity on fire-interval distributions. Canadian Journal of Forest Research 19(6):700-06.

53. Baker, W. L.

1992. Effects of settlement and fire suppression on landscape structure. Ecology 73(5):1879-87.

54. Baker, W. L. and T. Veblem.

1990. Spruce beetles and fires in the 19 th century subalpine forests of western Colorado, USA. Arctic and Alpine Research 22(1):65-80.

55. Ball, J. P.

1990. Influence of subsequent flooding depth on cattail control by burning and flooding. Journal of Aquatic Plant Management 28:32-36.
56. Barden, L. S. and J. F. Mathews.

1980. Changes in abundance of honeysuckle Lonicera japonica and other ground flora after prescribed burning of a piedmont pine forest. Castanea 45:257-60.

57. Barden, L. S. and F. W. Woods.

1974. Characteristics of lighting fires in southern Appalachian forests. Proceedings Tall Timbers Fire Ecology Conference 13:345-61.

58. Barker, N. G. and G. B. Williamson.

1988. Effects of a winter fire on Sarracenia altata and S. psittacina. American Journal of Botany 75(1):138-43.

59. Barnes, B. V.

1966. The clonal growth habit of American aspen. Ecology 47(3):439-47.

60. Barrett, S. W., S. F. Arno, and C. H. Key.

1991. Fire regimes of western larch lodgepole pine forests in Glacier National Park, Montana. Canadian Journal of Forest Research 21(12):1711-20.

61. Bartoli, A., R. Gerdol, and G. Massari.

1991. Soil fungi succession in a Mediterranean Macchia after fire. Revue D'Écologie et de Biologie du Sol 28(4):387-402.

62. Bartos, D. L., W. F. Mueggler, and R. B. Campbell

1991. Regeneration of aspen by suckering on burned sites in western Wyoming. U.S. Department of Agriculture Forest Service Research Paper INT-448. $10 \mathrm{pp}$.

63. Baumgartener, D. C. and A. J. Simard.

1982. Wildlife fire management economics: a state of the art review and bibliography. U.S. Department of Agriculture Forest Service General Technical Report NC-72. 46 pp.

64. Beck, A. M. and R. J. Vogl.

1972. The effects of spring burning on rodent populations in a brush prairie savanna. Journal of Mammalogy 53:336-46.

65. Bell, R. L. and D. Binkley.

1989. Soil nitrogen mineralization and immobilization in response to periodic prescribed fire in a loblolly pine plantation. Canadian Journal of Forest Research 19(6):816-20.

66. Belsky, J. A.

1992. Effects of grazing, competition, disturbance and fire on species composition and diversity in grassland communities. Journal of Vegetation Science 3(2):187-200. 
67. Bendell, J. F.

1974. Effects of fire on birds and mammals. pp. 73-138 in T. T. Kozlowski and C. E. Ahlgren, eds. Fire and ecosystems. Academic Press, New York. 542 pp.

68. Bennet, A. J. R.

1992. Determination of fire-residence time, and its role in the survival of eucalyptus after a bushfire. Australian Journal of Botany 40:49-57.

69. Benning, T. L. and T. B. Bragg.

1993. Response of big bluestem (Andropogon gerardii Vitman) to timing of spring burning. American Midland Naturalist 130(1):127-32.

70. Bentivenga, S. P. and B. D. Hetrick.

1991. Relationship between mycorrhizal activity, burning, and plant productivity in tallgrass prairie Canadian Journal of Botany 69(12):2597-602.

71. Berg, W. E.

1979. Wildland habitat development study. Minnesota Wildlife Research Quarterly 39(3):97-118.

72. Bergeron, $\mathrm{Y}$.

1991. The influence of island and mainland lakeshore landscapes on boreal forest fire regimes. Ecology 72(6):1980-92.

73. Bergeron, Y. and S. Archambault.

1989. Relation between fire cycle and recent climatic change in the southern boreal forest. Bulletin of the Ecological Society of America 70(2):61.

74. Bergeron, $\mathrm{Y}$. and J. Brisson.

1990. Fire regime in red pine stands at the northern limit of the species range. Ecology 71(4):1352-64.

75. Bernardo, D. J., D. M. Engle, and E. T. McCollum.

1988. An economic assessment of risk and returns from prescribed burning on tallgrass prairie. Journal of Range Management 41(2):178-83.

76. Bernhardt, $P$.

1990. Pollination ecology of Oxalis violacea (Oxalidaceae) following a controlled grass fire. Plant Systematics and Ecology 171:1-4.

77. Bertwell, R. L. and H. D. Blocker.

1975. Curculionidae from different grassland treatments near Manhattan, Kansas. Journal of the Kansas Entomological Society 48:319-26.

78. Best, L. B.

1979. Effects of fire on a field sparrow population. American Midland Naturalist 101(2):434-42.

79. Beyerhelm, C. D. and F. D. Irving.

1980. Frequency of suitable prescribed burning weather in east-central Minnesota. University of Minnesota Agricultural Experiment Station Technical Bulletin 327. 6 pp.
80. Bidwell, T. G., D. M. Engle, and P. L. Claypool.

1990. Effects of spring headfires on tallgrass prairie. Journal of Range Management 43(3):209-11.

81. Binkley, D., D. Richter, M. B. David, and B. Caldwell. 1992. Soil chemistry in loblolly/longleaf pine forest with interval burning. Ecological Applications 2(2):157-64.

82. Biondini, M. E., A. A. Steuter, and C. E. Grygiel.

1989. Seasonal fire effects on the diversity patterns, spatial distribution, and community structure of forbs in the northern mixed prairie, USA. Vegetatio 85:21-32.

83. Biswell, H. H.

1967. Forest fire in perspective. Proceedings Tall Timbers Fire Ecology Conference 7:43-63.

84. Blankespoor, G. W.

1987. The effects of prescribed burning on a tall-grass prairie remnant in eastern South Dakota. Prairie Naturalist 19(3):177-88

85. Boardman, W.S.

1967. Wildfire and natural area preservation. Proceedings Tall Timbers Fire Ecology Conference 6:135-42.

86. Bock, C. E. and J. H. Bock.

1987. Avian habitat occupancy following fire in a Montana shrubsteppe. Prairie Naturalist 19:153-58.

87. Bock, C. E. and J. H. Bock

1988. Grassland birds in southeastern Arizona: impacts of fire, grazing, and alien vegetation pp. 43-58 in P. D. Goriup, ed. Ecology and conservation of grassland birds. Technical Publication 7. International Council for Bird Preservation, Cambridge. $250 \mathrm{pp}$.

88. Bock, C. E. and J. H. Bock.

1991. Response of grasshoppers (Orthoptera: Acrididae) to wildfire in a southeastern Arizona grassland. American Midland Naturalist 125(1):162-67.

89. Boerner, R. E., T. R. Lord, and J. C. Peterson.

1988. Prescribed burning in the oak-pine forest of the New Jersey pine barrens: effects on the growth and nutrient dynamics of two Quercus species. American Midland Naturalist 120(1):108-19.

90. Boggs, J. F., R. L. Lochmiller, S. T. McMurry, D. M. Leslie, and D. M. Engle.

1991. Cuterebra infestations in small-mammal communities as influenced by herbicides and fire. Journal of Mammalogy 72(2):322-27.

91. Bonninghausen, R. A.

1962. The Florida Forest Service and controlled burning. Proceedings Tall Timbers Fire Ecology Conference 1:43-52. 
92. Bonninghausen, R. A.

1962. Forest land management and the use of fire. Proceedings Tall Timbers Fire Ecology Conference 1:127-32.

93. Bormann, F. H. and G. E. Likens.

1979. Catastrophic disturbance and the steady state in northern hardwood forest. American Scientist 67(6):660-69.

94. Botha, S. A. and D. C. Lemaitre.

1992. Effects of seed and seedling predation by small mammals on seedling recruitment of Protea neriifolia in Swartboskloof, Cape Province. South African Journal of Zoology 27(2):60-69.

95. Boubel, R. W., E. F. Darley, and E. A. Schuck.

1969. Emissions from burning grass stubble and straw. Journal of the Air Pollution Control Association 19(7):497-500.

96. Boyer, W. D.

1990. Growing-season burns for control of hardwoods in longleaf pine stands. U.S. Department of Agriculture Forest Service Research Paper SO-256. $7 \mathrm{pp}$.

97. Bragg, T. B.

1974. Woody plant succession on various soils of unburned bluestem prairie in Kansas. Kansas State University, Manhattan. Ph.D. Dissertation. 80 pp.

98. Bragg, T. B.

1978. Annual variation in the burning potential of a bluestem prairie. Bulletin of the Ecological Society of America 59:109.

99. Bragg, T. B.

1982. Seasonal variation in fuel and fuel consumption by fires in a bluestem prairie. Ecology 63(1):7-11.

100. Bragg, T. B.

1989. Nutrient composition of burned and unburned C 3 and C4 grass species. Bulletin of the Ecological Society of America 70(2):69.

101. Bragg, T. B. and L. C. Hulbert.

1976. Woody plant invasion of unburned Kansas bluestem prairie. Journal of Range Management 29:19-24.

102. Bragg, W. K., A. K. Knapp, and J. M. Briggs.

1993. Comparative water relations of seedling and adult Quercus species during gallery forest expansion in tallgrass prairie. Forest Ecology and Management 56(1-4):29-41.

103. Breininger, D. R. and P. A. Schmalzer.

1990. Effects of fire and disturbance on plants and birds in a Florida oak palmetto scrub community. American Midland Naturalist 123(1):6474.
104. Breininger, D. R. and R. B. Smith.

1992. Relationships between fire and bird density in coastal scrub and slash pine flatwoods in Florida. American Midland Naturalist 127(2):233-40.

105. Brenner, J. and D. Wade.

1992. Florida's 1990 prescribed burning act: protection for responsible burners. Journal of Forestry 90(5):27-30.

106. Briggs, J. M. and D. J. Gibson.

1992. Effect of fire on tree spatial patterns in a tallgrass prairie landscape. Bulletin of the Torrey Botanical Club 119(3):300-07.

107. Britton, C. M. and H. A. Wright

1983. Brush management with fire. pp. $61-68$ in K. C. $\mathrm{McDaniel}$, ed. Proceedings: Brush Management Symposium. Texas Tech University, Lubbock. 104 pp.

108. Brown, C. T.

1967. Growth and energy relationships on burned and unburned prairie in southern Wisconsin. University of Wisconsin-Madison, M. S. Thesis. $51 \mathrm{pp}$.

109. Brown, E. M.

1943. Seasonal variation in the growth and chemical composition of Kentucky bluegrass. Missouri Agricultural Experiment Station Bulletin 360 $56 \mathrm{pp}$.

110. Brown, J. H.

1960. The role of fire in altering the species composition of forests in Rhode Island. Ecology 41:310-16.

111. Brown, J. K. and N. V. DeByle.

1978. Fire damage, mortality, and suckering in aspen. Canadian Journal of Forest Research 17(9):1100-09.

112. Brown, J. K. and N. V. DeByle.

1989. Effects of prescribed burning on biomass and plant succession in western aspen. U.S. Forest Service Research Paper INT-412. 16 pp.

113. Brown, J. K. and D. G. Simmerman

1986. Appraising fuels and flammability in western aspen: a prescribed fire guide. U.S. Department of Agriculture Forest Service General Technical Report INT-205. 48 pp.

114. Brown, P. J., P. T. Manders, D. P. Bands,

F. J. Kruger, and R. H. Andrag.

1991. Prescribed burning as a conservation management practice: a case history from the Cederberg Mountains, Cape Province, South-Africa. Biological Conservation 56(2):133-50. 
115. Broza, M., D. Poliakov, S. Weber, and I. Izhaki.

1993. Soil microarthropods on post-fire pine forest on Mount Carmel, Israel. Water Science and Technology 27(7-8):533-38.

116. Buckman, R. E.

1964. Effects of prescribed burning on hazel in Minnesota. Ecology 45:626-29.

117. Buckner, J. L. and J. L. Landers.

1979. Fire and disking effects on herbaceous food plants and seed supplies. Journal of Wildlife Management 43:807-11.

118. Buech, R. R., K. Siderits, R. E. Radtke,

H. L. Sheldon, and D. Elsing.

1977. Small mammal populations after a wildfire in northeast Minnesota. U.S. Department of Agriculture Forest Service Research Paper NC151. $8 \mathrm{pp}$.

119. Buell, M. F., H. F. Buell, and J. A. Small.

1954. Fire in the history of Mettler's Woods. Bulletin of the Torrey Botanical Club 81:252-55.

120. Buffington, J. D.

1967. Soil arthropod populations of the New Jersey pine barrens as affected by fire. Annals Entomological Society of America 60:530-35.

121. Bulan, C. A. and G. W. Barrett.

1971. The effects of two acute stresses on the arthropod component of an experimental grassland ecosystem. Ecology 52(4):597-605.

122. Buttrick, P. L.

1912. The effect of forest fires on trees and reproduction in southern New England. Forestry Quarterly 10:13.

123. Campo, J. J., W. G. Swank, and C. R. Hopkins.

1989. Brood habitat use by eastern wild turkeys in eastern Texas. Journal of Wildlife Management 53(2):479-82.

124. Cancelado, R. and T. R. Yonke.

1970. Effect of prairie burning on insect populations. Journal of the Kansas Entomological Society 43:274-81.

125. Canham, C. D. and O. L. Loucks.

1984. Catastrophic windthrow of the presettlement forests of Wisconsin. Ecology 65(3):803-09.

126. Canham, C. D. and P. L. Marks

1985. The response of woody plants to disturbance: patterns of establishment and growth. pp. 197216 in S. T. A. Pickett and P. S. White, eds. The ecology of natural disturbance and patch dynamics. Academic Press, New York. 472 pp.
127. Carpenter, F. L. and H. F. Rechter.

1979. Pollination, reproduction, and fire. American Midland Naturalist 113:871-79.

128. Cartalis, C. and G. Eftihidis.

1992. The impact of a forest fire on the air pollution of an urban area: a case-study for Athens, Greece. Toxicological and Environmental Chemistry 35(1-2):9-16.

129. Cayford, J. H.

1970. The role of fire in the ecology and silviculture of jack pine. Proceedings Tall Timbers Fire Ecology Conference 10:221-44.

130. Chamrad, A. D. and J. D. Dodd.

1972. Prescribed burning and grazing for prairie chicken habitat manipulation in Texas coastal prairie. Proceedings Tall Timbers Fire Ecology Conference 12:257-76.

131. Chandler, C., P. Cheney, P. Thomas,

L. Trabaud, and D. Williams.

1983. Fire in forestry. Volume I: forest fire behavior and effects. John Wiley and Sons, New York. 450 pp.

132. Chandra, $P$.

1962. Note on the effect of shifting temperatures on nitrification in a loam soil. Canadian Journal of Soil Science 42:314-15.

133. Chapman, F. B.

1949. Wildlife losses from forest fires in Ohio. Paper presented at 11th Midwest Fish and Wildlife Conference. Madison, Wisconsin, December 1949. 3 pp.

134. Cheplick, G. P. and J. A. Quinn.

1987. The role of seed depth, litter, and fire in the seedling establishment of amphicarpic peanutgrass (Amphicarpum purshii). Oecologia 73(3):459-64.

135. Cheplick, G. P. and J. A. Quinn.

1988. Subterranean seed production and population responses to fire in Amphicarpum purshii (Gramineae). Journal of Ecology 76(1):263-73.

136. Christiansen, E. C. and S. G. Pickford.

1991. Natural abatement of fire hazard in Douglas fir blowdown and thinning fuelbeds. Northwest Science 65(4):141-48.

137. Chrosciewicz, Z.

1988. Jack pine regeneration following postcut burning under seed trees in central Saskatchewan. Forestry Chronicle 64(4):315-19. 
138. Church, K. E. and R. Wells.

1988. Effects of prescribed burning and seasonal grazing on bobwhite abundance. 50th Midwest Fish and Wildlife Conference. Columbus, Ohio, 4-7 December 1988. 116 pp.

139. Claridge, A. W.

1992. Is the relationship among mycophagous marsupials, mycorrhizal fungi and plants dependent on fire? Australian Journal of Ecology 17(2):223-25.

140. Clark, B. K.

1990. Influence of plant litter and habitat structure on small mammal assemblages: experimental manipulations and field observations. Kansas State University, Ph. D. Dissertation. 138 pp.

141. Clark, B. K. and D. W. Kaufman.

1990. Short-term responses of small mammals to experimental fire in tallgrass prairie. Canadian Journal of Zoology 68(11):2450-54.

142. Clark, B. K., D. W. Kaufman, G. A. Kaufman,

S. K. Gurtz, and S. Hand Bixler.

1992. Population ecology of thirteen-lined ground squirrels in ungrazed tallgrass prairie manipulated by fire. pp. 51-54 in D. D. Smith and C. A. Jacobs, eds. Proceedings of the 12th North American Prairie Conference. University of Northern Iowa, Cedar Falls. 218 pp.

143. Clark, J. S

1988. Effect of climate change on fire regimes in northwestern Minnesota. Nature 334(6179):233-34.

144. Clark, J. S.

1988. Climate change, fire occurrence, and forest influences during the last 750 years in northwestern Minnesota. University of Minnesota, Ph. D. Dissertation. 183 pp.

145. Clark, J. S.

1989. Ecological disturbance as a renewal process: theory and application to fire history. Oikos 56(1):17-30.

146. Clark, J. S.

1990. Fire and climate change during the last 750 years in northwestern Minnesota. Ecological Monographs 60(2):135-59.

147. Clark, J. S.

1990. Landscape interactions among nitrogen mineralization, species composition, and long term fire frequency. Biogeochemistry 11(1):1-22.

148. Clark, J. S.

1990. Twentieth century climate change, fire suppression, and forest production and decomposition in northwestern Minnesota (USA). Canadian Journal of Forest Research 20(2):219-32.
149. Clark, J. S.

1991. Disturbance and tree life history on the shifting mosaic landscape. Ecology 72(3):1102-18.

150. Clark, J. S., J. Merkt, and H. Mueller.

1989. Post glacial fire, vegetation, and human history on the northern alpine forelands, south western Germany (West Germany). Journal of Ecology 77(4):897-925.

151. Cofer, W. R., J. S. Levine, E. L. Winstead, and B. J. Stocks.

1990. Gaseous emission from Canadian boreal forest fires. Atmospheric Environment 24(7):1653-59.

152. Cofer, W. R., J. S. Levine, E. L. Winstead, and B. J. Stocks.

1991. New estimates of nitrous oxide emissions from biomass burning. Nature 349(6311):689-91.

153. Cohen, W. B. and P. N. Omi.

1991. Water-stress effects on heating-related water transport in woody plants. Canadian Journal of Forest Research 21(2):199-206.

154. Cohen, W. B., P. N. Omi, and M. R. Kaufmann.

1990. Heating related water transport to intact lodgepole pine branches. Forest Science 36(2):246-54

155. Cole, K. L., K. F. Klick, and N. B. Pavlovic.

1992. Fire temperature monitoring during experimental burns at Indiana Dunes National Lake Shore. Natural Areas Journal 12(4):177-83.

156. Collins, S. L.

1990. Introduction: fire as a natural disturbance in tallgrass prairie ecosystems. pp. 3-7 in S. L. Collins and L. L. Wallace, eds. Fire in North American tallgrass prairies. University of Oklahoma Press, Norman. 175 pp.

157. Collins, S. L. and S. C. Barber.

1985. Effects of disturbance in mixed-grass prairie. Vegetatio 64:87-94

158. Collins, S. L. and D. J. Gibson.

1990. Effects of fire on community structure in tallgrass and mixed-grass prairie. pp. 81-98 in S. L. Collins and L. L. Wallace, eds. Fire in North American tallgrass prairies. University of Oklahoma Press, Norman. 175 pp.

159. Collins, S. L. and L. L. Wallace, eds.

1990. Fire in North American tallgrass prairies. University of Oklahoma Press, Norman. 175 pp. 
160. Coloff, S., J. Byrne, M. Mott-Smith, and M. Rogers. 1985. Smoke management and regulatory requirements. Chapter I, pp. 1-5 in Prescribed Fire and Fire Effects Working Team. Prescribed fire: smoke management guide. U.S. Department of Agriculture, National Wildfire Coordinating Group, Washington, D.C. 28 pp.

161. Conner, R. N., D. C. Randolph, D. L. Kulhavy, and A. E. Snow.

1991. Causes of mortality of red cockaded woodpecker cavity trees. Journal of Wildlife Management 55(3):531-37.

162. Cook, S. F., Jr.

1959. The effects of fire on a population of small rodents. Ecology 40:102-08.

163. Cooper, R. W.

1962. Is prescribed burning paying off? Proceedings Tall Timbers Fire Ecology Conference 1:145-50.

164. Cooper, R. W.

1963. Knowing when to burn. Proceedings Tall Timbers Fire Ecology Conference 2:31-34.

165. Cooper, R. W.

1974. Status of prescribed burning. Proceedings Tall Timbers Fire Ecology Conference 13:309-15.

166. Coppock, D. L. and J. K. Detling.

1986. Alternation of bison and black-tailed prairie dog grazing interaction by prescribed burning. Journal of Wildlife Management 50(3):452-55.

167. Courtney, R. F.

1989. Pronghorn use of recently burned mixed prairie in Alberta. Journal of Wildlife Management 53(2):302-05.

168. Crane, M. F. and W. C. Fischer.

1986. Fire ecology of the forest habitat types of central Idaho. U.S. Department of Agriculture Forest Service General Technical Report INT-218. 86 pp.

169. Crawford, C. S. and R. F. Harwood.

1964. Bionomics and control of insects affecting Washington grass seed fields. Washington State Agricultural Experiment Station Technical Bulletin 44. 25 pp.

170. Crowe, T. R.

1988. Reproductive mode and mechanisms for selfreplacement of northern red oak (Quercus rubra): a review. Forest Science 34(1):19-40.

171. Crowner, A. W. and G. W. Barrett.

1979. Effect of fire on the small mammal component of an experimental grassland community. Journal of Mammalogy 60:803-13.
172. Cumming, J. A.

1969. Prescribed burning on recreation areas in New Jersey: history, objectives, influence and technique. Proceedings Tall Timbers Fire Ecology Conference 9:251-69.

173. Curtis, J. T

1959. The vegetation of Wisconsin: an ordination of plant communities. University of Wisconsin Press, Madison. 657 pp.

174. Curtis, J. T. and M. L. Partch.

1948. Effect of fire on the competition between bluegrass and certain prairie plants. American Midland Naturalist 39:437-43.

175. Curtis, J. T. and M. L. Partch.

1950. Some factors effecting flower production in Andropogon gerardi. Ecology 31:488-9.

176. Cushwa, C. T., R. E. Martin, and R. L. Miller.

1968. The effects of fire on seed germination. Journal of Range Management 21(4):250-54.

177. Cypert, E.

1961. The effects of fires in the Okefenokee Swamp. American Midland Naturalist 66:485-503.

178. Czuhai, E. and C. T. Cushwa.

1968. A resume of prescribed burnings on the Piedmont National Wildlife Refuge. U.S. Forest Service Research Note SE-86. 4 pp.

179. Dana, R. P.

1991. Conservation management of the prairie skippers Hesperia dacotae and Hesperia ottoe: basic biology and threat of mortality during prescribed burning in spring. Agricultural Experiment Station Bulletin 594. University of Minnesota.

180. Darley, E. F., F. R. Burleson, E. H. Mateer,

J. T. Middleton, and V. P. Osterli.

1966. Contribution of burning of agricultural wastes to photochemical air pollution. Journal of the Air Pollution and Control Association 11(12):685-90.

181. Daubenmire, $R$.

1968. Ecology of fire in grasslands. Advances in Ecological Research 5:209-66.

182. Davis, M. A., K. M. Lemon, and A. M. Dybvig.

1987. The effects of burning and insect herbivory on seed production of two prairie forbs. Prairie Naturalist 19:93-100.

183. Davis, M. A., K. M. Lemon, and A. M. Dybvig.

1988. The impact of fire on the interactions of two prairie plants and their seed predators. [var. pp.] in A. Davis and G. Stanford, eds. Proceedings of the 10th North American Prairie Conference. Native Prairie Association of Texas, Dallas. $334 \mathrm{pp}$. 
184. Davis, M. A., J. Villinski, K. Banks,

J. Buckman-Fifield, J. Dicus, and S. Hofmann.

1991. Combined effects of fire, mound-building by pocket gophers, root loss and plant size on growth and reproduction in Penstemon grandiflorus. American Midland Naturalist 125(1):150-61.

185. Davis, M. A., J. Villinski, S. McAndrew,

H. Scholtz, and E. Young.

1991. Survivorship of Penstemon grandiflorus in an oak woodland - combined effects of fire and pocket gophers. Oecologia 86(1):113-18.

186. Day, G. M.

1953. The Indian as an ecological factor in the northeastern forest. Ecology 34(2):329-46.

187. De Ronde, C.

1990. Impact of prescribed fire on soil properties: comparison with wildfire effects. pp. 127-36 in J. G. Goldammer and M. J. Jenkins, eds. Fire in ecosystem dynamics: Mediterranean and northern perspectives. SPB Academic Publishing bv, The Hague, Netherlands. 199 pp.

188. DeByle, N. V.

1985. Managing wildlife habitat with fire in the aspen ecosystem. pp. 73-82 in U.S. Department of Agriculture Forest Service General Technical Report INT-186. 89 pp.

189. DeByle, N. V., P. J. Urness, and D. L. Blank.

1989. Forage quality in burned and unburned aspen communities. U.S. Department of Agriculture Forest Service Research Paper INT-404. 8 pp.

190. Deeming, J. E.

1978. Fire behavior: how to predict it. Paper presented at Prairie Prescribed Burning Symposium and Workshop. Jamestown, N.D., 26 April 1978. $18 \mathrm{pp}$.

191. DeJong, E. and K. B. McDonald.

1975. The soil moisture regime under native grassland. Geoderma 14:207-21

192. Denevan, W. M.

1992. The pristine myth: the landscape of the Americas in 1492. Annals of the Association of American Geographers 82(3):369-85.

193. DeSelm, H. R., E. C. Clebsch, G. M. Nichols, and E. Thor.

1974. Response of herbs, shrubs, and tree sprouts in prescribed burn hardwoods in Tennessee. Proceedings Tall Timbers Fire Ecology Conference 13:331-44.
194. Desponts, M. and S. Payette.

1992. Recent dynamics of jack pine at its northern distribution limit in northern Quebec. Canadian Journal of Botany 70(6):1157-67.

195. Dhillion, S. S., R. C. Anderson, and A. E. Liberta.

1988. Effect of fire on the mycorrhizal ecology of little bluestem Schizachyrium scoparium. Canadian Journal of Botany 66(4):706-13.

196. Dhillion, S. S. and R. C. Anderson.

1989. Variation in little bluestem tissue, inorganic nutrients, and biomass production on burned and unburned sand prairie. Bulletin of the Ecological Society of America 70(2):97.

197. Dhillion, S. S. and R. C. Anderson.

1993. Growth dynamics and associated mycorrhizal fungi of little bluestem grass [Schizachyrium scoparium (Michx) Nash] on burned and unburned sand prairies. New Phytologist 123(1):77-91.

198. Dickman, A. and S. Cook.

1989. Fire and fungus in a mountain hemlock forest. Canadian Journal of Botany 67(7):2005-16.

199. Dickmann, D. I., W. J. O'Neill, and N. Caverey.

1987. Wide-spaced red pine: a multiple use opportunity. Northern Journal of Applied Forestry 4:44-5.

200. Dickson, J. G.

1991. Birds and mammals of pre-colonial southern old-growth forests. Natural Areas Journal 11(1):26-33.

201. Dills, G. G.

1970. Effects of prescribed burning on deer browse. Journal of Wildlife Management 34:540-45.

202. Diotte, M. and Y. Bergeron.

1989. Fire and the distribution of Juniperus communis L. in the boreal forest of Quebec, Canada. Journal of Biogeography 16(1):91-96.

203. Dix, R. L.

1960. The effects of burning on the mulch structure and species composition of grasslands in western North Dakota. Ecology 41:49-56.

204. Dix, R. L. and J. E. Butler.

1954. The effect of fire on a dry thin-soil prairie in Wisconsin. Journal of Range Management 7:265-86. 
205. Dobrowolski, J. P., W. H. Blackburn, and H. E. Grelen.

1987. Effects of 20 years of prescribed burning on infiltration rates, sediment production, and water quality of southern rangeland soils. pp. 581-82 in P. J. Joss, P. W. Lynch and O. B. Williams, eds. Rangelands: a resource under siege. Cambridge Press, New York. 634 pp.

206. Dodgen, J. and D. Bradford.

1989. An evaluation of prescribed burning to stimulate bur oak production for white-tailed deer browse. Society of Range Management Annual Meeting 42:236.

207. Doerr, P. D., L. B. Keith, and D. H. Rusch.

1970. Effects of fire on a ruffed grouse population. Proceedings Tall Timbers Fire Ecology Conference 10:25-46.

208. Dokken, D. and L. C. Hulbert.

1978. Effect of standing dead plants on stem density in bluestem prairie. pp. $78-81$ in D. C. GlenLevin and R. Q. Landers, eds. Proceedings of the 5th Midwest Prairie Conference. Iowa State University, Ames. 230 pp.

209. Dorney, C. H. and J. R. Dorney.

1989. An unusual oak savanna in northeastern Wisconsin: the effects of Indian-caused fire. American Midland Naturalist 122(1):103-13.

210. Dorney, J. R.

1981. The impact of Native Americans on presettlement vegetation in south-eastern Wisconsin. Transactions of the Wisconsin Academy of Science, Arts, and Letters 69:26-36.

211. Dubis, D., R. A. Strait, M. T. Jackson,

and J. O. Witaker, Jr.

1988. Floristics and effects of burning vegetation and on small mammal populations at Little Bluestem Prairie Nature Preserve. Natural Areas Journal 8(4):267-76.

212. Duley, F. L.

1939. Surface factors affecting the rate of intake of water by soils. Proceedings of the Soil Science Society of America 4:60-64.

213. Dunwiddie, P. W.

1991. Forest history and composition of Halfway Pond Island, Plymouth County, Massachusetts. Rhodora 93(876):347-60.

214. Dunwiddie, P. W.

1991. Comparisons of aboveground Arthropods in burned, mowed and untreated sites in sandplain grasslands on Nantucket Island. American Midland Naturalist 125(2):206-12.
215. Dunwiddie, P. W. and C. Caljouw.

1990. Prescribed burning and mowing of coastal heathlands and grasslands in Massachusetts. pp. 271-75 in R. S. Mitchell, C. J. Sheviak and D. J. Leopold, eds. Ecosystem management: rare species and significant habitats. New York State Museum Bulletin 471. 314 pp.

216. Edwards, R. E. and J. A. Ellis.

1969. Response of three avian species to burning Wilson Bulletin 81(3):338-89.

217. Ehrenreich, J. G.

1959. Effect of burning and clipping on growth of native prairie in Iowa. Journal of Range Management 12:133-37.

218. Ehrenreich, J. H. and J. M. Aikman.

1957. Effect of burning on seed stalk production of native prairie grasses. Proceedings of the Iowa Academy of Science 64:205-12.

219. Ehrenreich, J. H. and J. M. Aikman.

1963. An ecological study of the effect of certain management practices on native prairie in Iowa. Ecological Monographs 33:113-30.

220. Ellis, J. A., W. R. Edwards, and K. P. Thomas.

1969. Response of bobwhites to management in Illinois. Journal of Wildlife Management 33:749-62.

221. Emlen, J. T.

1970. Habitat selection by birds following a forest fire. Ecology 51:343-45.

222. Emmerich, W. E. and J. R. Cox.

1992. Hydrologic characteristics immediately after seasonal burning on introduced and native grasslands. Journal of Range Management 45(5):476-79.

223. Engle, D. M., T. G. Bidwell, A. L. Ewing, and J. R. Williams.

1989. A technique for quantifying fire behavior in grassland fire ecology studies. Southwestern Naturalist 34(1):79-84.

224. Engle, D. M., T. G. Bidwell, J. F. Stritzke, and D. Rollins.

1990. Atrazine and burning in tallgrass prairie infested with prairie threeawn. Journal of Range Management 43(5):424-27.

225. Engle, D. M. and P. M. Bultsma.

1984. Burning of northern mixed prairies during drought. Journal of Range Management 37(5):398-401. 
226. Engle, D. M., J. F. Stritzke, and F. T. McCollum.

1991. Vegetation management in the cross timbers: response of understory vegetation to herbicides and burning. Weed Technology 5(2):406-10.

227. Engstrom, F. B. and D. H. Mann.

1991. Fire ecology of red pine (Pinus resinosa) in northern Vermont, USA. Canadian Journal of Forest Research 21(6):882-9.

228. Erwin, W. J. and R. H. Stasiak.

1979. Vertebrate mortality during the burning of a reestablished prairie in Nebraska. American Midland Naturalist 101:247-49.

229. Evans, E. W.

1988. Community dynamics of prairie grasshoppers subjected to periodic fire-predictable trajectories or random walks in time. Oikos 52(3):283-92.

230. Evans, E. W.

1988. Grasshopper (Insecta: Orthoptera: Acrididae) assemblages of tallgrass prairie: influences of fire frequency, topography, and vegetation. Canadian Journal of Zoology 66(7):1495-501.

231. Evans, E. W., R. A. Rogers, and D. J. Opfermann. 1983. Sampling grasshoppers (Orthoptera: Acrididae) on burned and unburned tallgrass prairie: night trapping vs. sweeping. Bulletin of the Entomological Society of America 12(5):1449-54.

232. Evans, J. E.

1983. A literature review of management practices for smooth sumac (Rhus glabra), poison ivy (Rhus radicans) and other sumac species. Natural Areas Journal 3(1):10-26.

233. Ewing, A. L. and D. M. Engle.

1988. Effects of late summer fire on tallgrass prairie microclimate and community composition. American Midland Naturalist 120(1):212-23.

234. Fenn, M. E. and P. H. Dunn.

1989. Litter decomposition across an air pollution gradient in the San Bernardino Mountains (California, USA). Soil Science Society of America Journal 53(5):1560-7.

235. Ferguson, E. R.

1957. Stem-kill and sprouting following prescribed fires in a pine-hardwood stand in Texas. Journal of Forestry 55:426-9.

236. Ffolliott, P. F., D. P. Guertin, and W. D. Rasmussen. 1988. Simulating the impacts of fire: a computer program. Environmental Management 12(6):809-14.
237. Fielding, D. J. and M. A. Brusven.

1993. Spatial Analysis of Grasshopper Density and Ecological Disturbance on Southern Idaho Rangeland. Agriculture Ecosystems \& Environment 43(1):31-47.

238. Finck, E. J.

1986. Management of grassland birds and small mammals. Paper presented at 48 th Midwest Fish and Wildlife Conference. Omaha, Nebraska, 7-10 December 1986. 203 pp

239. Fischer, W. C. and J. K. Brown.

1991. A document database system for managing fire effects knowledge. The Compiler 9(1):29-34.

240. Fisher, R. F., M. J. Jenkins, and W. F. Fisher.

1987. Fire and the prairie-forest mosaic of Devil's Tower National Monument. American Midland Naturalist 117(2):250-57.

241. Flieger, B. W.

1970. Forest fire and insects: the relation of fire to insect outbreak. Proceedings Tall Timbers Fire Ecology Conference 10:107-14.

242. Fonteyn, P. J., M. W. Stone, M. A. Yancy, and J. T. Baccus.

1984. Interspecific and intraspecific microhabitat temperature variations during a fire. American Midland Naturalist 112(2):246-50.

243. Foster, D. R. and G. A. King

1986. Vegetation pattern and diversity in S.E. Labrador, Canada: Betula papyrifera forest development in relation to fire history and physiography. Journal of Ecology 74(2):465-84.

244. Foster, D. R. and T. M. Zebryk.

1993. Long-term vegetation dynamics and disturbance history of a Tsuga-dominated forest in New England. Ecology 74(4):982-98.

245. Fralish, J. S., F. B. Crooks, J. L. Chambers, and F. M. Harty.

1991. Comparison of presettlement, 2nd-growth and old-growth forest on 6 site types in the Illinois Shawnee Hills. American Midland Naturalist 125(2):294-309.

246. Frelich, L. E. and C. G. Lorimer

1991. Natural disturbance regimes in hemlock hardwood forests of the Upper Great Lakes region. Ecological Monographs 61(2):145-64.

247. French, D. W. and F. Irving

1973. Dwarf mistletoe eradication by burning. pp. 116-8 in A. L. Koonce, ed. Prescribed burning in the Midwest: state of the art. University of Wisconsin-Stevens Point. $162 \mathrm{pp}$. 
248. Frissell, S. S.

1973. The importance of fire as a natural ecological factor in Itasca State Park, Minnesota. Quaternary Research 3:397-407.

249. Fritz, R., R. Suffling, and T. A. Younger.

1993. Influence of fur trade, famine, and forest fires on moose and woodland caribou populations in northwestern Ontario from 1786 to 1911. Environmental Management 17(4):477-89.

250. Frohn, R. C

1989. The effects of wildfire and prescribed burning on the structure and foraging composition of avian communities. Ohio Journal of Science 89(2):44.

251. Fryer, G. I. and E. A. Johnson.

1988. Reconstructing fire behavior and effects in a subalpine forest. Journal of Applied Ecology 25(3):1063-72.

252. Fyles, J. W., I. H. Fyles, W. J. Beese, and M. C. Feller. 1991. Forest floor characteristics and soil nitrogen availability on slash-burned sites in coastal British Columbia (Canada). Canadian Journal of Forest Research 21(10):1516-22.

253. Gajewski, K., M. G. Winkler, and A. M. Swain.

1985. Vegetation and fire history from three lakes with varved sediments in northwestern Wisconsin. Review of Paleobotany and Palynology 44:277-92.

254. Gara, R. I.

1988. Interactions between fires, fungi, mountain pine beetles, and lodgepole pine in south-central Oregon. Northwestern Environmental Journal 4(2):355.

255. Gara, R. I., J. K. Agee, W. R. Littke, and D. R. Geizler. 1986. Fire wounds and beetle scars. Journal of Forestry 84(4):47-50.

256. Gartner, F. R. and W. W. Thompson.

1973. Fire in the Black Hills forest-grass ecotone. Proceedings Tall Timbers Fire Ecology Conference 12:37-68.

257. Gartner, F. R. and E. M. White.

1987. Fire in the northern great plains and its use in management. Paper presented at Prescribed Fire and Smoke Management Symposium. Society of Range Management 39th Annual Meeting. Kissimmee, Florida, 13 February 1986. $21 \mathrm{pp}$.

258. Garty, J.

1992. The postfire recovery of rock-inhabiting algae, microfungi, and lichens. Canadian Journal of Botany 70(2):301-12.
259. Gasaway, W. C., S. D. DuBois, R. D. Boertje,

D. J. Reed, and D. T. Simpson.

1989. Response of radio-collared moose to a large burn in central Alaska. Canadian Journal of Zoology 67(2):325-29.

260. Gaylor, H. P.

1974. Wildfires: prevention and control. Robert J. Brady Company, Bowie, Maryland. 319 pp.

261. Gerstle, R. W. and D. A. Kemnitz.

1967. Atmospheric emissions from open burning. Journal of the Air Pollution Control Association 17(5):324-27.

262. Gibson, D. J.

1988. Regeneration and fluctuation of tallgrass prairie vegetation in response to burning frequency. Bulletin of the Torrey Botanical Club 115(1):1-12.

263. Gibson, D. J.

1989. Effects of animal disturbance on tallgrass prairie vegetation. American Midland Naturalist 121:144-54.

264. Gibson, D. J., C. C. Freeman, and L. C. Hulbert.

1990. Effects of small mammal and invertebrate herbivory on plant species richness and abundance in tallgrass prairie. Oecologia 84(2):169-75.

265. Gibson, D. J., D. C. Hartnett, and G. L. S. Merrill. 1990. Fire temperature heterogeneity in contrasting fire prone habitats: Kansas tallgrass prairie and Florida sandhill. Bulletin of the Torrey Botanical Club 117(4):349-56.

266. Gibson, D. J. and L. C. Hulbert.

1987. Effects of fire, topography and year-to-year climatic variation of species composition in tallgrass prairie. Vegetatio 72:175-85.

267. Gibson, D. J., T. R. Seastedt, and J. M. Briggs.

1993. Management practices in tallgrass prairie: large-scale and small-scale experimental effects on species composition. Journal of Applied Ecology 30(2):247-55.

268. Gilliam, F. S.

1988. Interactions of fire with nutrients in the herbaceous layer of a nutrient-poor coastal plain forest. Bulletin of the Torrey Botanical Club 115(4):265-71

269. Gillon, D. and M. Rapp.

1989. Nutrient losses during a winter low intensity prescribed fire in a Mediterranean forest. Plant and Soil 120(1):69-78. 
270. Givens, L. S.

1962. Use of fire on southeastern wildlife refuges. Proceedings Tall Timbers Fire Ecology Conference 1:121-26.

271. Gleason, H. A.

1912. An isolated prairie grove and its phytogeographical significance. Botanical Gazette 53:38-49.

272. Gleason, H. A.

1913. The relation of forest distribution and prairie fires in the middle west. Torreya 13:173-81.

273. Glendening, G. E.

1942. Germination and emergence of some native grasses in relation to litter cover and soil moisture. Journal of the American Society of Agronomy 34:797-804.

274. Glenn, S. M. and S. L. Collins.

1992. Effects of scale and disturbance on rates of immigration and extinction of species in prairies. Oikos 63(2):273-80.

275. Glenn-Lewin, D. C., L. A. Johnson, T. W. Jurik,

A. Akey, M. Leoschke, and T. Rosburg

1990. Fire in central North American grasslands: Vegetative reproduction, seed germination, and seedling establishment. pp. 28-45 in S. L. Collins and L. L. Wallace, eds. Fire in North American tallgrass prairies. University of Oklahoma Press, Norman. 175 pp.

276. Gordon, F. A.

1974. Spring burning in an aspen-conifer stand for maintenance of moose habitat, West Boulder River, Montana. Proceedings Tall Timbers Fire Ecology Conference 14:501-38.

277. Gorte, R. W. and D. C. Baumbartner.

1983. A fire effects appraisal system for Wisconsin. U.S. Department of Agriculture Forest Service General Technical Report NC-90. 8 pp.

278. Graham, S. A., R. P. Harrison, and C. E. Westell.

1963. Aspen: phoenix trees of the great lakes region. University of Michigan Press, Ann Arbor. 272 pp.

279. Grange, W. B.

1948. The relation of fire to grouse. pp. 193-205 in Wisconsin Grouse Problems. Wisconsin Conservation Department Publication No. 328. 318 pp.

280. Granstrom, A. and J. Schimmel.

1993. Heat effects on seeds and rhizomes of a selection of boreal forest plants and potential reaction to fire. Oecologia 94(3):307-13.

281. Greenley, W. B. and W. W. Ashe.

1907. White oak in the southern Appalachians. U.S. Department of Agriculture Forest Service Circular 105. 27 pp.
282. Grigore, $\mathrm{M}$.

1992. The short-term effect of fire on wild lupine (Lupinus perennis L.). University of Toledo, Ohio. M.S. Thesis. 73 pp.

283. Grimm, E. C.

1984. Fire and other factors controlling the Big Woods vegetation of Minnesota in the mid-nineteenth century. Ecological Monographs 54:291-311.

284. Groffman, P. M., C. W. Rice, and J. M. Tiedie.

1993. Dentrification in a tallgrass prairie landscape. Ecology 74(3):855-62.

285. Gruebele, M. J. and A. A. Steuter.

1988. South Dakota records of pygmy and arctic shrews: response to fire. Prairie Naturalist 20(2):95-98.

286. Gruell, G. E., J. K. Brown, and C. L. Bushey.

1986. Prescribed fire opportunities in grasslands invaded by douglas-fir: state-of-the-art guidelines. U.S. Department of Agriculture Forest Service General Technical Report INT-198. 19 pp.

287. Guernsey, O. and J. F. Willard.

1856. History of Rock County. Doty and Brother, Printers, Janesville, Wisconsin. 350 pp.

288. Gusaway, W. C., S. D. DuBois, R. D. Boertje, D. J. Reed, and D. T. Simpson.

1989. Response of radio-collared moose to a large burn in central Alaska. Canadian Journal of Zoology 67(2):325-29.

289. Guyette, R. P. and B. E. Cutter.

1991. Tree ring analysis of fire history of a post oak savanna in the Missouri (USA) Ozarks. Natural Areas Journal 11(2):93-99.

290. Hadley, E. B.

1970. Net productivity and burning response of native eastern North Dakota prairie communities. American Midland Naturalist 84:121-35.

291. Hadley, E. B. and B. J. Kieckhefer.

1963. Productivity of two prairie grasses in relation to fire frequency. Ecology 44:389-95.

292. Halvorsen, H. H.

1981. An evaluation of grassland management practices for wildlife in central Wisconsin. University of Wisconsin-Stevens Point. M. S. Thesis. $69 \mathrm{pp}$.

293. Halvorsen, H. H. and R. K. Anderson.

1980. Evaluation of grassland management for wildlife in central Wisconsin. pp. 267-79 in C. L. Kucera, ed. Proceedings of the 7 th North American Prairie Conference. Southwest Missouri State University, Springfield. $321 \mathrm{pp}$. 
294. Handley, C. O., Jr.

1969. Fire and mammals. Proceedings Tall Timbers Fire Ecology Conference 9:151-59.

295. Haney, A. and S. I. Apfelbaum.

1990. Structure and dynamics of Midwest oak savannas. pp. 19-30 in J. Sweeny, ed. Management of dynamic ecosystems. North Central Section of the Wildlife Society, West LaFayette, Indiana. 180 pp.

296. Hansen, J. D.

1986. Comparison of insects from burned and unburned areas after a range fire. Great Basin Naturalist 46(4):721-27.

297. Hansen, J. D.

1988. Trapping methods for rangeland insects in burned and unburned sites: a comparison. Great Basin Naturalist 48(3):383-93.

298. Hansmire, J. A., D. L. Drawe, D. B. Webster, and C. M. Britton.

1988. Effect of winter burns on forbs and grasses of the Texas coastal prairie. Southwestern Naturalist 33(3):333-38.

299. Hardison, J. R.

1976. Fire and disease. Proceedings Tall Timbers Fire Ecology Conference 15:223-34.

300. Harmon, $M$.

1982. Fire history of the westernmost portion of Great Smokey Mountains National Park. Bulletin of the Torrey Botanical Club 109:74-79.

301. Harmon, M. E.

1984. Survival of trees after low-intensity surface fire in Great Smokey Mountains National Park. Ecology 65:796-802.

302. Harper, R. M.

1962. Historical notes on the relation of fire to forests. Proceedings Tall Timbers Fire Ecology Conference 1:11-29.

303. Harrington, M. G.

1989. Gambel oak root carbohydrate response to spring, summer, and fall prescribed burning. Journal of Range Management 42(6):504-07.

304. Hartman, H. E.

1976. Forestland fire: industry's enemy and management's ally. Proceedings Tall Timbers Fire Ecology Conference 15:127-33.

305. Hartnett, D. C.

1991. Effects of fire in tallgrass prairie on growth and reproduction of prairie coneflower (Ratibida columnifera, Asteraceae). American Journal of Botany 78(3):429-35.
306. Hartnett, D. C. and D. M. Krofta.

1989. Fifty-five years of post-fire succession in a southern mixed hardwood forest. Bulletin of the Torrey Botanical Club 116(2):107-14.

307. Hartnett, D. C. and D. R. Richardson.

1989. Population biology of Bonamia grandiflora (Convolvulaceae): effects of fire on plant and seed bank dynamics. American Journal of Botany 76(3):361-69.

308. Haslam, S. M.

1973. The management of British wetlands: I. Economic and amenity use. Journal of Environmental Management 1:303-20.

309. Hawley, N. R.

1964. Burning in Naval Stores Forest. Proceedings Tall Timbers Fire Ecology Conference 3:81-87.

310. Hayes, D. C. and T. R. Sestect.

1989. Nitrogen dynamics of soil water in burned and unburned tallgrass prairie. Soil Biology and Biochemistry 21(8):1003-07.

311. Heckathorn, S. A. and E. H. Delucia.

1991. Effect of leaf rolling on gas exchange and leaf temperature of Andropogon gerardii and Spartina pectinata. Botanical Gazette 152(3):263-68.

312. Heidel, B.

1982. Leafy spurge: a challenge in natural areas management. Natural Areas Journal 2(2):10-13.

313. Heinselman, M. L.

1973. Fire in the virgin forests of the Boundary Waters Canoe Area, Minnesota. Quaternary Research 3(3):329-82.

314. Heinselman, M. L.

1978. Fire in wilderness ecosystems. pp. $249-78$ in J. C. Hendee, G. H. Stankey and R. C. Lucas, eds. Wilderness management. U.S. Department of Agriculture Forest Service Miscellaneous Publication No. 1365. 381 pp.

315. Heinselman, M. L.

1981. Fire intensity and frequency as factors in the distribution and structure of northern ecosystems. pp. 7-57 in H. A. Money, T. M. Bonnicksen, N. L. Christensen, J. E. Lotan, and W. A. Reiners, eds. Fire regimes and ecosystem properties. U.S. Department of Agriculture Forest Service General Technical Report WO-26. 593 pp.

316. Heinselman, M. L.

1981. Fire and succession in the conifer forests of northern North America. pp. 374-405 in D. C. West, H. H. Shugart, and D. B. Botkins, eds. Forest succession: concepts and application. Springer-Verlag, New York. 517 pp. 
317. Heitlinger, M. E.

1975. Burning a protected tallgrass prairie to suppress sweetclover, Melilotus alba. pp. 123-32 in M. K. Wali, ed. Prairie: a multiple view. University of North Dakota Press, Grand Forks. 433 pp.

318. Henderson, N. R. and J. N. Long.

1984. A comparison of stand structure and fire history in two black oak woodlands in northwestern Indiana. Botanical Gazette 145:222-8.

319. Henderson, R. A.

1981. The response of forb species to seasonal timing of prescribed burns in remnant Wisconsin prairie. University of Wisconsin-Madison. M.S. Thesis. $145 \mathrm{pp}$.

320. Henderson, R. A.

1982. Vegetation: fire ecology of tallgrass prairie. Natural Areas Journal 2:17-26.

321. Henderson, R. A.

1983. Fire tolerance of black cherry and black oak saplings in a savanna (Wisconsin). Restoration and Management Notes 1(4):17.

322. Henderson, R. A.

1986. Response of seedling and sapling trees to a spring fire in a Wisconsin oak opening. pp. 81-85 in A. L. Koonce, ed. Prescribed burning in the Midwest: state of the art. University of Wisconsin-Stevens Point. 162 pp.

323. Henderson, R. A.

1986. Response of Amelanchier sanguinea to prescribed burns (Wisconsin). Restoration Management Notes 4(1):73.

324. Henderson, R. A.

1992. Effects of spring fire timing on pasque-flower (Anemone patens) flower-bud survival. pp. 117-20 in D. D. Smith and C. A. Jacobs, eds. Proceedings of the 12th North American Prairie Conference. University of Northern Iowa, Cedar Falls. 218 pp.

325. Henderson, R. A.

1992. Ten-year response of a Wisconsin prairie remnant to seasonal timing of fire. pp. 121-26 in D. D. Smith and C. A. Jacobs, eds. Proceedings of the 12th North American Prairie Conference. University of Northern Iowa, Cedar Falls. 218 pp.

326. Henderson, R. A., D. L. Lovell, and E. A. Howell.

1983. The flowering response of 7 grasses to seasonal timing of prescribed burns in remnant Wisconsin prairie. pp. 7-10 in R. Brewer, ed. Proceedings of the 8th North American Prairie Conference. Western Michigan University, Kalamazoo. 175 pp.
327. Henry, J. D. and J. M. A. Swan.

1974. Reconstructing forest history from live and dead plant material: an approach to the study of forest succession in southwest New Hampshire. Ecology 55:772-83.

328. Hensel, R. L.

1923. Effect of burning on vegetation in Kansas pasture. Journal of Agricultural Research 32:631-44.

329. Herman, R. P. and C. L. Kucera.

1975. Vegetation management and microbial function in a tallgrass prairie. Iowa State Journal of Research 50:255-60.

330. Herndon, A., L. Gunderson, and J. Stenberg.

1991. Sawgrass (Cladium jamaicense) survival in a regime of fire and flooding. Wetlands 11(1):17-28.

331. Heyward, F. and W. N. Tissot.

1936. Some changes in the soil fauna associated with forest fires in the long-leaf pine region. Ecology 17:659-66.

332. Higgins, K. F.

1978. Fire Bloopers. Paper presented at Prairie Prescribed Burning Symposium and Workshop. Jamestown, North Dakota, 26 April 1978.

333. Higgins, K. F.

1984. Lightning fires in North Dakota grasslands and in pine savanna lands of South Dakota and Montana. Journal of Range Management 37(2):100-03.

334. Higgins, K. F.

1986. A comparison of burn season effects on nesting birds in North Dakota mixed-grass prairie. Prairie Naturalist 18(4):219-28.

335. Higgins, K. F.

1986. Interpretation and compendium of historical fire accounts in the northern great plains. U.S. Fish and Wildlife Service Research Publication No. 161.39 pp.

336. Higgins, K. F., D. P. Fellows, J. M. Callows, A. D. Kruse, and J. L. Piehl.

1989. Annotated bibliography of fire literature relative to northern grasslands in south central Canada and north central United States. South Dakota State University Extension Circular EC 762. $20 \mathrm{pp}$.

337. Higgins, K. F., A. D. Kruse, and J. L. Piehl

1987. Effects of fire in the northern great plains. South Dakota State University Extension Circular EC-761. $47 \mathrm{pp}$. 
338. Higgins, K. F., A. D. Kruse, and J. L. Piehl.

1989. Prescribed burning guidelines in the northern Great Plains. South Dakota State University Extension Circular EC-760. 47 pp.

339. Hill, G. R. and W. J. Platt.

1975. Some effects of fire upon a tall grass prairie plant community in northwestern Iowa. pp. 103-13 in M. K. Wali, ed. Prairie: a multiple view. University of North Dakota Press, Grand Forks. 433 pp.

340. Hobbs, N. T., D. S. Schimel, C. E. Owensby, and D. S. Ojima.

1991. Fire and grazing in the tallgrass prairie: contingent effects on nitrogen budgets. Ecology 72(4):1374-82.

341. Hobbs, R. J. and L. F. Huenneke.

1992. Disturbance, diversity, and invasion: implications for conservation. Conservation Biology 6(3):324-37.

342. Hoelzer, A. and A. Hoelzer.

1987. Paleoecological studies on a moor at the Hornisgrinde in the Northern Black Forest (West Germany). Carolinea 45:43-50.

343. Holla, T. A. and P. Knowles.

1988. Age structure analysis of a virgin White Pine, Pinus strobus, population. Canadian-Field Naturalist 102(2):221-26.

344. Holliday, N. J.

1991. The carabid fauna (Coleoptera: Carabidae) during postfire regeneration of boreal forest: properties and dynamics of species assemblages. Canadian Journal of Zoology 70:440-52.

345. Holliday, N. J.

1991. Species responses of carabid beetles (Coleoptera: Carabidae) during post-fire regeneration of boreal forest. Canadian Entomologist 123:1369-89.

346. Hopkins, H. H.

1954. Effects of mulch upon certain factors on grassland environment. Journal of Range Management 7:255-59.

347. Hopkins, H. H., F. W. Albertson, and A. Riegel.

1948. Some effects of burning upon a prairie in westcentral Kansas. Kansas Academy of Science Transactions 51(1):31-141.

348. Horton, S. P. and R. W. Mannan.

1988. Effects of prescribed fire on snags and cavitynesting birds in southeastern Arizona pine forests. Wildlife Society Bulletin 16(1):37-44.
349. Hover, E. J. and T. B. Bragg.

1981. Effect of season of burning and mowing on an eastern Nebraska Stipa-Andropogon prairie. American Midland Naturalist 105(1):13-18.

350. Huber, G. E. and A. A. Steuter.

1984. Vegetation profile and grassland bird response to spring burning. Prairie Naturalist 16:55-61.

351. Hulbert, L. C.

1969. Fire and litter effects in undisturbed bluestem prairie in Kansas. Ecology 50:874-77.

352. Hulbert, L. C

1978. Fire effects on tallgrass or bluestem prairie vegetation. Paper presented at Prairie Prescribed Burning Workshop. Jamestown, North Dakota, 25-28 April 1978. 6 pp.

353. Hulbert, L. C.

1988. Causes of fire effects in tallgrass prairie. Ecology 69(1):46-58

354. Hulbert, L. C. and J. K. Wilson.

1983. Fire interval effects on flowering of grasses in Kansas bluestem prairie. pp. 255-57 in C. L. Kucera, ed. Proceedings of the 7 th North American Prairie Conference. Southwest Missouri University, Springfield. $321 \mathrm{pp}$.

355. Irving, F. R. and S. E. Aksamit.

1983. Tree mortality by fire in oak savanna restoration (Minnesota). Restoration and Management Notes 1(4):18-19.

356. Isagi, Y. and N. Nakagoshi.

1990. A Markov approach for describing post fire succession of vegetation. Ecological Research 5(2):163-72.

357. Ivey, G. L., J. P. Clark, C. L. Foster,

R. L. Jarvis, and D. G. Paullin.

1988. Influence of land use on cinnamon teal nesting at Malheur National Wildlife Refuge, Oregon. Paper presented at Symposium on the Ecology and Management of Breeding Waterfowl. Delta Research Station, Winnipeg, Manitoba, 18-22 August 1987.

358. Ivey, T. L. and M. K. Causey.

1984. Response of white-tailed deer to prescribed fire. Wildlife Society Bulletin 12(2):138-41.

359. Jackson, A. S.

1965. Wildfires in the great plains grasslands. Proceedings Tall Timbers Fire Ecology Conference 4:241-59. 
360. Jacobson, G. L., H. Almquist-Jacobson, and J. C. Winne.

1991. Conservation of rare plant habitat: insights from the recent history of vegetation and fire at Crystal Fen, Northern Maine, USA. Biological Conservation 57(3):287-314.

361. Jacoby, P. W., R. J. Ansley, and B. A. Trevino.

1992. An improved method for measuring temperatures during range fires. Journal of Range Management 45(2):216-20.

362. James, S. W.

1982. Effects of fire and soil type on earthworm populations in a tallgrass prairie. Pedobiologia 24:37-40.

363. James, S. W.

1985. An unexpected effect of autumn burning on tallgrass prairie. American Midland Naturalist 114(2):400-03.

364. James, S. W.

1988. The postfire environment and earthworm population in tallgrass prairie. Ecology 69(2):476-83.

365. Jenkins, B. M., I. M. Kennedy, S. Q. Turn,

R. B. Williams, S. G. Hall, S. V. Teague,

D. P. Y. Chang, and O. G. Raabe.

1993. Wind tunnel modeling of atmospheric emissions from agricultural burning: influence of operating configuration on flame structure and particle emission factor for a spreading-type fire. Environmental Science \& Technology 27(9):1763-75

366. Jenkins, B. M., S. Q. Turn, and R. B. Williams.

1992. Atmospheric emissions from agricultural burning in California: determination of burn fractions, distribution factors, and crop-specific contributions. Agriculture Ecosystems \& Environment 38(4):313-30.

367. Johansen, R., J. Deeming, M. Long and D. Ward.

1985. Smoke production characteristics and effects. Chapter II, pp. 5-10 in Prescribed Fire and Fire Effects Working Team. Prescribed fire: smoke management guide. U.S. Department of Agriculture, National Wildfire Coordinating Group, Washington, D.C. $28 \mathrm{pp}$.

368. Johnson, C. M. and P. R. Needham.

1966. Ionic composition of Sagehen Creek, California, following an adjacent fire. Ecology 47:636-39.

369. Johnson, E. A.

1975. Buried seed populations in the sub-arctic forest east of Great Slave Lake, Northwest Territories. Canadian Journal of Botany 53:2933-41.
370. Johnson, E. A.

1992. Fire and vegetation dynamics: studies from the North American boreal forest. Cambridge Studies in Ecology Cambridge, U.K. 142 pp.

371. Johnson, E. A. and C. S. Larsen.

1991. Climatically induced change in fire frequency in the southern Canadian Rockies. Ecology 72(1):194-201.

372. Johnson, F. L.

1986. Oak-hickory savannahs and transition zones: preservation status and management problems. pp. 345-47 in D. L. Kulhavy and R. N. Conner, eds. Wilderness and natural areas in the eastern United States: a management challenge. Austin State University, School of Forestry, Nacogdoches, Texas.

373. Johnson, F. L. and P. G. Risser.

1975. A quantitative comparison between an oak forest and an oak savannah in central Oklahoma. Southwestern Naturalist 20:75-84.

374. Johnson, P. S.

1974. Survival and growth of northern red oak seedlings following a prescribed burn. U.S. Department of Agriculture Forest Service Research Note NC-177. 3 pp.

375. Johnson, R. G. and S. A. Temple.

1986. Assessing habitat quality for birds nesting in fragmented tallgrass prairie. in J. Verner, M. Morrison, and C. Ralph, eds. Wildlife 2000. University of Wisconsin Press, Madison. 470 pp.

376. Johnson, W. C., M. Dixon, C. S. Adkisson, and T. R. Crow.

1992. Differential use of habitats for acorn by blue jays. Abstract 50 in One Hundred and Tenth Stated Meeting of the American Ornithologists' Union (Abstracts). Ames, Iowa, 24-28 June 1992. Iowa State University, Big Bluestem Audubon Society.

377. Jokela, J. J. and R. A. Sawtelle.

1985. Origin of oak stands on the Springfield Plain: a lesson on oak regeneration. pp. 181-88 in J. O. Dawson and K. A. Majerus, eds. Proceedings of the 5th Central Hardwood Forest Conference. University of Illinois, Champaign-Urbana. 299 pp.

378. Jourdonnais, C. S. and D. J. Bedunah.

1990. Prescribed fire and cattle grazing on an elk winter range in Montana. Wildlife Society Bulletin 18(3):232-40.

379. Kaiser, P. H., S. A. Berlinger and R. H. Fredrickson.

1979. Response of blue-winged teal to range management on waterfowl protection areas in southeastern South Dakota. Journal of Range Management 32:295-98 
380. Kantrud, H. A.

1986. Effects of vegetation manipulation on breeding waterfowl in prairie wetlands: a literature review. U.S. Fish and Wildlife Service Technical Report 3.

381. Kauffman, J. B. and R. E. Martin.

1989. Fire behavior, fuel consumption and forest floor changes following prescribed understory fires in Sierra Nevada (California, USA) mixed conifer forests. Canadian Journal of Forest Research 19(4):455-62.

382. Kaufman, D. W., E. J. Finck, and G. A. Kaufman. 1990. Small mammals and grassland fires. pp. 46-80 in S. L. Collins and L. L. Wallace, eds. Fire in North American tallgrass prairies. University of Oklahoma Press, Norman. 175 pp.

383. Kaufman, D. W., S. K. Gurtz, and G. A. Kaufman. 1988. Movement of the deer mouse in response to prairie fire. Prairie Naturalist 20(4):225-29.

384. Kaufman, D. W., G. A. Kaufman, and E. J. Finck. 1983. Effects of fire on rodents in tallgrass prairie of the Flint Hills region of eastern Kansas. Prairie Naturalist 15(2):49-56.

385. Kaufman, G. A., D. W. Kaufman, and E. J. Finck. 1988. Influences of fire and topography on habitat selection by Peromyscus maniculatus and Reithrodontomys megalotis in ungrazed tallgrass. Journal of Mammalogy 69(2):342-52.

386. Kay, C. E.

1993. Aspen seedlings in recently burned areas of Grand Teton and Yellowstone National Parks. Northwest Science 67(2):94-104.

387. Kayll, A. J.

1968. Heat tolerance of tree seedlings. Proceedings Tall Timbers Fire Ecology Conference 8:89-105.

388. Kayll, A. J.

1974. Use of fire in land management. pp. 483-511 in T. T. Kozlowski and C. E. Ahlgren, eds. Fire and ecosystems. Academic Press, New York. $542 \mathrm{pp}$.

389. Keeley, J. E.

1987. Role of fire in seed germination of woody taxa in California chaparral. Ecology 68(2):434-44.

390. Keeley, J. E. and S. C. Keeley.

1987. Role of fire in the germination of chaparral herbs and suffutescents. Madrono 34(3):240-49.

391. Keller, G. T.

1978. Restoring native prairie vegetation. Soil Conservation 43:20.
392. Kelting, R. W.

1957. Winter burning in central Oklahoma grassland. Ecology 38(3):520-22.

393. Kerr, K.

1982. Timing prairie maintenance. Landscape Architecture 72(1):95-96.

394. Kie, J. G.

1984. Deer habitat use after prescribed burning in northern California. U.S. Department of Agriculture Forest Service Research Note PSW-369. 3 pp.

395. Kiltie, R. A.

1989. Wildfire and the evolution of dorsal melanism in fox squirrels, Sciurus niger. Journal of Mammalogy 70(4):726-39.

396. King, S. L., H. L. Stribling, and D. Speake.

1991. Cottontail rabbit initial responses to prescribed burning and cover enhancement. Journal of the Alabama Academy of Science 62(2-3):178-88.

397. Kirby, R. E., S. J. Lewis, and T. N. Sexton.

1988. Fire in North American wetland ecosystems and fire-wildlife relations: an annotated bibliography. U. S. Fish and Wildlife Service Biology Report 88(1):144.

398. Kirsch, L. M. and K. F. Higgins.

1976. Upland sandpiper nesting and management in North Dakota. Wildlife Society Bulletin 4:16-22.

399. Kirsch, L. M. and A. D. Kruse.

1973. Prairie fires and wildlife. Proceedings Tall Timbers Fire Ecology Conference 12:289-303.

400. Kline, V. M. and G. Cottam.

1979. Vegetation response to climate and fire in the driftless area of Wisconsin. Ecology 60:861-68.

401. Klinger, R. C., M. J. Kutilek, and H. S. Shellhammer. 1989. Population responses of black-tailed deer to prescribed burning. Journal of Wildlife Management 53(4):863-71.

402. Klopatek, C. C., L. F. Debano, and J. M. Klopatek. 1988. Effects of simulated fire on vesicular arbuscular mycorrhizae in pinyon-juniper woodland soil. Plant and Soil 109(2):245-50.

403. Knapp, A. K.

1984. Post-burn differences in solar radiation, leaf temperature and water stress influencing production in a lowland tallgrass prairie. American Journal of Botany 71(2):220-27. 
404. Knapp, A. K.

1985. Water relations and growth of three grasses during wet and drought years in a tallgrass prairie. Oecologia 65:35-43.

405. Knapp, A. K.

1985. Effect of fire and drought on the ecophysiology of Andropogon gerardii and Panicum virgatum in a tallgrass prairie. Ecology 66(4):1309-20.

406. Knapp, A. K., J. T. Fahnestock, S. P. Hamburg, L. B. Statland, T. R. Seastedt, and D. S. Schimel.

1993. Landscape patterns in soil plant water relations and primary production in tallgrass prairie. Ecology 74(2):549-60.

407. Knapp, A. K. and L. C. Hulbert.

1986. Production, density and height of flower stalks of three grasses in annually burned and unburned eastern Kansas tallgrass prairie: a four year record. Southwestern Naturalist 31(2):235-41.

408. Knapp, A. K. and T. R. Seastedt.

1986. Detritus accumulation limits productivity of tallgrass prairie. Bioscience 36:662-68.

409. Kobringer, J. D. and D. P. Vollink.

1988. Prairie chicken populations of Sheyenne Delta in North Dakota, 1961-1987. pp. 1-7 in Prairie Chickens: Sheyenne National Grasslands. U.S. Department of Agriculture Forest Service General Technical Report RM-159. 73 pp.

410. Koehler, G. M. and M. G. Hornocker

1977. Fire effects on marten habitat in the SelwayBitterroot Wilderness. Journal of Wildlife Management 41:500-05.

411. Koelling, M. and C. Kucera.

1965. Productivity and turnover relationships in native tallgrass prairie. Iowa State Journal of Science 39:387-92.

412. Koerth, B. H., J. L. Mutz, and J. C. Segers.

1986. Availability of bobwhite foods after burning of pan American balsamscale. Wildlife Society Bulletin 14(2):146-50.

413. Komarek, E. V

1962. Fire ecology. Proceedings Tall Timbers Fire Ecology Conference 1:95-107.

414. Komarek, E. V.

1962. The use of fire: an historical background. Proceedings Tall Timbers Fire Ecology Conference 1:7-10.

415. Komarek, E. V.

1964. The natural history of lightning. Proceedings Tall Timbers Fire Ecology Conference 3:139-83.
416. Komarek, E. V.

1966. The meteorological basis for fire ecology. Proceedings Tall Timbers Fire Ecology Conference 5:85-125.

417. Komarek, E. V

1967. Fire-and the ecology of man. Proceedings Tall Timbers Fire Ecology Conference 6:143-70.

418. Komarek, E. V.

1967. The nature of lightning fires. Proceedings Tall Timbers Fire Ecology Conference 7:5-41.

419. Komarek, E. V

1968. Lightning and lightning fires as ecological forces. Proceedings Tall Timbers Fire Ecology Conference 8:169-97.

420. Komarek, E. V

1970. Controlled burning and air pollution: an ecological review. Proceedings Tall Timbers Fire Ecology Conference 10:141-73.

421. Komarek, E. V.

1973. Ancient fires. Proceedings Tall Timbers Fire Ecology Conference 12:219-40.

422. Komarek, E. V.

1974. Effects of fire on temperate forests and related ecosystems: southeastern United States. pp. 251-77 in T. T. Kozlowski and C. E. Ahlgren, eds. Fire and ecosystems. Academic Press, New York. 542 pp.

423. Komarek, E. V.

1974. Further remarks on controlled burning and air pollution. Proceedings Tall Timbers Fire Ecology Conference 13:279-82.

424. Komarek, E. V.

1974. Introduction to lightning ecology. Proceedings Tall Timbers Fire Ecology Conference 13:421-27.

425. Komarek, E. V., B. B. Komarek, and T. C. Carlysle.

1973. The ecology of smoke particulates and charcoal residues from forest and grassland fires: a preliminary atlas. Tall Timbers Research Station Miscellaneous Publication No. 3. Tall Timbers Research Station, Tallahassee, Fla. 75 pp.

426. Komarek, R

1963. Fire and the changing wildlife habitat. Proceedings Tall Timbers Fire Ecology Conference 2:35-43.

427. Komarek, $\mathrm{R}$.

1966. A discussion of wildlife management, fire and the wildlife landscape. Proceedings Tall Timbers Fire Ecology Conference 5:177-94. 
428. Komarova, T. K.

1985. Role of forest fires in germination of seeds dormant in the soil. Soviet Journal of Ecology 16(6):311-15.

429. Kozlowski, T. T. and C. E. Ahlgren, eds.

1974. Fire and ecosystems. Academic Press, New York, N.Y. 542 pp.

430. Kruger, E. L.

1992. Survival, growth, and ecophysiology of northern red oak (Quercus rubra L.) and competing tree regeneration in response to fire and related disturbance. University of Wisconsin, Madison. Ph.D. Dissertation.

431. Kruse, A. D. and J. L. Piehl.

1986. The impact of prescribed burning on ground nesting birds. pp. 153-56 in G. K. Clambey and R. H. Pemble, eds. Proceeding of the 9th North American Prairie Conference. Tricollege University Center for Environmental Studies, Fargo, North Dakota. 264 pp.

432. Kucera, C. L.

1968. Ecological effects of fire on tallgrass prairie. p. 12 in P. Schramm, ed. Proceedings Symposium on Prairie and Prairie Restoration. Knox College, Galesburg, Illinois. 66 pp.

433. Kucera, C. L. and R. C. Dahlman.

1968. Root-rhizome relationships in fire-treated stands of big bluestem, Andropogon gerardii Vit. American Midland Naturalist 80:268-71.

434. Kucera, C. L., R. Dahlman, and M. Koelling.

1967. Total net productivity and turnover on an energy basis for tallgrass prairie. Ecology 48:536-41.

435. Kucera, C. L. and J. H. Ehrenreich.

1962. Some effects of annual burning on central Missouri prairie. Ecology 43:334-36.

436. Kucera, C. L. and M. Koelling.

1964. The influence of fire on composition of central Missouri prairie. American Midland Naturalist 72:142-47.

437. Lamont, B. B.

1993. Plant senescence in fire-prone perennials. Trends in Ecology \& Evolution 8(4):147.

438. Lamont, B. B., E. T. F. Witkowski, and N. J. Enright. 1993. Post-fire litter microsites: safe for seeds, unsafe for seedlings. Ecology 74(2):501-12.

439. Landers, J. L.

1987. Prescribed burning for managing wildlife in southeastern pine forests. pp. 19-27 in U.S. Department of Agriculture Forest Service General Technical Report SO-65.
440. Lange, K. I.

1990. A postglacial vegetational history of Sauk County and Caledonia Township, Columbia County, South Central Wisconsin (USA). Wisconsin Department of Natural Resources Technical Bulletin 168.40 pp.

441. Launchbaugh, J. L.

1964. Effects of early spring burning on yields of native vegetation. Journal of Range Management 17:5-6.

442. Launchbaugh, J. L.

1973. Effects of fire on shortgrass and mixed prairie species. Proceedings Tall Timbers Fire Ecology Conference 12:129-51.

443. Launchbaugh, J. L.

1978. Fire effects on shortgrass vegetation. Paper presented at Prairie Prescribed Burning Symposium and Workshop. Jamestown, North Dakota, 26 April 1978.

444. Launchbaugh, J. L. and C. E. Launchbaugh.

1978. Kansas rangelands: their management based on a half century of research. Kansas Agricultural Experiment Station Bulletin 622. 56 pp.

445. Lay, D. W.

1956. Effects of prescribed burning on forage and mast production in southern pine forest. Journal of Forestry 54:582-84.

446. Lay, D. W.

1957. Browse quality and the effects of prescribed burning in southern pine forest. Journal of Forestry 55:342-47.

447. Lay, D. W.

1967. Browse palatability and the effects of prescribed burning in southern pine forests. Journal of Forestry 65:826-28.

448. Lay, D. W.

1992. Demography and age structure of a central New York shrub-carr 94 years after fire. Bulletin of the Torrey Botanical Club 119(1):50-64.

449. Lehnen, L. P. and M. J. Powell.

1988. Topographic and fire effects on the composition and abundance of VA-mycorrhizal fungi in tallgrass prairie. Mycologia 80(4):423-32.

450. Leitner, L. A., C. P. Dunn, G. R. Guntenspergen, F. Stearns, and D. M. Sharpe.

1991. Effects of site, landscape features, and fire regime on vegetation patterns in presettlement southern Wisconsin. Landscape Ecology 5(4):203-17. 
451. Lemon, P. C.

1949. Successional responses of herbs in longleaf-slash pine forest after fire. Ecology 30:135-45.

452. Lewis, C. E. and T. J. Harshbarger.

1986. Burning and grazing effects on bobwhite foods in the southeastern coastal plain. Wildlife Society Bulletin 14(4):455-59.

453. Lewis, H. T

1980. Indian fires of spring. Natural History 89(1):76-83.

454. Lindesay, J. A.

1992. Biomass burning as a factor in atmospheric chemistry and terrestrial ecology: an introduction to the Igac Stare Southern African Fire Atmosphere Research Initiative (Safari). South African Journal of Science 88(3):143-44.

455. Little, S.

1964. Fire ecology and forest management in the New Jersey pine region. Proceedings. Tall Timbers Fire Ecology Conference 3:35-59.

456. Little, S.

1974. Effects of fire on temperate forests: northeastern United States. pp. 225-50 in T. T. Kozlowski and C. E. Ahlgren, eds. Fire and ecosystems. Academic Press, New York. 542 pp.

457. Little, S. N. and J. L. Ohmann

1988. Estimating nitrogen lost from forest floor during prescribed fires in douglas-fir/western hemlock clearcuts. Forest Science 34(1):152-64.

458. Lochmiller, R. L., J. F. Boggs, S. T. McMurry,

D. M. Leslie, and D. M. Engle.

1991. Response of cottontail rabbit populations to herbicide and fire applications on Cross Timbers Rangeland. Journal of Range Management 44(2):150-55.

459. Loiselle, B. A. and J. G. Blake.

1984. Site tenacity of birds on Curtis Prairie, Dane County, Wisconsin. Passenger Pigeon 46(1):16-21.

460. Longstreth, D. J. and D. T. Pattern.

1975. Conversion of chaparral to grass in central Arizona: effects on selected ions in watershed runoff. American Midland Naturalist 93:25-34.

461. Loomis, R. M.

1973. Estimating fire-caused mortality and injury in oak-hickory forests. U.S. Department of Agriculture Forest Service Research Paper NC-94. 6 pp.

462. Loomis, R. M.

1974. Predicting the losses in sawtimber volume and quality from fires in oak-hickory forests. U.S. Department of Agriculture Forest Service Research Paper NC-104. 6 pp.
463. Loomis, R.. M.

1977. Wildfire effects on an oak-hickory forest in southeast Missouri. USDA Forest Service Research Note NC-219. 4 pp.

464. Loope, W. L

1991. Interrelationships of fire history, land use history, and landscape pattern within Pictured Rocks National Lakeshore, Michigan (USA). Canadian-Field Naturalist 105(1):18-28.

465. Lorimer, C. G.

1986. The role of fire in the perpetuation of oak forests. pp. 8-25 in J. E. Johnson, ed. Proceedings of Challenges in Oak Management and Utilization Conference, 28-29 March 1985. University of Wisconsin Extension Service, Madison. 161 pp.

466. Lorimer, C. G.

1989. The oak regeneration problem: new evidence on causes and possible solutions. Forest Resource Analyses 8:1-31.

467. Lorimer, C. G. and W. R. Gough.

1988. Frequency of drought and severe fire weather in north- eastern Wisconsin. Journal of Environmental Management 26(3):203-20.

468. Lotan, J. E. and J. K. Brown

1985. Fire's effect on wildlife habitat. U.S. Department of Agriculture Forest Service General Technical Report INT-186. 96 pp.

469. Lovell, D. L., R. A. Henderson, and E. A. Howell.

1983. The response of forb species to seasonal timing of prescribed burns in remnant Wisconsin prairies. pp. 7-10 in R. Brewer, ed. Proceedings of the 8th North American Prairie Conference. Western Michigan University, Kalamazoo. 175 pp.

470. Lussenhop, J. F.

1971. Response of a prairie soil arthropod population to burning. University of Wisconsin-Madison. Ph.D. Thesis. $100 \mathrm{pp}$

471. Lussenhop, J. F.

1976. Soil arthropod response to prairie burning. Ecology 57:88-98.

472. Lyon, L. J., H. S. Crawford, E. Czuhai, R. L. Fredriksen, R. F. Harlow, L. J. Metz, and H. A. Pearson.

1978. Effects of fire on fauna. U.S. Forest Service General Technical Report WO-6. 41 pp.

473. MacCracken, J. G. and L. A. Viereck.

1990. Browse regrowth and use by moose after fire in interior Alaska. Northwest Science 64(1):11-18. 
474. Malin, J. C.

1953. Soil, animal, and plant relations of the grasslands historically reconsidered. Science Monthly 76:207-20.

475. Manfredo, M. J., M. Fishbein, G. E. Haas, and A. Watson.

1990. Attitudes toward prescribed fire policies. Journal of Forestry 88(7):19-23.

476. Markalas, S.

1991. Insects attacking burnt pine trees (Pinus halepensis, Pinus brutia and Pinus nigra) in Greece. Anzeiger Fuer Schaedlingskunde Pflanzerschutz Umweltschutz 64(4):72-5.

477. Martin, C.

1973. Fire and forest structure in the aboriginal eastern forest. The Indian Historian 6(3):23-26.

478. Martin, R. E.

1963. A basic approach to fire injury of tree stems. Proceedings Tall Timbers Fire Ecology Conference 2:151-62.

479. Martin, R. E., H. E. Anderson, W. D. Boyer, J. H. Dieterich, S. N. Hirsch, V. J. Johnson, and W. H. McNab.

1979. Effects of fire on fuels. U.S. Department of Agriculture Forest Service General Technical Report WO-13. 64 pp.

480. Martin, R. E. and C. T. Cushwa.

1966. Effects of heat and moisture on leguminous seed. Proceedings Tall Timbers Fire Ecology Conference 5:159-75.

481. Martin, R. E., C. T. Cushwa, and R. L. Miller.

1969. Fire as a physical factor in wildland management. Proceedings Tall Timbers Fire Ecology Conference 9:271-88.

482. Mason, A. C.

1985. Black bear damage in thinned and natural 1931 wildfire origin stands in northwest Montana. University of Idaho. M.S. Thesis. 106 pp.

483. Masters, R. A., R. B. Mitchell, K. P. Vogel, and S. S. Waller.

1993. Influence of improvement practices on big bluestem and indian-grass seed production in tallgrass prairies. Journal of Range Management 46(2):183-88.

484. Masters, R. A., K. P. Vogel, and R. B. Mitchell.

1992. Response of central plains tallgrass prairies to fire, fertilizer, and atrazine. Journal of Range Management 45(3):291-95.
485. Mather, T. N., D. C. Duffy, and S. R. Campbell.

1993. An unexpected result from burning vegetation to reduce lyme disease transmission risks. Journal of Medical Entomology 30(3):642-45.

486. Mathews, E., L. Lavdas, L. Mahaffey, T. Nichols, D. Sandberg, and M. Zlolko.

1985. Smoke management. Chapter III, pp. 11-18 in Prescribed Fire and Fire Effects Working Team. Prescribed fire: smoke management guide. U.S. Department of Agriculture, National Wildfire Coordinating Group, Washington, D.C. 28 pp.

487. Matlack, G. R., D. J. Gibson, and R. E. Good.

1993. Regeneration of the Shrub Gaylussacia baccata and associated species after low-intensity fire in an Atlantic coastal plain forest. American Journal of Botany 80(2):119-26.

488. Matlack, G. R. and R. E. Good.

1989. Plant scale pattern among herbs and shrubs of a fire dominated coastal plain forest. Vegetation 82(2):95-104.

489. Matlack, G. R. and R. E. Good.

1990. Spatial heterogeneity in the soil seed bank of a mature coastal plain forest. Bulletin of the Torrey Botanical Club 117(2):143-52.

490. McAlpine, R. S.

1989. Temporal variations in elliptical forest fire shapes. Canadian Journal of Forest Research 19(11):1496-1500.

491. McCabe, T. L

1981. The Dakota skipper, Hesperia dacotae: range and biology with special reference to North Dakota. Journal of the Lepidopterist's Society 35:179-93.

492. McClain, W. E., M. A. Jenkins, S. E. Jenkins, and J. E. Ebinger.

1993. Changes in the woody vegetation of a bur oak savanna remnant in central Illinois. Natural Areas Journal 13(2):108-14.

493. McClaran, M. P.

1988. Comparison of fire history estimates between open-scarred and intact Quercus douglasii. American Midland Naturalist 120(2):432-35.

494. McCoy, E. D. and B. W. Kaiser.

1990. Changes in foraging activity of the southern harvester ant Pogonomyrmex badius (Latreille) in response to fire. American Midland Naturalist 123(1):112-23

495. McCullough, D. G. and H. M. Kulman.

1991. Differences in foliage quality of young jack pine (Pinus Banksiana Lamb) on burned and clearcut sites: effects on jack pine budworm (Choristoneura pinus pinus Freeman). Oecologia 87(1):135-45. 
496. McGinley, M. A. and D. Tilman.

1993. Short-term response of old-field plant communities to fire and disturbance. American Midland Naturalist 129(2):409-13.

497. Mcllvain, E. H. and C. G. Armstrong.

1966. A summary of fire and forage research on shinnery oak rangelands. Proceedings Tall Timbers Fire Ecology Conference 5:127-29.

498. McMurphy, W. E. and K. L. Anderson.

1963. Burning bluestem range-forage yields. Transactions of the Kansas Academy of Science 66:49-51.

499. McMurphy, W. E. and K. L. Anderson.

1965. Burning Flint Hills range. Journal of Range Management 18:265-69.

500. McNabb, D. H., F. Gaweda, and H. A. Froelich.

1989. Infiltration, water repellency, and soil moisture content after broadcast burning a forest site in southwest Oregon. Journal of Soil and Water Conservation 44(1):87-90.

501. McPherson, G. R., G. A. Rasmussen, H. A. Wright, and C. M. Britton.

1986. Getting started in prescribed burning. Management Notes 9. Texas Tech University, Department of Range and Wildlife Management, Lubbock, Texas. 5 pp.

502. McSorley, R.

1993. Short-term effect of fire on the nematode community in a pine forest. Pedobiologia 37(1):39-48.

503. Means, D. B. and H. W. Campbell.

1981. Effects of prescribed burning on amphibians and reptiles. pp. 89-96 in G. W. Woods, ed. Prescribed fire and wildlife in southern forests symposium proceedings. Clemson University, Georgetown, South Carolina. 153 pp.

504. Medve, R. J.

1985. The effect of fire on the root hairs and mycorrhizae of Liatris spicata. Ohio Journal of Science 85(4):151-54.

505. Medve, R. J.

1987. The effects of fire on resource allocation and growth of Liatrus spicata. American Midland Naturalist 117(1):199-203.

506. Melgoza, G., R. S. Novak, and R. J. Tausch.

1990. Soil water exploitation after fire-competition between Bromus tectorum (cheatgrass) and two native grasses. Oecologia 83(1):7-13.

507. Miller, H. A.

1963. Use of fire in wildlife management. Proceedings Tall Timbers Fire Ecology Conference 2:19-30.
508. Miller, W. E.

1979. Fire as an insect management tool. Entomological Society of America 25(2):137-40.

509. Miyanishi, K. and M. Kellman.

1988. Ecological and simulation studies of the response of Miconia albicans and Clidemia sericea populations to prescribed burning. Forest Ecology Management 23:121-38.

510. Mooney, H. A., T. M. Bonniksen, N. L. Christensen, J. E. Lotan, and W. A. Reiners.

1981. Fire regimes and ecosystem properties. U.S. Department of Agriculture Forest Service General Technical Report WO-26. 593 pp.

511. Moore, C. T.

1972. Man and fire in central North American grassland 1535-1890: a documentary historical geography. University of California-Los Angeles. Ph. D. Thesis. 155 pp.

512. Moore, P. D.

1989. Paleoenvironments: no smoke without fire. Nature 342(6247):226.

513. Moreno, J. M. and W. C. Oechel.

1991. Fire intensity effects on germination of shrubs and herbs in Southern California chaparral. Ecology 72(6):1993-2004.

514. Mount, A. B.

1969. An Australian's impression of North American attitudes to fire. Proceedings Tall Timbers Fire Ecology Conference 9:109-18.

515. Mushinsky, H. R

1985. Fire and the Florida sandhill herpetofaunal community: with special attention to responses of Cnemidophorus sexlineatus. Herpetologica 41(3):333-41.

516. Mushinsky, H. R

1986. Fire vegetation structure and herpetofaunal communities. pp. 383-85 in R. Zybynek, ed. Studies in herpetology. Charle University, Prague. 754 pp.

517. Mushinsky, H. R.

1992. Natural history and abundance of southeastern 5-lined skinks, Eumeces inexpectatus, on a periodically burned sandhill in Florida. Herpetologica 48(3):307-12.

518. Mushinsky, H. R. and D. J. Gibson.

1991. The influence of fire periodicity on habitat structure. pp. 236-59 in S. S. Bell, E. D. McCoy, and H. R. Mushinsky, eds. Habitat structure: the physical arrangement of objects in space. Chapman and Hall, New York. 483 pp. 
519. Mutch, R. W.

1970. Wildland fires and ecosystems: a hypothesis. Ecology 51(6):1046-51.

520. Nagel, H. G.

1973. Effect of spring burning on herbivorous arthropod populations. Journal of the Kansas Entomological Society 46:485-96.

521. Nagel, H. G.

1980. Effect of spring burning date on mixed-prairie soil moisture, productivity and plant species composition. pp. 259-64 in C. L. Kucera, ed. Proceedings of the 7th North American Prairie Conference. Southwest Missouri State University, Springfield. 321 pp.

522. Neel, L.

1967. Wildlife forestry and fire. Proceedings Tall Timbers Fire Ecology Conference 6:21-27.

523. Nelson, J. F. and R. H. Dictz.

1966. Cattail control methods in Utah. Utah Department of Fish and Game Publication No. 66-2. $33 \mathrm{pp}$.

524. Netherland, L.

1979. The effect of disturbances in tallgrass prairie sites on an index of diversity and equitability. Southwestern Naturalist 24(2):267-74.

525. Nicolai, V.

1991. Reactions of the fauna on the bark of trees to the frequency of fires in a North American savanna. Oecologia 88(1):132-37.

526. Niemi, G. J.

1978. Breeding birds of burned and unburned areas in northern Minnesota. Loon 50:73-84.

527. Niemi, G. J. and J. R. Probst.

1990. Wildlife and fire in the upper midwest. pp. 3146 in J. Sweeny, ed. Management of dynamic ecosystems. The Wildlife Society, North Central Section, West LaFayette, Indiana. 180 pp.

528. Niering, W. A. and G. D. Dreyer.

1989. Effects of prescribed burning on Schizachyrium scoparium in post-agricultural grasslands in Connecticut. American Midland Naturalist 122(1):88-102.

529. Niering, W. A., R. H. Goodwin, and S. Taylor.

1970. Prescribed burning in southern New England: introduction to long-range studies. Proceedings Tall Timbers Fire Ecology Conference 10:267-86.

530. Nuzzo, V. A.

1991. Experimental control of garlic mustard (Alliaria petiolata (Bieb.) Cavara and Grande) in northern Illinois (USA) using fire, herbicide, and cutting. Natural Areas Journal 11(3):158-67.
531. Nyland, R. D., L. P. Abrahamson, and K. B. Adams. 1982. Use of prescribed fire for regenerating red and white oak in New York. pp. 163-67 in America's hardwood forests: opportunities unlimited. Proceedings of the Society of American Foresters National Convention, Washington, D.C. $352 \mathrm{pp}$.

532. Odum, E. P., S. E. Pomeroy, J. C. Dickinson, and $\mathrm{K}$. Hutcheson.

1974. The effects of late winter litter burn on the composition, productivity and diversity of a 4year old fallow-field in Georgia. Proceedings Tall Timbers Fire Ecology Conference 13:399-419.

533. Ojima, D. S., W. J. Parton, D. S. Schimel, and C. E. Owensby.

1990. Simulated impacts of annual burning on prairie ecosystems. pp. 118-32 in S. L. Collins and L. L. Wallace, eds. Fire in North American tallgrass prairies. University of Oklahoma Press, Norman. $175 \mathrm{pp}$.

534. Okano, S.

1990. Availability of mineralized-N from microbial biomass and organic matter after drying and heating of grassland soils. Plant and Soil 129(2):219-25.

535. Old, S. M.

1969. Microclimate, fire, and plant production in an Illinois prairie. Ecological Monographs 39(4):355-84.

536. Olson, D. P. and R. R. Weyrick.

1987. White pine management with prescribed fire. New Hampshire Agricultural Experiment Station Research Report 113:1-15.

537. Olson, W. W.

1975. Effects of controlled burning on grassland within the Tewaukon National Wildlife Refuge. North Dakota State University-Fargo. M. S. Thesis. $137 \mathrm{pp}$.

538. Omi, P. N.

1990. History of wildland burning in America from an air quality perspective. pp. 2-6 in The 83rd Annual Meeting and Exhibition of the Air and Waste Management Association. Pittsburgh, Pennsylvania, 24-29 June 1990.

539. Opler, P. A.

1981. Management of prairie habitats for insect conservation. Journal of the Natural Areas Association 1(4):3-6.

540. Orme, M. L. and T. A. Leege.

1974. Emergence and survival of redstem (Ceanothus sanguineus) following prescribed burning. Proceedings Tall Timbers Fire Ecology Conference 14:391-420. 
541. Overpeck, J. T.

1992. Fire alarm? [Review of Global biomass burning: atmospheric, climatic, and biospheric implications, J. S. Levine, ed.] Nature 356(6371):670.

542. Owensby, C. E. and K. L. Anderson.

1967. Yield response to time of burning in the Kansas Flint Hills. Journal of Range Management 20:12-16.

543. Owensby, C. E. and E. F. Smith.

1973. Burning true prairie. pp. 1-4 in L. C. Hulbert, ed. Proceedings of the 3rd Midwest Prairie Conference. Kansas State University, Division of Biology, Manhattan. 91 pp.

544. Owensby, C. E. and J. B. Wyrill.

1973. Effects of range burning on Kansas Flint Hills soil. Journal of Range Management 26:185-88.

545. Pack, J. C., W. K. Igo, and C. I. Taylor.

1988. Use of prescribed burning in conjunction with thinning to increase wild turkey brood habitat in oak-hickory forest. Transactions of the Northeast Section the Wildlife Society 45:37-48.

546. Packard, $\mathrm{S}$

1988. Management and restoration of prairie groves. Paper presented at Oak Woods Management Workshop, Peoria, Illinois.

547. Palik, B. J. and K. S. Pregitzer.

1992. A comparison of presettlement and present-day forests on 2 bigtooth aspen-dominated landscapes in northern lower Michigan. American Midland Naturalist 127(2):327-38.

548. Panzer, $R$.

1988. Managing prairie remnants for insect conservation. Natural Areas Journal 8(2):83-90.

549. Papike, R. V.

1984. Experimental burns, re-introductions in savanna restoration project. Restoration and Management Notes 2(2):73.

550. Parmeter, J. R. and B. Uhrenholdt.

1974. Effects of smoke on pathogens and other fungi. Proceedings Tall Timbers Fire Ecology Conference 14:299-304.

551. Parsons, D. J. and D. M. Graber.

1986. Natural fire management in national parks. Environmental Management 10(1):21-4.

552. Patterson, W. A. and A. E. Backman.

1988. Fire and disease history of forests. Vegetation History 7:603-32.
553. Patterson, W. A. and K. E. Sassaman

1988. Indian fires in the prehistory of New England. pp. 107-35 in G. P. Nicholas, ed. Holocene human ecology in northeastern North America. Plenum Press, New York. 319 pp.

554. Payette, S., L. Filion, and A. Delwaide.

1990. Disturbance regime of a cold temperate forest as deduced from tree-ring patterns: the Tantare Ecological Reserve, Quebec. Canadian Journal of Forest Research 20(8):1228-41.

555. Payette, S., C. Morneau, L. Sirois, and M. Desponts. 1989. Recent fire history of the northern Quebec (Canada) biomes. Ecology 70(3):656-73.

556. Pearse, A. S.

1943. Effects of burning over and raking off litter on certain soil animals in the Duke Forest. American Midland Naturalist 29:406-24.

557. Pearson, J.

1992. Sheeder Prairie: a people pasture. Iowa Conservationist 51(7):55-57.

558. Peck, V. R. and J. M. Peek.

1991. Elk, Cervus elaphus, habitat use related to prescribed fire, Tuchodi River, British-Columbia. Canadian Field Naturalist 105(3):354-62.

559. Peek, J. M.

1986. A review of wildlife management. Prentice-Hall, New Jersey. 486 pp.

560. Peet, M., R. Anderson, and M. Adams.

1975. Effect of fire on big bluestem production. American Midland Naturalist 94:15-26.

561. Peet, M. M.

1972. The effect of burning on microclimate and production in Wisconsin tall-grass prairie. University of Wisconsin, Madison. M. S. Thesis. 125 pp.

562. Pemble, R. H., VanAmburg. G.L., and L. Mattson.

1981. Intraspecific variation in flowering activity following a spring burn on a northwestern Minnesota prairie. pp. 235-40 in R. L. Stuckey and K. J. Reese, eds. Proceedings of the 6th North American Prairie Conference. College of Biological Sciences, Ohio State University, Columbus. 278 pp.

563. Penfound, W. T. and E. S. Hathawasy

1938. Plant communities in the marshlands of southeastern Louisiana. Ecological Monographs 8:1-56.

564. Penfound, W. T. and R. W. Kelting.

1950. Some effects of winter burning on a moderately grazed pasture. Ecology 31:554-60. 
565. Perala, D. A.

1974. Growth and survival of northern hardwood sprouts after burning. U.S. Department of Agriculture Forest Service Research Note NC176. $4 \mathrm{pp}$.

566. Petersen, K. L. and L. B. Best.

1987. Effects of prescribed burning on nongame birds in a sagebrush community. Wildlife Society Bulletin 15:317-19.

567. Peterson, D. L. and M. J. Arbaugh.

1986. Postfire survival in douglas-fir and lodgepole pine: comparing the effects of crown and bole damage. Canadian Journal of Forest Research 16(6):1175-79.

568. Peterson, J. L.

1988. Using NRDRS-predicted 1000-hour fuel moisture as a daily management tool. Fire Management Notes 49(4):9-12.

569. Peterson, S. K., G. A. Kaufman, and D. W. Kaufman.

1985. Habitat selection by small mammals of the tallgrass prairie: experimental patch choice. Prairie Naturalist 17(2):65-70.

570. Pivello, V. R. and L. M. Coutinho.

1992. Transfer of macro-nutrients to the atmosphere during experimental burnings in an open cerrado (Brazilian savanna). Journal of Tropical Ecology 8(Part 4):487-97.

571. Platt, W. J., G. W. Evans, and M. M. Davis.

1988. Effects of fire season on flowering of forbs and shrubs in longleaf pine forests. Oecologia 76(3):353-63.

572. Post, T. W. and K. F. Klick.

1988. One-year study of fire effects on Rhamnus frangula. Natural Areas Journal 8(2):120-21.

573. Prachar, R., Jr. R. W. Sage, and M. S. Deisch.

1988. Site occupancy, density, and spatial distribution of beaver colonies in burned and unburned areas in the Adirondacks. Transactions of the Northeast Section of the Wildlife Society 45:74.

574. Probasco, G. E. and A. J. Bjugstad.

1977. Tall fescue response to fire. U.S. Department of Agriculture Forest Service Research Note NC-218. 3 pp.

575. Pylypec, B.

1991. Impacts of fire on bird populations in a fescue prairie. Canadian Field Naturalist 105(3):346-49.

576. Pyne, S. J.

1982. Fire in America: cultural history of wildland and rural fire. Princeton University Press, Princeton, New Jersey. 651 pp.
577. Pyne, S. J.

1983. Indian fires. Natural History 2:6-11.

578. Quick, C. R. and A. S. Quick.

1961. Germination of Ceanothus seeds. Madrono 16(1):23-30.

579. Quimby, G. I.

1960. Indian life on the upper Great Lakes, 11,000 B.C. to A.D. 1800 . University of Chicago Press. $182 \mathrm{pp}$

580. Quinn, M. A., R. L. Kepner, D. D. Walgenbach, R. A. Bohls, P. D. Pooler, R. N. Foster,

K. C. Reuter, and J. L. Swain.

1991. Habitat characteristics and grasshopper community dynamics on mixed-grass rangeland. Canadian Entomologist 123(1):89-105.

581. Radke, L. F., J. L. Smith, D. A. Hegg, and P. V. Hobbs.

1978. Airborne studies of particles and gases from forest fires. Journal of the Air Pollution Control Association 28(1):30-34.

582. Ream, C. H.

1981. The effects of fire and other disturbances (logging, grazing, spraying) on small mammals and their predators: an annotated bibliography. U.S. Department of Agriculture Forest Service General Technical Report INT-106.

583. Reaves, J. L., C. G. Shaw III, and J. E. Mayfield.

1990. The effects of Trichoderma spp. isolated from burned and non-burned forest soils on the growth and development of Armillaria ostoyae in culture. Northwest Science 64(1):39-44.

584. Rebertus, A. J., G. B. Williamson, and E. B. Moser. 1989. Fire induced changes in Quercus laevis spatial pattern in Florida (USA) sandhills. Journal of Ecology 77(3):638-50.

585. Rebertus, A. J., G. B. Williamson, and E. B. Moser.

1989. Longleaf pine pyrogenicity and turkey oak mortality in Florida (USA) xeric sandhills. Ecology 70(1):60-70.

586. Recher, H. F. and P. E. Christensen.

1981. Fire and the evolution of the Australia biota. pp. 135-62 in A. Keast, ed. Ecological biogeography of Australia. W. Junk, Boston, Massachusetts. 2142 pp.

587. Redmann, R. E.

1978. Plant and soil water potentials following fire in a northern mixed grassland. Journal of Range Management 31:443-45. 
588. Rego, F. and E. Rigolot.

1990. Heat transfer through bark: a simple predictive model. pp. 157-61 in J. G. Goldrammer and M. J. Jenkins, eds. Fire in ecosystem dynamics: Mediterranean and northern perspectives. SPB Academic Publishing bv, The Hague, Netherlands. $199 \mathrm{pp}$.

589. Reich, P. B., M. D. Abrams, D. S. Ellsworth, E. L. Kruger, and T. J. Tabone.

1990. Fire affects, ecophysiology and community dynamics of central Wisconsin oak forest regeneration. Ecology 71(6):2179-90.

590. Reich, P. B., M. D. Abrams, D. S. Ellsworth, E. L. Kruger, and T. J. Tabone.

1989. Ecophysiology of competing woody species in burned and unburned oak forest gaps in central Wisconsin. Bulletin of the Ecological Society of America 70(2):238

591. Reifsnyder, W. E.

1970. Weather and fire control. Proceedings Tall Timbers Fire Ecology Conference 10:115-27.

592. Reinhardt, E. D. and K. C. Ryan.

1988. How to estimate tree mortality resulting from underburning. Fire Management Notes 49(4):30-36.

593. Reinhardt, E., A. H. Wright, and D. H. Jackson.

1989. An advisory expert system for designing fire prescriptions. Ecological Modelling 46:121-33.

594. Renwald, J. D.

1977. Effect of fire on lark sparrow nesting density. Journal of Range Management 30:283-85.

595. Rice, E. L. and R. L. Parenti.

1978. Causes of decreases in productivity in undisturbed tallgrass prairie. American Journal of Botany 65:1091-97.

596. Rice, L. A.

1932. The effect of fire on the prairie animal communities. Ecology 13:392-401.

597. Richards, M. S. and R. Q. Landers.

1973. Responses of species in Kalsow Prairie, Iowa, to an April fire. Proceedings of the Iowa Academy of Science 80:159-61.

598. Riechert, S. E. and W. G. Reeder.

1972. Effects of fire on spider distribution in southwestern Wisconsin prairies. pp. 73-90 in J. Zimmerman, ed. Proceedings of the 2nd Midwest Prairie Conference. J. H. Zimmerman, Madison, Wisconsin. 242 pp.
599. Risser, P. G.

1990. Landscape processes and the vegetation of the North American grassland. pp. 131-46 in S. L. Collins and L. L. Wallace, eds. Fire in North American tallgrass prairies. University of Oklahoma Press, Norman. 175 pp.

600. Risser, P. G., E. C. Birney, H. D. Blocker,

S. W. May, W. J. Parton, and J. A. Wiens.

1981. Ecosystem responses to stresses. Chapter 10 pp. 405-32 in The true prairie ecosystem. US/IBP Synthesis Series 16. Hutchinson Ross Publishing Co., Stroudsburg, Pennsylvania.

601. Roberts, T. A. and R. L. Tiller.

1985. Mule deer and cattle response to a prescribed burn. Wildlife Society Bulletin 13(3):248-52.

602. Robock, A.

1988. Enhancement of surface cooling due to forest fire smoke. Science 242(4880):911-12.

603. Robocker, W. C. and B. J. Miller.

1955. Effect of clipping, burning, and competition on establishment and survival of some native grasses in Wisconsin. Journal of Range Management 8:117-20.

604. Roburg, T. R. and D. C. Glenn-Lewin.

1992. Effects of fire and atrazine on pasture and remnant prairie plant species in southern Iowa. pp. 107-12 in D. D. Smith and C. A. Jacobs, eds. Proceedings of the 12th North American Prairie Conference. University of Northern Iowa, Cedar Falls. 218 pp.

605. Rogers, D. J.

1959. Some effects of fire in'southern Wisconsin woodlots. University of Wisconsin Forest Research Notes 51. 2 pp.

606. Rogers, R.

1983. Ruffed grouse brood use of oak-hickory forests managed with prescribed burning. West Virginia University. M.S. Thesis. 113 pp.

607. Rogers, R. E

1985. Feeding activity of wild turkey poults in prescribed burned and thinned oak-hickory forests. Transactions of the Northeast Section the Wildlife Society 42:167-77.

608. Rogers, R. E. and D. E. Samuel.

1984. Ruffed grouse brood use of oak-hickory managed with prescribed burning. Transactions of the Northeast Section the Wildlife Society 41:142-54. 
609. Romo, J. T., P. L. Grilz, R. E. Redmann, and E. A. Driver.

1993. Standing crop, biomass allocation patterns and soil-plant water relations in Symphoricarpos occidentalis Hook - following autumn or spring burning. American Midland Naturalist 130(1):106-15.

610. Rossoll, $\mathrm{H}$.

1956. Controlled burning: using fire wisely. The Florida Forest Service, Tallahassee. $11 \mathrm{pp}$.

611. Rothermel, R. C.

1991. Predicting behavior of the 1988 Yellowstone fires: projections versus reality. International Journal of Wildland Fire 1(1):1-10.

612. Rouse, $\mathrm{C}$.

1986. Fire effects in northeastern forest: oak. U.S. Department of Agriculture Forest Service General Technical Report NC-105. 7 pp.

613. Rouse, $\mathrm{C}$.

1986. Fire effects in northeastern forests: jack pine. U.S. Department of Agriculture Forest Service General Technical Report NC-106. 8 pp.

614. Rouse, C.

1988. Fire effects in northeastern forests: red pine. U.S. Department of Agriculture Forest Service General Technical Report NC-129. 9 pp.

615. Rowley, I. and M. Brookey.

1987. The response of a small insectivorous bird to fire in heathlands. pp. 211-18 in D. Saunders, G. Arnold, A. Burbridge, and A. Hopkins, eds. Nature conservation: the role of remnants of native vegetation. Surrey Beatty and Sons, Chipping Norton, Australia. 410 pp.

616. Rundel, P. W.

1981. Fire as an ecological factor. pp. 501-28 in D. L. Lange, P. S. Nobel, C. B. Osmond and H. Ziegler, eds. Physiological Plant Ecology. SpringerVerlag, New York. 625 pp.

617. Russell, E. W. B.

1983. Indian-set fires in the forests of the northeastern U.S. Ecology 64:74-88.

618. Ruyle, G. B., B. A. Roundy and J. R. Cox.

1988. Effects of burning on germinability of lehmann lovegrass. Journal of Range Management 41(5):404-06.

619. Ryan, M. R.

1986. Nongame management in grassland and agricultural ecosystems. pp. 117-36 in J. B. Hale, L. B. Best, and R. L. Clawson, eds. Management of nongame wildlife in the midwest: a developing art. The Wildlife Society, Madison, Wisconsin. $171 \mathrm{pp}$.
620. Sabiiti, E. N. and R. W. Wein.

1987. Fire and Acacia seeds: a hypothesis of colonization success. Journal of Ecology 75(4):937-46.

621. Sandberg, D. V., J. M. Piervich, D. G. Fox, and E. W. Ross

1979. Effects of fire on air. U.S. Department of Agriculture Forest Service General Technical Report WO-09. 40 pp.

622. Sanders, K. and J. Durham, eds.

1985. Rangeland fire effects: a symposium. U.S. Department of the Interior, Bureau of Land Management, Boise, Idaho. 124 pp.

623. Sando, R. W.

1967. The effects of repeated spring burning on the oak stands of the Cedar Creek Natural History Area. University of Minnesota. M. S. Thesis.

624. Sando, R. W.

1969. The current status of prescribed burning in the lake states. U.S. Department of Agriculture Forest Service Research Note NC-81. 2 pp.

625. Sando, R. W.

1971. A summary of prescribed burning done in the lake states during 1970. U.S. Department of Agriculture Forest Service Research Note NC125. $2 \mathrm{pp}$.

626. Sanhueza, E. and A. Rondon.

1988. Particle-size distribution of inorganic water soluble ions in the Venezuelan savannah atmosphere during burning and nonburning periods. Journal of Atmospheric Chemistry 7(4):369-88.

627. Sauer, C. O.

1950. Grassland climax, fire, and man. Journal of Range Management 3:16-21.

628. Sauer, R. H.

1978. Effect of removal of standing dead material on growth of Agropyron spicatum. Journal of Range Management 31:121-22.

629. Saveland, J. M. and L. F. Neuenschwander.

1990. A signal detection framework to evaluate models of tree mortality following fire damage. Forest Science 36(1):66-76.

630. Schaber, B. D. and T. Entz.

1988. Effect of spring burning on insects in seed alfalfa fields. Journal of Economic Entomology 81(2):668-72.

631. Schaber, B. D. and T. Entz.

1991. Effect of annual and or biennial burning of seed alfalfa stubble on populations of alfalfa weevil and pea aphid. Annals of Applied Biology 119(3):425-31. 
632. Schaefer, J. A. and W. O. Pruitt.

1991. Fire and woodland caribou in southeastern Manitoba (Canada). Wildlife Monographs 116:1-39.

633. Schaefer, V. J.

1974. Some physical relationships of fine particle smoke. Proceedings Tall Timbers Fire Ecology Conference 13:283-301.

634. Scheiner, S. M.

1988. Population dynamics of an herbaceous perennial Danthonia spicata during secondary forest succession. American Midland Naturalist 119(2):268-81.

635. Scheiner, S. M., T. L. Sharik, M. R. Roberts, and R. Vande Kopple.

1988. Tree density and modes of tree recruitment in a Michigan pine-hardwood forest after clearcutting and burning. Canadian-Field Naturalist 102(4):634-38.

636. Schlichtemeier, G.

1967. Marsh burning for waterfowl. Proceedings Tall Timbers Fire Ecology Conference 6:41-46.

637. Schmalzer, P. A., C. R. Hinkle, and J. L. Mailander. 1991. Changes in community composition and biomass in Juncus roemerianus Scheele and Spartina bakeri Merr marshes one year after a fire. Wetlands 11(1):67-86.

638. Schmalzer, P. A. and C. R. Hinkle.

1992. Soil dynamics following fire in Juncus and Spartina marshes. Wetlands 12(1):8-21.

639. Schramm, P.

1968. Effects of fire on small mammal populations in a restored tallgrass prairie. pp. 39-41 in P. Schramm, ed. Proceedings of a Symposium on Prairie and Prairie Restoration. Knox College, Galesburg, Illinois. 66 pp.

640. Schramm, P. and B. J. Willcutts.

1983. Habitat selection of small mammals in burned and unburned tallgrass prairie. pp. 49-55 in R. Brewer, ed. Proceedings of the 8th North American Prairie Conference. Western Michigan University, Kalamazoo. 175 pp.

641. Schwegman, J. E. and R. C. Anderson.

1984. Effect of eleven years of fires exclusion on the vegetation of a southern Illinois barren remnant. pp. $146-48$ in G. K. Clamby and R. H. Pemble, eds. Proceedings of the 9th North American Prairie Conference. Tricollege University Center for Environmental Studies, Fargo, North Dakota. 264 pp.
642. Schwegman, J. E. and W. E. McClain.

1985. Vegetative effects and management implications of a fall prescribed burn on an Illinois hill prairie. Natural Areas Journal 5(3):4-8.

643. Seastedt, T. R.

1984. Below ground macroarthropods of annually burned and unburned tallgrass prairie. American Midland Naturalist 111:405-08.

644. Seastedt, T. R.

1984. Microarthropods of burned and unburned tallgrass prairie. Journal of the Kansas Entomological Society 57(3):468-76.

645. Seastedt, T. R.

1985. Canopy interception of nitrogen in bulk precipitation by annually burned and unburned tallgrass prairie. Oecologia 66(1):88-92.

646. Seastedt, T. R.

1988. Mass, nitrogen, and phosphorus dynamics in foliage and root detritus of tallgrass prairie. Ecology 69(1):59-65.

647. Seastedt, T. R., J. M. Briggs, and D. J. Gibson.

1989. Fire frequency, plant productivity and nitrogen limitation in tallgrass prairie. Bulletin of the Ecological Society of America 70(2):259.

648. Seastedt, T. R., J. M. Briggs, and D. J. Gibson. 1991. Controls of nitrogen limitation in tallgrass prairie. Oecologia 87(1):72-79.

649. Seastedt, T. R. and A. K. Knapp.

1993. Consequences of nonequilibrium resource availability across multiple time scales: the transient maxima hypothesis. American Naturalist 141(4):621-33.

650. Seastedt, T. R. and R. A. Ramundo.

1990. The influence of fire on belowground processes of tallgrass prairie. pp. 99-117 in S. L. Collins and L. L. Wallace, eds. Fire in North American tallgrass prairies. University of Oklahoma Press, Norman. 175 pp.

651. Seastedt, T. R. and M. V. Reddy.

1991. Fire, mowing and insecticide effects on soil Sternorrhyncha (Homoptera) densities in tallgrass prairie. Journal of the Kansas Entomological Society 64(2):238-42.

652. Seitz, W. K.

1972. Controlled burning in relationship to bobwhite quail populations on the Mt. Ayr Game Management Area, Iowa. Iowa State University. M. S. Thesis. $150 \mathrm{pp}$.

653. Sgardelis, S. P. and N. S. Margaris.

1993. Effects of fire on soil microarthropods of a phryganic ecosystem. Pedobiologia 37(2):83-94. 
654. Shahlaee, A. K., W. L. Nutter, E. R. Burroughs, and L. A. Morris.

1991. Runoff and sediment production from burned forest sites in the Georgia Piedmont. Water Resources Bulletin 27(3):485-93.

655. Sharp, W. M.

1970. The role of fire in ruffed grouse habitat management. Proceedings Tall Timbers Fire Ecology Conference 10:47-61.

656. Shaw, J. H. and Carterm T.S.

1990. Bison movements in relation to fire and seasonality. Wildlife Society Bulletin 18(4):426-30.

657. Shirley, H. L.

1931. Does light stimulate aspen suckers? Journal of Forestry 30:419-20.

658. Simard, A. J.

1991. Fire severity, changing scales, and how things hang together. International Journal of Wildland Fire 1(1):23-34

659. Simard, A. J. and D. C. Baugartner.

1986. Predicting hardwood mortality following wildfires in the lake states. Michigan Academician 18(1):17-30.

660. Simard, A. J. and R. W. Blank.

1982. Fire history of a Michigan jack pine forest. Michigan Academician 15(1):59-71.

661. Simard, A. J., D. A. Haines, R. W. Blank, and J. S. Frost.

1983. The Mack Lake fire. U.S. Department of Agriculture Forest Service General Technical Report NC-83. $36 \mathrm{pp}$.

662. Singer, F. J., W. Schreier, J. Oppenheim, and E. O. Garten.

1989. Drought, fires and large mammals. BioScience 37(10):716-24.

663. Singh, R. S., A. S. Raghubanshi, and J. S. Singh.

1991. Nitrogen-mineralization in dry tropical savanna: effects of burning and grazing. Soil Biology \& Biochemistry 23(3):269-73.

664. Singh, R. S., S. C. Srivastava, A. S. Raghubanshi, J. S. Singh, and S. P. Singh.

1991. Microbial-C, microbial-N and microbial-P in dry tropical savanna: effects of burning and grazing. Journal of Applied Ecology 28(3):869-78.

665. Skarpe, C

1991. Impact of grazing in savanna ecosystems. Ambio 20(8):351-56.
666. Smith, D. W.

1968. Surface fires in northern Ontario. Proceedings Tall Timbers Fire Ecology Conference 8:41-54.

667. Smith, E. F. and C. E. Owensby.

1973. Effects of fire on true prairie grasslands. Proceedings Tall Timbers Fire Ecology Conference 12:9-22.

668. Smith, E. F. and V. A. Young

1959. The effect of burning on the chemical composition of little bluestem. Journal of Range Management 12:139-40.

669. Smith, J. K., R. D. Laven, and P. N. Omi.

1993. Microplot sampling of fire behavior on Populus tremuloides stands in north-central Colorado. International Journal of Wildland Fire 3(2):85-94.

670. Smith, K. G. and D. R. Petit.

1988. Breeding birds and forestry practices in the Ozarks: past, present, and future relationships. Bird Conservation 3:23-49.

671. Smith, L. M

1989. Effects of grazing and burning on nutritive quality of cattail in playas. Journal of Aquatic Plant Management 27:51.

672. Smith, L. M. and J. A. Kadlec.

1985. Fire and herbivory in a Great Salt Lake marsh. Ecology 66(1):259-65.

673. Smith, R. L.

1963. Some ecological notes on the grasshopper sparrow. Wilson Bulletin 75:159-65.

674. Sneewuwjagt, R. J. and W. H. Frandesen.

1977. Behavior of experimental fires vs. predictions based on Rothermel's fire model. Canadian Journal of Forest Research 7:357-67.

675. Snyder, E. J. and L. B. Best.

1988. Dynamics of habitat use by small mammals in prairie communities. American Midland Naturalist 119(1):128-36.

676. Solecki, M. K., J. B. Taft, E. A. Cook, and P. S. Haverland.

1986. Vegetational composition of three Missouri tallgrass prairies with reference to past management. Conservation Commission of the State of Missouri. 93 pp.

677. Speake, D. W.

1966. Effects of controlled burning on bobwhite quail populations and habitat of an experimental area in the Alabama piedmont. Proceedings of the Southeast Association Game and Fish Commission 20:19-32. 
678. Springer, J. T.

1988. Immediate effects of spring fire on small mammal populations in a Nebraska mixed-grass prairie. [var. pp.] in A. Davis and G. Stanford, eds. Proceedings of the 10th North American Prairie Conference. Native Prairie Association of Texas, Dallas. 334 pp.

679. Springer, J. T.

1988. Individual responses of some small mammals to a prairie fire. [var. pp.] in A. Davis and G. Stanford, eds. Proceedings of the 10th North American Prairie Conference. Native Prairie Association of Texas, Dallas. 334 pp.

680. Springer, J. T. and P. Schramm.

1970. The effects of fire on small mammal populations in a restored prairie with special reference to the short-tail shrew, Blarina brevicauda. pp. 91-96 in J. H. Zimmerman, ed. Proceedings of the 2nd Midwest Prairie Conference. J. H. Zimmerman, Madison, Wisconsin. 242 pp.

681. Sprugel, D. G.

1991. Disturbance, equilibrium, and environmental variability: what is natural vegetation in a changing environment. Biological Conservation 58(1):1-18.

682. St. Pierre, H., R. Gagnon, and P. Bellefleur.

1992. Regeneration following fire of the black spruce (Picea mariana) and the jack pine (Pinus banksiana) in the boreal forest of Quebec province. Canadian Journal of Forest Research 22(4):474-81.

683. St. Pierre, H., R. Gangon, and P. Bellefleur.

1991. Post fire spatial distribution of black spruce (Picea mariana) and jack pine (Pinus banksiana) in the boreal forest, Ashuapmushuan Wildlife Reserve, Quebec (Canada). Canadian Journal of Botany 69(4):717-21.

684. Stapanian, M. A. and C. C. Smith.

1986. How fox squirrels influence the invasion of prairies by nut-bearing trees. Journal of Mammalogy 67(2):326-32.

685. Stearns, F

1951. The composition of the sugar maple-hemlockyellow birch association in northern Wisconsin. Ecology 32:245-65.

686. Stensaas, $M$.

1989. Forest fire birding. Loon 61(1):43-4.

687. Stergas, R. L. and K. B. Adams.

1989. Jack pine barrens in northeastern New York (USA): Postfire macronutrient concentrations, heat content, and understory biomass. Canadian Journal of Forest Research 19(7):904-10.
688. Steuter, A. A.

1986. Fire behavior and standing crop characteristics on repeated seasonal burns: northern mixed prairie. pp. 54-59 in A. L. Koonce, ed. Prescribed burning in the midwest: state of the art. University of Wisconsin-Stevens Point. $162 \mathrm{pp}$.

689. Steuter, A. A.

1987. C3/C4 production shift on seasonal burns: northern mixed prairie. Journal of Range Management 40(1):27-31.

690. Steuter, A. A.

1988. Restoring a mixed prairie process: the firebison grazing interaction. Bulletin of the Ecological Society of America 69(2):308.

691. Steward, F. R., S. Peter, and J. B. Richon.

1990. A method for predicting the depth of lethal heat penetration into mineral soils exposed to fires of various intensities. Canadian Journal of Forest Research 20(7):919-20.

692. Stewart, O. C

1951. Burning and natural vegetation in the United States. Geographical Review 41:317-20.

693. Stewart, O. C.

1963. Barriers to understanding the influence of use of fire by aborigines on vegetation. Proceedings Tall Timbers Fire Ecology Conference 2:117-26.

694. Stinson, K. J. and H. A. Wright.

1969. Temperatures of headfires in the southern mixed prairie of Texas. Journal of Range Management 22:169-74.

695. Stith, J. L., L. F. Radke, and P. V. Hobbs.

1981. Particle emissions and the production of ozone and nitrogen oxides from the burning of forest slash. Atmospheric Environment 15:73-82.

696. Stock, A. J. and R. A. Gorley.

1989. Observations on a trial of broadcast burning to control an infestation of the mountain pine beetle Dendroctonus ponderosae. Canadian Entomologist 121(6):521-23.

697. Stocks, B. J.

1989. Fire behavior in mature jack pine. Canadian Journal of Forest Research 19(6):783-90.

698. Stoddard, H. L.

1962. Some techniques of controlled burnings in the deep southeast. Proceedings Tall Timbers Fire Ecology Conference 1:133-44. 
699. Stoddard, H. L.

1962. Use of fire in pine forests and game lands of the deep southeast. Proceedings Tall Timbers Fire Ecology Conference 1:31-42.

700. Stoddard, H. L.

1963. Bird habitat and fire. Proceedings Tall Timbers Fire Ecology Conference 2:163-75.

701. Stolzenburg, W.

1992. Through the eyes of butterflies, scientists are finding and mending flaws in the land. Nature Conservancy May/Jun:8-13.

702. Strauss, D., L. Bednar, and R. Mees.

1989. Do one percent of the forest fires cause ninetynine percent of the damage? Forest Science 35(2):319-28.

703. Stritzke, J. F., D. M. Engle, and F. T. McCollum.

1991. Vegetation management in the cross timbers: response of woody species to herbicides and burning. Weed Technology 5(2):400-05.

704. Strosnider, R. K.

1986. The role of fire in the Appalachian hardwoods. pp. 186-90 in D. Kulhavy and R. Conner, eds. Wilderness and natural areas in the eastern U.S.: a management challenge. Stephen F. Austin State University, Nacogdoches, Texas. 416 pp.

705. Stull, W. D.

1975. Spring burning effects on song birds. Ohio Department of Natural Resources. Final Report. Pittman-Robertson Project W-103-R-18.

706. Suffling, R., C. Lihou, and Y. Morand.

1988. Control of landscape diversity by catastrophic disturbance: a theory and a case study of fire in a Canadian boreal forest. Environmental Management 12(1):73-78.

707. Sumrall, L. B., B. A. Roundy, J. R. Cox, and V. K. Winkel.

1991. Influence of canopy removal by burning or clipping on emergence of Eragrostis lehmanniana seedlings. International Journal of Wildland Fire 1(1):35-40.

708. Sunquist, M. E.

1967. Effects of fire on raccoon behavior. Journal of Mammalogy 48:673-74.

709. Svedarsky, W. D. and P. E. Buckley.

1975. Some interactions of fire, prairie and aspen in northwest Minnesota. pp. 115-22 in M. K. Wali, ed. Prairie: a multiple view. University of North Dakota Press, Grand Forks. 433 pp.
710. Svedarsky, W. D., P. E. Buckley, and T. A. Feiro.

1986. The effect of 13 years of annual burning on an aspen-prairie ecotone in northwestern Minnesota. pp. 118-22 in G. K. Clambey and R. H. Pemble, eds. Proceedings of the 9 th North American Prairie Conference. Tri-College University Center for Environmental Studies, Moorehead, Minnesota. 264 pp.

711. Svejcar, T. J.

1989. Animal performance and diet as influenced by burning on tallgrass prairie. Journal of Range Management 42:115-22.

712. Svejcar, T. J.

1990. Response of Andropogon gerardii to fire in the tallgrass prairie. pp. 19-27 in S. L. Collins and L. L. Wallace, eds. Fire in North American tallgrass prairies. University of Oklahoma Press, Norman. 175 pp.

713. Swain, A. M.

1973. A history of fire and vegetation in northeastern Minnesota as recorded in lake sediments. Quaternary Research 3:383-96.

714. Swain, A. M.

1978. Environmental changes during the past 2000 years in north central Wisconsin: analysis of pollen, charcoal, and seeds from varved lake sediments. Quaternary Research 10:55-68.

715. Swain, A. M.

1980. Landscape patterns and forest history in the Boundary Waters Canoe Area, Minnesota: a pollen study from Hug Lake. Ecology 61(4):747-54.

716. Swan, F. R., Jr.

1970. Post-fire response of four plant communities in south central New York state. Ecology 51:1074-82.

717. Tan, Y. L., J. F. Quanci, R. D. Borys, and M. J. Quanci. 1992. Polycyclic aromatic hydrocarbons in smoke particles from wood and duff burning. Atmospheric Environment, Part A - General Topics 26(6):1177-81.

718. Tashiro, C., R. E. Clement, B. J. Stocks, L. Radke, W. R. Cofer, and P. Ward.

1990. Preliminary report: dioxins and furans in prescribed burns. Chemosphere 20(10-1):1533-36.

719. Tateishi, T., T. Horikoshi, H. Tsubota, and F. Takahashi.

1989. Application of the chloroform fumigation incubation method to the estimation of soil microbial biomass in burned and unburned Japanese red pine forests. FEMS Microbiology Ecology 62(3):163-72. 
720. Taylor, A. R.

1969. Lightning effects on the forest complex. Proceedings Tall Timbers Fire Ecology Conference 9:127-50.

721. Taylor, A. R.

1974. Ecological aspects of lightning in forests. Proceedings Tall Timbers Fire Ecology Conference 13:455-82.

722. Taylor, R. J.

1992. Fire, mycorrhizal fungi and management of mycophagous marsupials. Australian Journal of Ecology 17(2):227-28.

723. Tester, J. R.

1965. Effects of a controlled burn on small mammals in a Minnesota oak-savanna. American Midland Naturalist 74:240-43.

724. Tester, J. R.

1989. Effects of fire frequency on oak savanna in east-central Minnesota. Bulletin of the Torrey Botanical Club 116(2):134-44.

725. Thanos, C. A. and K. Georghiou.

1988. Ecophysiology of fire-stimulated seed germination in Cistus incanus ssp. creticus and C. salvifolius. Plant Cell and Environment 11(9):841-50.

726. Thill, R. E., A. Martin, H. F. Morris,

and E. D. McCune.

1987. Grazing and burning impacts on deer diets on Louisiana pine-bluestem range. Journal of Wildlife Management 51(4):873-80.

727. Thomas, P. A. and P. Goodson.

1992. Conservation of succulents in desert grasslands managed by fire. Biological Conservation 60(2):91-100.

728. Thomas, P. A. and R. W. Wein.

1990. Jack pine establishment on ash from wood and organic soil. Canadian Journal of Forest Research 20(12):1926-32.

729. Thompson, D. J. and J. M. Shay.

1989. First-year response of a Phragmites marsh community to seasonal burning. Canadian Journal of Botany 67(5):1448-55.

730. Thompson, D. Q. and R. H. Smith.

1970. The forest primeval in the Northeast: a great myth? Proceedings Tall Timbers Fire Ecology Conference 10:255-65.

731. Thompson, M. W., M. G. Shaw, R. W. Umber, J. E. Skeen, and R. E. Thackston.

1991. Effects of herbicides and burning on overstory defoliation and deer forage production. Wildlife Society Bulletin 19(2):163-70.
732. Thor, E. and G. M. Nichols.

1973. Some effects of fires on litter, soil, and hardwood regeneration. Proceedings Tall Timbers Fire Ecology Conference 13:317-29.

733. Tiedemann, A. R., C. E. Conrad, J. H. Dieterich, J. W. Hornbeck, W. F. Megahan, L. A. Viereck, and D. D. Wade.

1979. Effects of fire on water. U.S. Department of Agriculture Forest Service General Technical Report WO-10. 28 pp.

734. Towne, G. and C. Owensby.

1984. Long-term effects of annual burning at different dates in ungrazed Kansas tallgrass prairie. Journal of Range Management 37(5):392-97.

735. Trabaud, L

1990. Influence of fire on chemical properties in the upper layer of a garrigue soil. Revue d'Écologie et de Biologie du Sol 27(4):383-94.

736. Trabaud, L. and J. Oustric.

1989. Influence of fire on germination of 4 Mediterranean obligate seeder species. Seed Science and Technology 17(3):589-99.

737. Troumbis, A. Y. and L. Trabaud.

1989. Some questions about flammability in fire ecology. Acta Oecologia 10(2):167-76.

738. Tyndall, R. W. and P. M. Farr.

1989. Vegetation structure and flora of a serpentine pine cedar savanna in Maryland (USA). Castanea 54(3):191-99.

739. Ueckert, D. N., J. L. Petersen, and R. L. Potter 1988. Managing pricklypear with herbicides and fire. Texas Agricultural Experiment Station Progress Report 4570. 5 pp.

740. Uemura, S., S. Tsuda, and S. Hasegawa.

1990. Effects of fire on the vegetation of Siberian taiga predominated by Larix dahurica. Canadian Journal of Forest Research 20(5):547-53.

741. Urban, D.

1974. Burning frequency for rabbit management in Ohio. Ohio Department of Natural Resources Job Progress Report. Pittman-Robertson Proj. W-103-R-16. 25 pp.

742. U.S. Forest Service

1987. National forest fire report: 1986. U.S. Department of Agriculture, Forest Service, Washington, D.C. $33 \mathrm{pp}$.

743. Vacanti, P. L. and K. N. Geluso.

1985. Recolonization of a burned prairie by meadow voles (Microtus pennsylvanicus). Prairie Naturalist 17(1):15-22. 
744. Van Amburg, G. L., J. A. Swaby, and R. H. Pemble. 1981. Response of arthropods to a spring burn of a tallgrass prairie in northwestern Minnesota. pp. 240-43 in Stuckey, R. L. and K. J. Reese, eds. The prairie peninsula in the "shadow" of Transeau: Proceedings of the 6th North American Prairie Conference. Cólumbus, Ohio, 1217 August 1978.

745. Van Dyke, F. G., J. P. Dibenedetto, and S. C. Thomas. 1991. Vegetation and elk response to prescribed burning in south-central Montana. pp. 163-79 in R. B. Keiter and M. S. Boyce, eds. The greater Yellowstone ecosystem: redefining America's wilderness heritage. Yale University Press, New Haven, Connecticut. 428 pp.

746. Van Lear, D. H. and V. J. Johnson.

1983. Effects of prescribed burning in the Southern Appalachian and Upper Piedmont forests: a review. Clemson University Department of Forestry Forestry Bulletin No. 36. 8 pp.

747. Van Wagner, C. E.

1970. Fire and red pine. Proceedings Tall Timbers Fire Ecology Conference 10:211-19.

748. Van Wilgen, B. W. and A. J. Willis.

1988. Fire behavior prediction in savanna vegetation. South African Journal of Wildlife Research 18(2):41-46.

749. Vance, E. D. and G. S. Henderson.

1984. Soil nitrogen availability following long-term burning in an oak-hickory forest. Soil Science Society of America Journal 48:184-90.

750. Vanwagner, C. E.

1988. The historical pattern of annual burned area in Canada. Forestry Chronicle 64(3):182-85.

751. Verme, L. J. and W. F. Johnston.

1986. Regeneration of northern white cedar deeryards in Upper Michigan. Journal of Wildlife Management 50(2):307-13.

752. Vilarino, A. and J. Arines.

1991. Numbers and viability of vesicular-arbuscular fungal propagules in field soil samples after wildfire. Soil Biology \& Biochemistry 23(11):1083-87.

753. Vines, R. G.

1974. Bush-fire smoke and air quality. Proceedings Tall Timbers Fire Ecology Conference 13:303-07.

754. Vinton, M. A. and D. C. Hartnett.

1992. Effects of bison grazing on Andropogon gerardii and Panicum virgatum in burned and unburned tallgrass prairie. Oecologia 90(3):374-82.
755. Vinton, M. A., D. C. Hartnett, E. J. Finck, and J. M. Briggs.

1993. Interactive effects of fire, bison (Bison bison) grazing and plant community composition in tallgrass prairie. American Midland Naturalist 129(1):10-18.

756. Viro, P. J.

1974. Effects of forest fire on soil. pp. $7-45$ in T. T. Kozlowski and C. E. Ahlgren, eds. Fire and ecosystems. Academic Press, New York. 542 pp.

757. Vogl, R. J.

1961. The effects of fire on some upland vegetation types. University of Wisconsin-Madison. Ph. D. Thesis. $138 \mathrm{pp}$

758. Vogl, R. J.

1964. The effects of fire on the vegetational composition of bracken-grasslands. Transactions of the Wisconsin Academy of Sciences, Arts and Letters 53:67-82.

759. Vogl, R. J.

1964. The effects of fire on a muskeg in northern Wisconsin. Journal of Wildlife Management 28:317-29.

760. Vogl, R. J.

1964. Vegetational history of Crex Meadows, a prairie savanna in northwestern Wisconsin. American Midland Naturalist 72:157-75.

761. Vogl, R. J.

1965. Effects of spring burning on yields of brush prairie savanna. Journal of Range Management 18:202-05.

762. Vogl, R. J.

1967. Controlled burning for wildlife in Wisconsin. Proceedings Tall Timbers Fire Ecology Conference 6:47-96.

763. Vogl, R. J.

1969. One hundred and thirty years of plant succession in a southeastern Wisconsin lowland. Ecology 50(2):248-55.

764. Vogl, R. J.

1970. Fire and the northern Wisconsin pine barrens. Proceedings Tall Timbers Fire Ecology Conference 10:175-209.

765. Vogl, R. J.

1973. Effects of fire on the plants and animals of a Florida wetland. American Midland Naturalist 89:334-47.

766. Vogl, R. J.

1973. Fire in the southeastern grasslands. Proceedings Tall Timbers Fire Ecology Conference 12:175-98. 
767. Vogl, R. J,

1974. Effects of fire on grassland. pp. 139-94 in T. Kozlowski and C. Ahlgren, eds. Fire and ecosystems. Academic Press, New York, N.Y. 542 pp.

768. Vogl, R. J.

1977. Fire: a destructive menace or a natural process. pp. 260-62 in J. Cairns, K. C. Dickson, and E. E. Herricks, eds. Recovery and restoration of damaged ecosystems. University Virginia Press, Charlottesville. 531 pp.

769. Vogl, R. J.

1979. Some basic principles of grassland fire management. Environmental Management 3:51-57.

770. Vogl, R. J. and A. M. Beck.

1970. Response of white-tailed deer to a Wisconsin wildfire. American Midland Naturalist 84:270-73.

771. Vose, J. M. and A. S. White.

1987. Processes of understory seedling recruitment 1 year after prescribed fire in an Arizona ponderosa pine community. Canadian Journal of Botany 65(11):2280-90.

772. Wade, D. D. and J. D. Lunsford.

1988. A guide for prescribed fire in southern forests. U.S. Department of Agriculture Forest Service Southern Region R8-TP 11. 56 pp.

773. Wagle, R. F. and J. H. Kitchen, Jr.

1971. Influence of fire on soil nutrients in a ponderosa pine type. Ecology 53(1):118-25.

774. Waldrop, T. A., D. L. White, and S. M. Jones.

1992. Fire regimes for pine grassland communities in the southeastern United States. Forest Ecology and Management 47(1-4):195-210.

775. Wali, M. K., ed.

1975. Prairie: a multiple view. University of North Dakota Press, Grand Forks. 433 pp.

776. Wallace, F. L., M. A. Tidwell, D. C. Williams, and K. A. Jackson.

1990. Effects of controlled burning on Aedes taeniorhynchus eggs in an abandoned rice impoundment in South Carolina. Journal of the American Mosquito Control Association 6(3):528-29.

777. Ward, D. E. and C. C. Hardy.

1991. Smoke emissions from wildland fires. Environment International 17(2-3):117-34.

778. Ward, D. E. and R. C. Lamb.

1970. Prescribed burning and air quality: current research in the south. Proceedings Tall Timbers Fire Ecology Conference 10:129-40.
779. Ward, J. S. and G. R. Stephens.

1989. Long-term effects of a 1932 surface fire on stand structure in a Connecticut mixed-hardwoods forest. pp. 267-73 in G. Rink and C. A. Budelsky, eds. Proceedings of the 7th Central Hardwood Forest Conference. U.S. Department of Agriculture Forest Service General Technical Report NC-132. 313 pp.

780. Ward, P.

1968. Fire in relation to waterfowl habitat of the delta marshes. Proceedings Tall Timbers Fire Ecology Conference 8:255-67.

781. Warren, S. D., C. J. Scifres, and P. D. Teel.

1987. Response of grassland arthropods to burning: a review. Agriculture, Ecosystems and Environment 19:105-30.

782. Weaver, J. C.

1987. The effect of fire on the spider community of a native tallgrass prairie. University of Missouri. $\mathrm{Ph}$. D. Thesis.

783. Weaver, J. E. and N. W. Rowland.

1952. Effects of excessive natural mulch on development, yield, and structure of native grassland. Botanical Gazette 114:1-19.

784. Weber, M. G

1987. Decomposition, litter fall, and forest floor nutrient dynamics in relation to fire in eastern Ontario jack pine ecosystems. Canadian Journal of Forest Research 17(2):1496-1506.

785. Weber, M. G.

1990. Forest soil respiration after cutting and burning in immature aspen ecosystems. Forest Ecology Management 31:1-14.

786. Weber, M. G.

1990. Response of immature aspen ecosytems to cutting and burning in relation to vernal leaf-flush. Forest and Ecology Management 31:15-33.

787. Weber, M. G.

1990. Selected ecosystem processes in a Pinus resinosa Ait. forest in relation to other fire-affected eastern North American forest ecosystems. pp. 137-56 in J. G. Goldrammer and M. J. Jenkins, eds. Fire in ecosystem dynamics: Mediterranean and northern perspectives. SPB Academic Publishing bv, The Hague, Netherlands. 199 pp.

788. Weber, M. G.

1991. The effect of cutting and burning on browse production in eastern Canadian aspen forests. International Journal of Wildland Fire 1(1):41-48.

789. Wein, R. W. and D. A. McLean.

1983. The role of fire in northern circumpolar ecosystems. John Wiley and Sons, New York. 322 pp. 
790. Weller, M. W.

1975. Studies of cattail in relation to management for marsh wildlife. Iowa State Journal of Research 49(4):383-412.

791. Weller, M. W.

1979. Small-mammal populations and experimental burning of Dewey's pasture, northeast Iowa, 1970-1974. Iowa State Journal of Research 53(4):325-32.

792. Wells, C. G.

1979. Effects of fire on soil. U.S. Forest Service General Technical Report WO-7. 34 pp.

793. Wendel, G. W. and H. C. Smith.

1986. Effects of a prescribed fire in a central Appalachian oak-hickory stand. U.S. Department of Agriculture Forest Service Research Paper NE594. 8 pp.

794. Wendtland, K. J. and J. L. Dodd.

1992. The fire history of Scotts Bluff National Monument. pp. 141-44 in D. D. Smith and C. A. Jacobs, eds. Proceedings of the 12th North American Prairie Conference. University of Northern Iowa, Cedar Falls. 218 pp.

795. Westemeier, R. L.

1973. Prescribed burning in grassland management for prairie chickens in Illinois. Proceedings Tall Timbers Fire Ecology Conference 12:317-38.

796. Westemeier, R. L. and J. E. Buhnerkempe.

1983. Responses of nesting wildlife to prairie grass management on prairie chicken sanctuaries in Illinois. pp. 39-46 in Brewer, R., ed. Proceedings of the 8th North American Prairie Conference. Western Michigan University, Kalamazoo. 176 pp.

797. Westoby, M., B. Rice, G. Griffin, and M. Friedel.

1988. The soil seed bank of Triodia basedowii in relation to time since fire. Australian Journal of Ecology 13(2):161-70.

798. Wetmore, C. M.

1983. Lichen survival in a burned oak savanna. Michigan Botanist 22:47-52.

799. Whisenant, S. G.

1990. Postfire population dynamics of Bromus japonicus. American Midland Naturalist 123:301-08.

800. White, A. S.

1983. The effects of thirteen years of annual prescribed burning on a Quercus ellipsoidalis community in Minnesota. Ecology 64:1081-85.
801. White, A. S.

1986. Prescribed burning for oak savanna restoration in central Minnesota. U.S. Department of Agriculture Forest Service Research Paper NC266. $12 \mathrm{pp}$.

802. White, A. S., J. E. Cook, and J. M. Vose.

1991. Effects of fire and stand structure on grass phenology in a ponderosa pine forest. American Journal of Botany 126:269-78.

803. White, E. M. and F. R. Gartner.

1975. Immediate effects of prairie fire on the soil nitrate, ammonium, available phosphorus, and total N contents. Proceedings of the South Dakota Academy of Science 54:188-93.

804. Whitehead, C. J. and C. A. McConnel.

1979. Controlled burning studies in old fields. Tennessee Wildlife Research Agency Technical Report 79-11. $31 \mathrm{pp}$

805. Whitmore, R. C.

1981. Structural characteristics of grasshopper sparrow habitat. Journal of Wildlife Management 45:811-14.

806. Whitney, G. G.

1986. Relation of Michigan's presettlement pine forests to substrate and disturbance history. Ecology 67(6):1548-59.

807. Whitney, G. G.

1987. An ecological history of the Great Lakes forest of Michigan. Journal of Ecology 75:667-84.

808. Wicklow, D. T

1973. Microfungal populations in surface soils of manipulated prairie stands. Ecology 54:1302-10.

809. Wicklow, D. T.

1979. Factors influencing patterns of ascomycete sporulation following simulated burning of prairie soils. Soil Biology and Biochemistry 10:533-36.

810. Williams, C. E. and W. C. Johnson.

1990. Age structure and the maintenance of Pinus pungens in pine oak forests of southwestern Virginia (USA). American Midland Naturalist 124(1):130-41.

811. Williamson, G. B., N. H. Fischer, D. R. Richardson, and A. De La Pena.

1989. Chemical inhibition of fire prone grasses by fire sensitive shrub, Conradina canescens. Journal of Chemical Ecology 15(5):1567-78. 
812. Willson, G. D.

1992. Morphological characteristics of smooth brome used to determine a prescribed burn date. pp. 113-16 in D. D. Smith and C. A. Jacobs, eds. Proceedings of the 12 th North American Prairie Conference. University of Northern Iowa, Cedar Falls. 218 pp.

813. Will-Wolf, S.

1991. Role of fire in maintaining oaks in mesic oak maple forests. pp. 27-33 in S. B. Laursen and J. F. DeBoe, eds. The oak resource in the upper Midwest: implications for management. University of Minnesota Extension Service, St. Paul. 309 pp.

814. Will-Wolf, S. and D. W. Roberts.

1993. Fire and succession in oak-maple upland forests: a modeling approach based on vital attributes. pp. 217-36 in J. S. Fralish, R. P McIntosh and O. L. Loucks, eds. John T. Curtis: fifty years of Wisconsin plant ecology. The Wisconsin Academy of Sciences, Arts and Letters, Madison. $339 \mathrm{pp}$.

815. Wilson, A. A. G.

1988. Width of firebreak that is necessary to stop grass fires: some field experiments. Canadian Journal of Forest Research 18(6):682-87.

816. Wilson, R. A.

1990. Reexamination of Rothermel's fire spread equations in no-wind and no-slope conditions. pp. 1-13 in U.S. Department of Agriculture Forest Service Research Paper INT-434. 13 pp.

817. Wilson, S. D. and J. M. Shay.

1990. Competition, fire, and nutrients in a mixed-grass prairie. Ecology 71(5):1959-67.

818. Wilson, S. D. and D. Tilman.

1991. Interactive effects of fertilization and disturbance on community structure and resource availability in an old-field plant community. Oecologia 88(1):61-71

819. Windisch, A. G. and R. E. Good.

1991. Fire behavior and stem survival in the New Jersey plains. Proceedings of the Tall Timbers Fire Ecology Conference 17:273-99.

820. Wink, R. L.and H. A. Wright.

1973. Effects of fire on an ashe juniper community. Journal of Range Management 26:326-29.

821. Winkler, M. G.

1985. Charcoal analysis for paleoenvironmental interpretation: a chemical assay. Quaternary Research 23:313-26.
822. Winkler, M. G

1985. Late-glacial and Holocene environmental history of south-central Wisconsin: a study of upland and wetland ecosystems. University of Wisconsin. Ph. D. Dissertation.

823. Winkler, M. G.

1988. Effect of climate on development of two Sphagnum bogs in south-central Wisconsin. Ecology 69(4):1032-43.

824. Winkler, M. G., A. M. Swain, and J. E. Kutzback.

1986. Middle Holocene dry period in the northern midwestern United States: lake levels and pollen stratigraphy. Quaternary Research 25:235-50.

825. Winter, B. M.

1984. Effects of prescribed burning on avian foraging ecology and arthropod abundance in sagebrush-grassland. Iowa State University. M. S. Thesis. 82 pp.

826. Wisconsin Department of Natural Resources.

1970. Fire: fire control and forest protection in Wisconsin. Wisconsin Department of Natural Resources, Madison. 59 pp.

827. Wood, G. E., ed.

1981. Prescribed fire and wildlife in southern forests: proceedings of a symposium. B. W. Baruch Forest Science Institute, Clemson University, Georgetown, South Carolina. $153 \mathrm{pp}$.

828. Wood, G. W.

1988. Effects of prescribed fire on deer forage and nutrients. Wildlife Society Bulletin 16(2):180-86.

829. Wood, G. W.

1988. Deer forage responses to prescribed burning in coastal lobolly pine stands: supplementary data. Clemson University Department of Forestry Forestry Bulletin 54. 13 pp.

830. Wright, H. A.

1970. A method to determine heat-caused mortality in bunchgrasses. Ecology 51:582-87.

831. Wright, H. A.

1974. Effect of fire on southern mixed prairie grasses. Journal of Range Management 27:417-19.

832. Wright, $\mathrm{H}$. A.

1974. Range burning. Journal of Range Management 27:5-11.

833. Wright, H. A. and A. W. Bailey.

1980. Fire ecology and prescribed burning in the Great Plains: a research review. U.S. Department of Agriculture Forest Service General Technical Report INT-77. 62 pp. 
834. Wright, H. A. and A. W. Bailey.

1982. Fire ecology; United States and southern Canada. John Wiley and Sons, Toronto. 501 pp.

835. Wright, S. L.

1986. Prescribed burning as a technique to manage insect pests of oak regeneration. pp. 91-6 in A. L. Koonce, ed. Prescribed burning in the Midwest: state of the art. University of Wisconsin-Stevens Point. 162 pp.

836. Wydeven, A. P.

1989. Experimental northern red oak regeneration in northeast Wisconsin. Research-Management Findings No. 21. Wisconsin Department of Natural Resources, Madison. 4 pp.

837. Zak, J. C. and D. T. Wicklow.

1978. Response of Carincolus ascomycetes to aerate stem temperatures and treatment intervals. Canadian Journal of Botany 56:2313-18.

838. Zedler, J. B. and O. L. Loucks.

1969. Differential burning response of Poa pratensis fields and Andropogon scoparius prairies in central Wisconsin. American Midland Naturalist $81: 341-52$

839. Zimmerman, G. M., H. Goetz, and P. W. Mielke.

1985. Use of an improved statistical method for group comparisons to study effects of prairie fire. Ecology 66(2):606-11.

840. Zimmerman, J. L.

1988. Breeding season habitat selection by the Henslow's sparrow (Ammodramus henslowii) in Kansas. Wilson Bulletin 100(1):17-24.

841. Zontek, F.

1966. Prescribed burning on the St. Marks National Wildlife Refuge. Proceedings Tall Timbers Fire Ecology Conference 5:195-201. 


\section{Acknowledgments}

Special thanks go to Kim Freeman and Suzanne du Vair for their assistance in capturing references into the electronic data base; to Amy Kindschi, Suzanne du Vair, and Lynn Jacobson of the Bureau of Research Technical Library for filling many article requests; and to Amy Kindschi and Suzanne $\mathrm{du}$ Vair for their expert assistance in the use of Pro-Cite software. Helpful guidance was provided by Wendy McCown, Managing Editor for the Bureau of Research. Helpful reviews of the manuscript were received from Dr. Virginia Kline, Dr. Alan Haney, Dr. Eric Kruger, Mark Martin, Barbara Bray, and two anonymous reviewers.

This project was supported in part by funds from the Federal Aid in Wildlife Restoration Act under the Pittman-Robertson project.

\section{About the Authors}

Richard A. Henderson has been a researcher with the Wisconsin DNR Wildlife and Forestry Research Group since 1984 and is currently the Terrestrial Ecologist stationed at the DNR Research Center, 1350 Femrite Drive, Monona, Wisconsin 53716. Rich has maintained an active interest in fire ecology since completion of his M.S. thesis on the effect of seasonal timing of fire on native prairie vegetation which was completed at the University of WisconsinMadison in 1981.

Sandra H. Statz is currently a graduate student of Entomology at the University of Wisconsin-Madison, where she is specializing in the taxonomy and systematics of Coleopterous insects. Sandi also maintains a general interest in the ecology and management of Wisconsin's diverse habitats.

\section{Production Credits}

Wendy M. McCown, Managing Editor Michelle E. Jesko, Layout and Production 


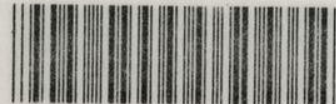

INICAL BULLETINS (1988-1995) cies assemblages in ern Wisconsin streams with implications for smallmouth bass management. (1988) John Lyons, Anne M. Forbes, and Michael D. Staggs

No. 162 A compendium of 45 trout stream habitat development evaluations in Wisconsin during 1953-1985. (1988) Robert L. Hunt

No. 163 Mercury levels in walleyes from Wisconsin lakes of different water and sediment chemistry characteristics. (1989) Richard C. Lathrop, Katherine C. Noonan, Paula M. Guenther, Therese L. Brasino, and Paul W. Rasmussen

No. 164 Water quality and restoration of the lower Oconto River, Oconto County, Wisconsin. (1989) Richard A. Rost

No. 165 Population dynamics of smallmouth bass (Micropterus dolomieui) in the Galena (Fever) River and one of its tributaries. (1989) Anne M. Forbes

No. 166 Bibliography of fishery investigations on large salmonid river systems with special emphasis on the Bois Brule River, Douglas County, Wisconsin. (1989) Robert B. DuBois

No. 167 Wisconsin recreation survey-1986. (1989) Linda J. Penaloza

No. 168 A postglacial vegetational history of Sauk County and Caledonia Township, Columbia County, South Central Wisconsin. (1990) Kenneth I. Lange

No. 169 A review of fisheries habitat improvement projects in warmwater streams, with recommendations for Wisconsin. (1990) John Lyons and Cheryl Courtney

No. 170 Ecosystem responses to growth and control of submerged macrophytes: a literature review. (1990) Sandy Engel

No. 171 The sport fishery for, and selected population characteristics of, smallmouth bass in Pallette Lake, Wisconsin, 1956-1984. (1990) Michael H. Hoff and Steven L. Serns

No. 172 Restoration of canvasback migrational staging habitat in Wisconsin: a research plan with implications for shallow lake management. (1991) Rich Kahl

No. 173 Evaluation of a catch and release fishery for brown trout regulated by an unprotected slot length. (1991) Robert L. Hunt
No. 174 Boating pressure on Wisconsin's lakes and rivers: results of the 1989-1990 Wisconsin recreational boating study, phase 1. (1991) Linda J. Penaloza

No. 175 Distribution and relative abundance of fishes in Wisconsin. VIII. Summary report. (1992) Don Fago

No. 176 Electric fencing for duck and pheasant production in Wisconsin. (1992) Ronald C. Gatti, James O. Evrard, and William J. Vander Zouwen

No. 177 Population biology and management of the walleye in western Lake Superior. (1992) Stephen T. Schram, Terry L. Margenau, and William $\mathrm{H}$. Blust

No. 178 A survey of the aquatic insects of the Lower Wisconsin River, 1985-1986, with notes on distribution and habitat. (1992) Richard A. Lillie and William L. Hilsenhoff

No. 179 Evaluation of trout habitat improvement structures in three high-gradient streams in Wisconsin. (1992) Robert L. Hunt

No. 180 Boater attitudes and experiences: results of the 1989-1990 Wisconsin recreational boating study, phase 2 . (1992) Linda J. Penaloza

No. 181 The fishery of the Yahara lakes. (1992) Richard C. Lathrop, Susan B. Nehls, Clifford L. Brynildson, and Karen R. Plass

No. 182 Aquatic macrophyte ecology in the Upper Winnebago Pool Lakes, Wisconsin. (1993) Rich Kahl

No. 183 The fisher in Wisconsin. (1993) Bruce E. Kohn, Neil F. Payne, James E. Ashbrenner, and William A. Creed

No. 184 Chemical and biotic characteristics of two low-alkalinity lakes in northern Wisconsin: relation to atmospheric deposition. (1993) Katherine E. Webster, Joseph M. Eilers, James G. Wiener, Gary E. Glass, Paul J. Garrison, and Mark D. Johnson

No. 185 Aquatic insects of the Bois Brule river system, Wisconsin. (1993) Robert B. DuBois

No. 186 Restoring Rice Lake at Milltown, Wisconsin. (1994) Sandy Engel and Stanley A. Nichols

No. 187 Bibliography of fire effects and related literature applicable to the ecosystems and species of Wisconsin. (1995) Richard A. Henderson and Sandra H. Statz 